Aus dem Department für Nutztierwissenschaften

Lehrstuhl für Produktionssysteme der Nutztiere

\title{
Einfluss des Weideangebotes auf Wohlbefinden, Gesundheit und Leistung von Milchkühen
}

\author{
Dissertation \\ zur Erlangung des Doktorgrades \\ der Fakultät für Agrarwissenschaften \\ der Georg-August-Universität Göttingen
}

vorgelegt von

Linda Armbrecht

geboren in Hildesheim

Göttingen, Mai 2017 
D 7

1. Referent: Prof. Dr. Dr. Matthias Gauly

2. Korreferentin: Prof. Dr. Imke Traulsen

Tag der mündlichen Prüfung: 13. Juli 2017 


\section{Inhaltsverzeichnis}

Zusammenfassung

Summary

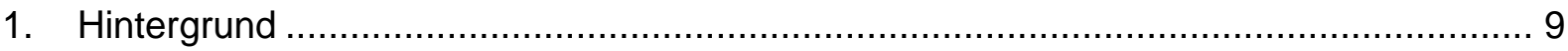

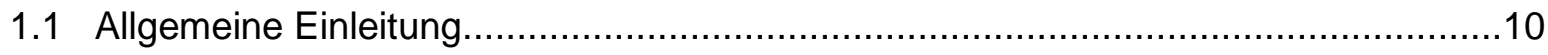

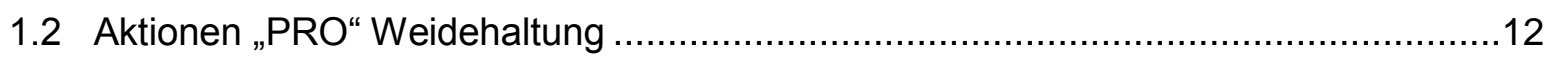

1.3 Stärken und Schwächen der Weidehaltung .......................................................13

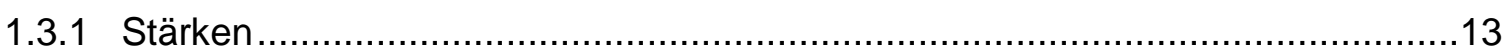

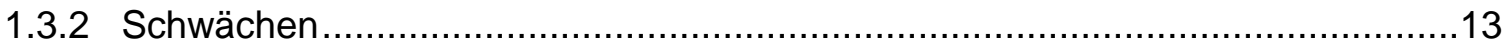

1.4 Artgemäße Verhaltensweisen auf der Weide .................................................15

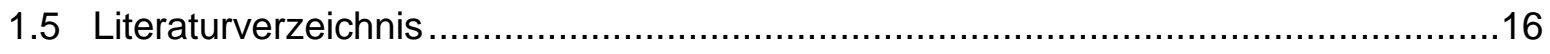

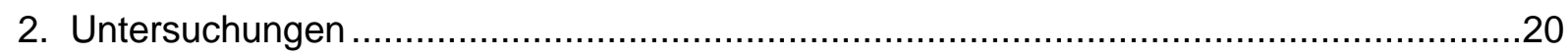

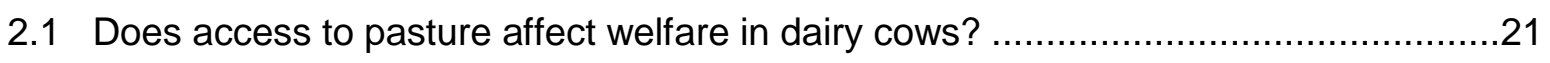

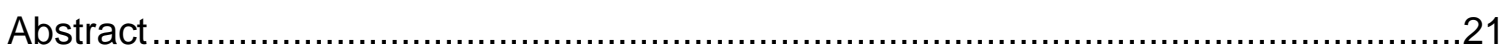

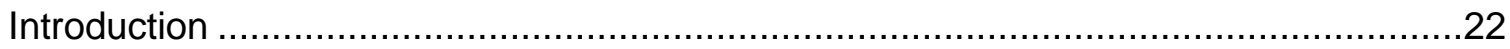

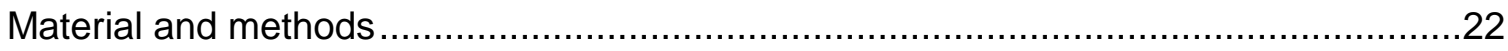

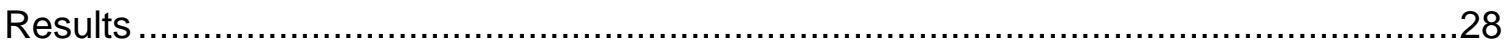

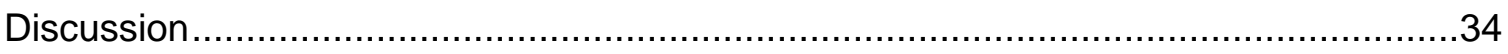

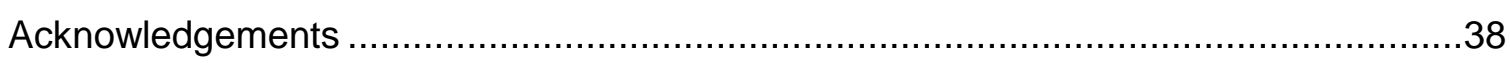

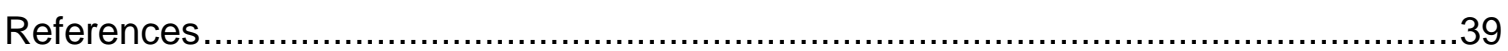

2.2 Does access to pasture affect claw conformation and health in dairy cows? .............43

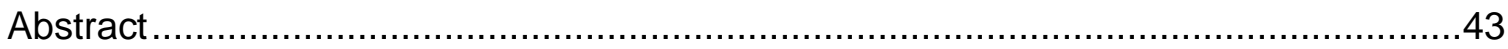

Introduction

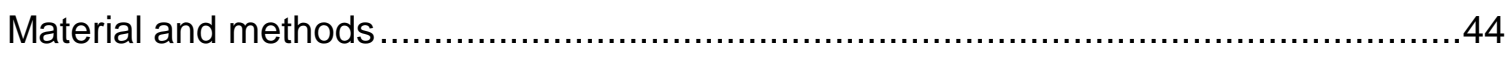

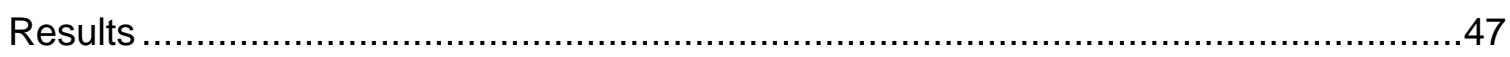

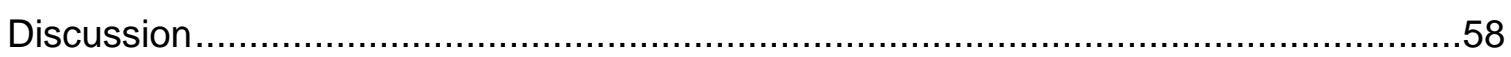

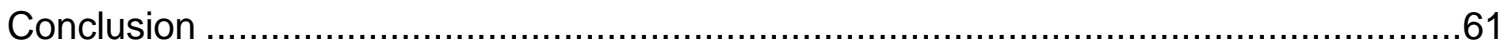

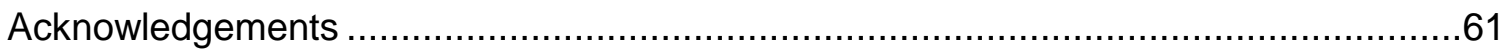

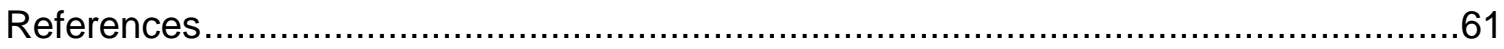

2.3 Einfluss von Stall- und Weidehaltung auf ausgewählte Tiergesundheits- und

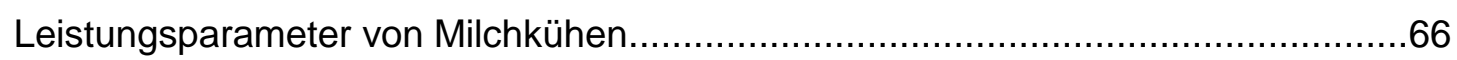

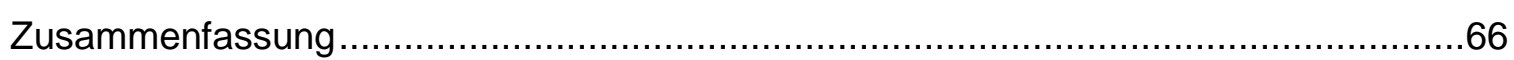

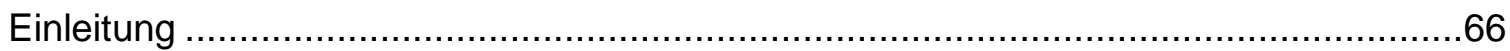

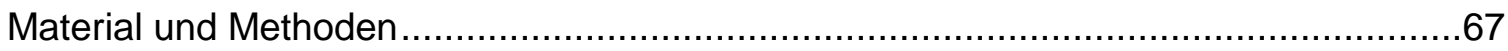

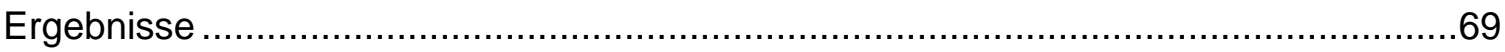

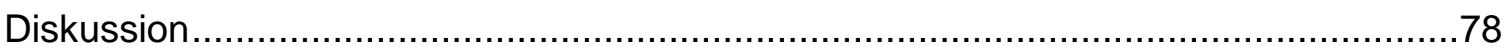

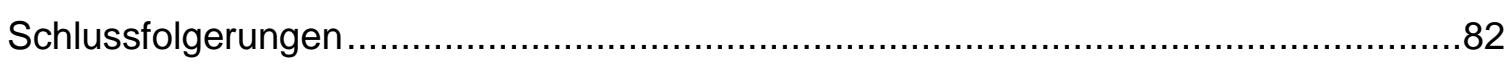




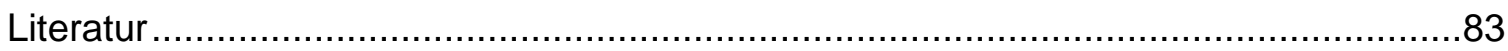

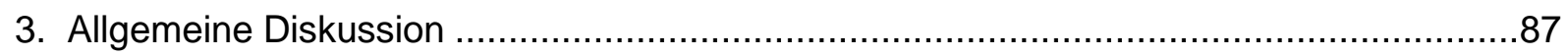

3.1 Effekte des Weidezugangs auf das Tierwohl und die Tiergesundheit.......................88

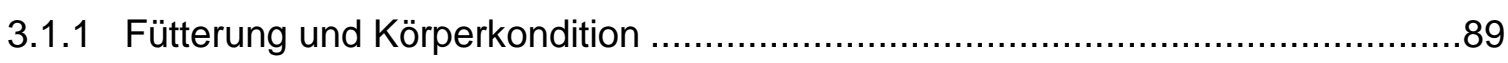

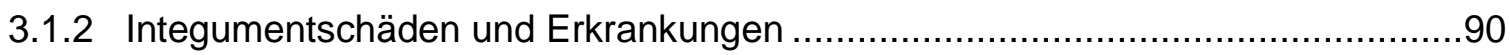

3.2 Effekte des Weidezugangs auf Klauenparameter..................................................

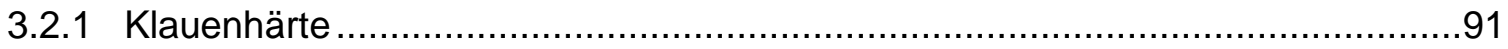

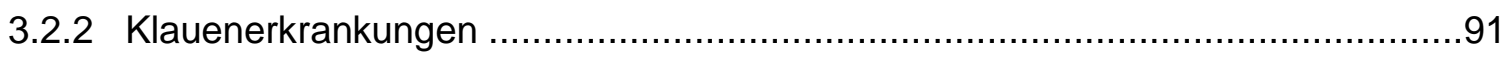

3.3 Effekte des Weidezugangs auf die Milchleistung und -inhaltsstoffe.........................93

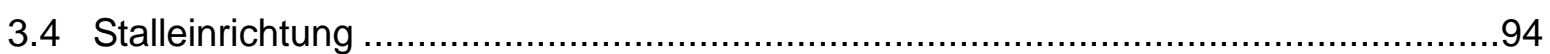

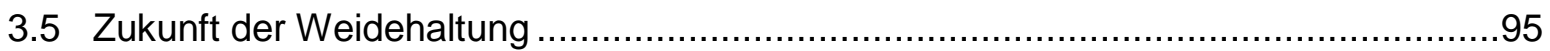

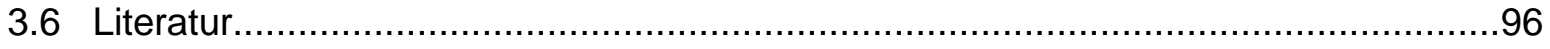

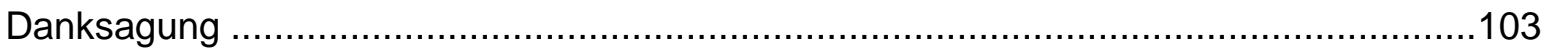

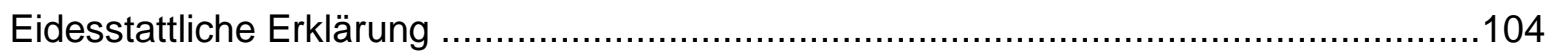

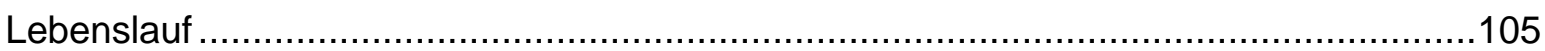




\section{Abkürzungsverzeichnis}

\begin{tabular}{|c|c|}
\hline WQP & Welfare Quality® Protocol \\
\hline WQ & Welfare Quality \\
\hline QBA & Qualitative Behavioral Assessment \\
\hline BCS & Body Condition Score \\
\hline REM & Rapid Eye Movement \\
\hline DLG & Deutsche Landwirtschafts-Gesellschaft \\
\hline ECM & Energy Corrected Milk Yield (=Energie korrigierte Milchmenge) \\
\hline PSE & Pooled Standard Error \\
\hline LS Means & Least Squares Means \\
\hline SE & Standard Error \\
\hline DIM & Days in Milk \\
\hline DD & Dermatitis Digitalis \\
\hline DID & Dermatitis Interdigitalis \\
\hline LI & Limax (engl. Interdigital Hyperplasia = IH) \\
\hline BF & Ballenhornfäule (engl. Heel Horn Erosion = HHE) \\
\hline $\mathrm{RE}$ & Klauenrehe (engl. Sole Haemorrhage = SH) \\
\hline WLD & Weiße-Linie-Defekt (engl. White Line Disease = WLD) \\
\hline WL & Wandläsion (engl. Wall Lesion = WL) \\
\hline DS & Doppelte Sohle (engl. Double Sole = DS) \\
\hline $\mathrm{PH}$ & Phlegmone (engl. Interdigital Phlegmon = PH) \\
\hline SG & Sohlengeschwür (engl. Sole Ulcer = SU) \\
\hline RSG & Rusterholzsches Sohlengeschwür (engl. Rusterholz Sole Ulcer = RSU) \\
\hline SSG & Sohlenspitzengeschwür (engl. Toe Ulcer = TU) \\
\hline STG & Steingalle/ Druckstelle (engl. Punctual Discoloration = PD) \\
\hline HS & Hornspalt (engl. Horn Fissure = HF) \\
\hline FEQ & Fett-Eiweiß-Quotient \\
\hline TLV & Tier-Liegeplatz-Verhältnis \\
\hline TFV & Tier-Fressplatz-Verhältnis \\
\hline SAM & Systemanalyse Milch \\
\hline TMR & Totale Mischration (engl. Total Mixed Ration) \\
\hline
\end{tabular}




\section{Tabellenverzeichnis}

Table 2.1.1 Data collected for the assessment of the overall score of dairy cows using the Welfare Quality ${ }^{\circledR}$ protocol.....

Table 2.1.2 Characteristics (herd size, energy corrected milk yield (ECM), protein and fat percentage, cubicle design) of 61 dairy farms with $>10$ hours (G1), 6 to 10 hours (G2), < 6 hours of pasture access/day (G3) or without pasture access (G4).

Table 2.1.3 Overall Welfare Quality ${ }^{\circledR}$ classification at the end of the pasture (visit 1, summer 2014) and barn season (visit 2, winter 2014/15) for dairy farms with > 10 hours (Group 1), 6 to 10 hours (Group 2), $<6$ hours of pasture access/day (Group 3) or without pasture access (Group 4)

Table 2.1.4 Results of the Welfare Quality ${ }^{\circledR}$ assessments at the level of principles and criteria at the end of the pasture (visit 1, summer 2014) and barn season (visit 2, winter 14/15) for dairy farms with > 10 hours (G1), 6 to 10 hours (G2), $<6$ hours of pasture access/day (G3) or without pasture access (G4)

Table 2.1.5 Selected results of Welfare Quality ${ }^{\circledR}$ assessments at indicator level at the end of the pasture (visit 1, summer 2014) and barn season (visit 2, winter 14/15) of dairy farms with $>10$ hours (G1), 6 - 10 hours (G2), $<6$ hours of pasture access/day (G3) or without pasture access (G4) .32

Table 2.2.1 Keycode for claw assessment of German Agricultural Society (DLG) 48

Table 2.2.2 Characteristics (herd size, energy corrected milk yield (ECM), protein content and fat content, cubicle design) of 20 dairy farms with $>10$ hours (G1), 6 to 10 hours (G2), < 6 hours of pasture access/day (G3) or without pasture access (G4) of three years (2012-2015)

Table 2.2.3 Claw length (hind claws) and hardness (Shore-D of right and left hind claw) at the end of the pasture (summer) and barn season (winter) of dairy farms with $>10$ hours (G1), 6 to 10 hours (G2), < 6 hours of pasture access/day (G3) or without pasture access (G4), for 12 animals per farm/ farm visit.

Table 2.2.4 Mean cumulative score at the end of the pasture (summer) and barn season (winter) of dairy farms with $>10$ hours (G1), 6 to 10 hours (G2), $<6$ hours of pasture access/day (G3) or without pasture access (G4), for 12 animals per farm/ farm visit.

Table 2.2.5 Spearman correlations of claw hardness, length, scores of the most frequent diseases. 
Tabelle 2.3.1 Saisonale Verteilung (in \%) der Abkalbungen in 61 Milchviehbetrieben mit $>10$ Stunden (G1), 6 bis 10 Stunden (G2), < 6 Stunden Weidegang/ Tag (G3) oder ohne Weidezugang (G4).

Tabelle 2.3.2 Betriebscharakteristika im Durchschnitt der Jahre 2012-2015 von 61

Milchviehbetrieben mit > 10 Stunden (G1), 6 bis 10 Stunden (G2),

< 6 Stunden Weidegang/ Tag (G3) oder ohne Weidezugang (G4) .71

Tabelle 2.3.3 Abgangsgründe (in \%) im Durchschnitt der Jahre 2012-2015 von 61 Milchviehbetrieben mit > 10 Stunden (G1), 6 bis 10 Stunden (G2), < 6 Stunden Weidegang/ Tag (G3) oder ohne Weidezugang (G4) .72

Tabelle 2.3.4 Pearson-Korrelationen zwischen Leistungs- und Gesundheitsparametern von 61 Milchviehbetrieben 


\section{Abbildungsverzeichnis}

Figure 2.2.1 Measuring points for hardness at the medial (1-3) and lateral claw (4-7) on sole horn and abaxial wall (8) as well as measuring points for length on dorsal wall of the medial claw

Figure 2.2.2 Prevalence of diseased cows at the end of the pasture (summer) and barn season (winter) of dairy farms with $>10$ hours (Group 1), 6 to 10 hours (Group 2), $<6$ hours of pasture access/day (Group 3) or without pasture access (Group 4).

Figure 2.2.3 Prevalence of claw diseases of different severity (none, mild, moderate, severe) at the end of the pasture (summer) and barn season (winter) in farms with > 10 hours (Group 1), 6 to 10 hours (Group 2), < 6 hours of pasture access/day (Group 3) or without pasture access (Group 4), for 12 animals per farm/ farm visit

Abbildung 2.3.1 Entwicklung der Parameter ECM, Fett, Eiweiß, Zellzahl, Harnstoff und FettEiweiß-Quotient für die Jahre 2012 bis 2015 im Jahresverlauf von 61 Milchviehbetrieben mit > 10 Stunden (G1), 6 bis 10 Stunden (G2), $<6$ Stunden Weidegang/ Tag (G3) oder ohne Weidezugang (G4) .74 


\section{Zusammenfassung}

\section{Linda Armbrecht „Einfluss des Weideangebotes auf Wohlbefinden, Gesundheit und Leistung von Milchkühen"}

Der Anteil an Milchkühen, welche Zugang zu einer Weide erhalten, ist in den letzten Jahren stark zurückgegangen und in Europa zwischen 2008 und 2012 bereits um 17 Prozentpunkte, auf nur noch $35 \%$, gesunken. In Deutschland wird momentan davon ausgegangen, dass etwa 15 bis 30\% der Milchkühe Zugang zur Weide bekommen. Jedoch wird insbesondere die Weidehaltung bei Milchkühen vom Verbraucher sehr positiv wahrgenommen. Dies ist einer der Hauptgründe, warum die Milchviehhaltung im Vergleich zu anderen Nutztierarten häufiger als tiergerecht angesehen wird.

Ziel der vorliegenden Arbeit war es daher die Weidehaltung mit ganzjähriger Stallhaltung zu vergleichen und zu überprüfen, ob sich die beiden Systeme im Hinblick auf Wohlbefinden, Tiergesundheit und Leistung unterscheiden. Durch Erfassung von Maßen und Ausstattungen der Liegeboxen wurde dabei auch der Effekt von Hoch- und Tiefboxen beurteilt. Insgesamt sind Daten von 61 Milchviehbetrieben in Niedersachsen in die Untersuchungen eingeflossen. Die Betriebe wurden, Anhand der Verfügbarkeit und Dauer des täglichen Weidegangs in den Sommermonaten, in vier Gruppen eingeteilt: Gruppe 1 (G1) mit $>10$ Std. Weidegang/ Tag, Gruppe 2 (G2) mit 6 bis 10 Std. Weidegang/ Tag, Gruppe 3 (G3) mit < 6 Std. Weidegang/ Tag und Gruppe 4 (G4) mit ganzjähriger Stallhaltung. Weidegang wurde in G1, G2 und G3 für mindestens 120 Tage im Jahr angeboten. Zur Gruppe G4 gehörten 16 Betriebe, zu den anderen Gruppen jeweils 15 Betriebe. Alle Betriebe hielten Kühe der Rasse Holstein-Friesian oder Red-Holstein in Liegeboxenlaufställen.

Gegenstand der ersten Untersuchung (Kapitel 2.1) war der Vergleich der genannten 61 Milchviehbetriebe, innerhalb der entsprechenden Gruppen, mit Hilfe des Welfare Quality ${ }^{\circledR}$ Protokolls für Rinder (WELFARE QUALITY®, 2012). Das Protokoll beinhaltet unterschiedliche Bewertungskategorien mit 32 tier-, management- und ressourcenbezogenen Indikatoren. Aus diesen Indikatoren wurden zunächst Kriterien und Grundsätze aggregiert und daraus wiederum eine Gesamtbewertung des Betriebes hinsichtlich des Tierwohls erstellt. Jeder Betrieb wurde im Abstand von einem halben Jahr zweimal untersucht. Der erste Besuch fand zum Ende der Weidesaison 2014 und der zweite Besuch zum Ende der Wintersaison 2015 statt. Beide Betriebsbesuche im Sommer und Winter zusammengefasst zeigten, dass in G1 und G2 jeweils $43 \%$ der Betriebe als "verbessert" und $57 \%$ in der schlechteren Kategorie "akzeptabel" eingestuft wurden. In G3 erreichten 50\% die Kategorie "verbessert" und $50 \%$ die Kategorie "akzeptabel". In G4 wurden nur 38\% als "verbessert" und $63 \%$ als "akzeptabel" eingestuft. In die beste Welfare Quality ${ }^{\circledR}$ Kategorie "exzellent" sowie in die schlechteste 
Kategorie „nicht klassifiziert", wurde keiner der 61 Betriebe eingestuft. Das Prinzip „Gute Fütterung“ unterschied sich nicht signifikant zwischen den vier Gruppen $(P>0,05)$, wohingegen das zugehörige Kriterium „Abwesenheit von Hunger" Unterschiede zwischen den Besuchszeitpunkten zeigte. Alle Gruppen wurden bei diesem Kriterium in den Sommermonaten schlechter als in den Wintermonaten bewertet $(P<0,05)$. Die deutlichsten Unterschiede, zwischen den Bewertungen der Körperkondition in Sommer und Winter, wurden in den Gruppen mit Weidezugang beobachtet. Die Gruppen mit Weidezugang bekamen wiederum in den Sommermonaten bessere Bewertungen als G4 für das Prinzip „Gute Haltung“ $(P<0,05)$. Diese Unterschiede konnten in den Wintermonaten jedoch nicht mehr gezeigt werden $(P>0,05)$. $G 1$ und $G 2$ erhielten in beiden Betriebsbesuchen die besten Bewertungen für das Prinzip "Gute Gesundheit", einschließlich der Indikatoren "haarlose Stellen" und „Läsionen und Schwellungen“ $(P<0,05)$. Das Prinzip „Artgemäßes Verhalten“ unterschied sich nicht zwischen den vier Gruppen $(P>0,05)$. Diese Untersuchung zeigte durch den Zugang zur Weide, positive Effekte für verschiedene Indikatoren, wobei die meisten Effekte aber nicht mehr am Ende der Stallsaison nachgewiesen werden konnten.

Die zweite Untersuchung (Kapitel 2.2) verglich die Klauengesundheit und Klauenbeschaffenheit von Einzeltieren der vier Weidegruppen. Von den 61 Betrieben wurden für diese Klauenuntersuchungen 20 Betriebe ausgewählt, so dass in jeder der vier Gruppen jeweils fünf Betriebe untersucht wurden. Auf den Betrieben wurden jeweils 12 Tiere, also insgesamt 240 Tiere, nach der Weide- und nach der Stallsaison beurteilt. An den beiden hinteren Klauen wurde die Klauenhärte mit einem Shore-D Messgerät erfasst. Die Messungen erfolgten an zuvor definierten Messpunkten an Innen- und Außenklaue, Sohlenfläche und abaxialem Wandhorn. Zudem wurde die Länge der hinteren Innenklauen vermessen und Klauenerkrankungen anhand des DLG-Schlüssels an allen vier Klauen beurteilt. Dabei wurden folgende Erkrankungen mit den Schweregraden 1 bis 3 erfasst: Dermatitis Digitalis (DD), Dermatitis Interdigitalis (DID), Limax (LI), Ballenhornfäule (BF), Klauenrehe (RE), Weiße-Linie-Defekt (WLD), Wandläsion (WL), Doppelte Sohle (DS), Phlegmone (PH), Sohlengeschwür (SG), Rusterholzsches Sohlengeschwür (RSG), Sohlenspitzengeschwür (SSG), Steingalle/ Druckstelle (STG) und Hornspalt (HS). Es konnten keine signifikanten Unterschiede zwischen den Gruppen oder den Besuchszeitpunkten für die Klauenlänge und für die Sohlenhärte festgestellt werden $(P>0,05)$. Die Härte des Wandhorns zeigte jedoch deutliche Unterschiede zwischen den Gruppen $(P<0,05)$. G2 und G4 hatten die höchsten Shore-D Werte des Wandhorns. Alle drei Weidegruppen zeigten nach der Weideperiode niedrigere WLD- $(P<0,05)$ und BFPrävalenzen $(P<0,01)$ als nach der Stallperiode. Sohlengeschwüre (SG, RSG, SSG) zeigten für G2 und $G 4$ nach den Sommermonaten erhöhte Prävalenzen $(P<0,01)$, bei $G 1$ und $G 3$ unterschieden sich die Befunde der Sohlengeschwüre nicht zwischen den Besuchen $(P>0,05)$. Korrelationen zwischen einer erhöhten Klauenhärte und geringeren Krankheits- 
Scores (Prävalenz * Schweregrad) konnten für die Erkrankungen SG, WLD, RE, BF und LI festgestellt werden. In G4 zeigten 50\% aller DD erkrankten Klauen den höchsten Schweregrad, verglichen mit den anderen Gruppen, in denen maximal 25\% der DD erkrankten Klauen den höchsten Schweregrad zeigten. Insgesamt konnte herausgestellt werden, dass Weidezugang für die Tiere positive Effekte auf die Klauengesundheit hatte, insbesondere für Erkrankungen wie DD, BF und WLD, die vermehrt in feuchter Umgebung auftreten.

Die dritte Untersuchung (Kapitel 2.3) zeigte, ob die Weidehaltung nicht nur zum Gesundheitsstatus, sondern auch zur Leistung der Milchkühe beitragen kann und wie viele Weidestunden pro Tag dafür nötig wären. Ebenfalls wurden hier die Einflüsse von LiegeboxenMaßen und -ausstattungen auf Leistungsparameter und Tiergesundheit untersucht. Die Leistungsparameter von 59 der 61 Betriebe wurden über die monatlichen Daten der Milchleistungsprüfungen aus den Jahren 2012 bis 2015 ermittelt. Die Gruppen G1 und G2, mit mehr als sechs Stunden Weide pro Tag, zeigten im dreijährigen Durchschnitt eine ca. $1000 \mathrm{~kg}$ geringere Milchmenge als G4 mit ganzjähriger Stallhaltung und als G3 mit weniger als 6 Weidestunden $(P<0,05)$. Mit zunehmender Anzahl an Weidestunden wurden weniger Tiere mit leichten Lahmheiten und haarlosen Stellen beobachtet $(P<0,01)$. G4 ohne Weidehaltung zeigte höhere Abgangsraten als $G 2(P<0,05)$ und mehr Tiere mit schweren Lahmheiten $(P<0,05)$, als alle drei Gruppen mit Weidehaltung. Ein Rückgang des Fett- und Eiweißgehaltes in den Sommermonaten zeigte sich gleichermaßen über alle vier Gruppen. Im Mittel der Jahre 2012 bis 2015 konnte außerdem in den Sommermonaten ein Anstieg der Zellzahlen für G2, G3 und G4 sowie ein Anstieg des Harnstoffgehaltes für G1 und G2 festgestellt werden. Zu wenig Fressplätze (pro Tier weniger als ein Fressplatz) im Stall sowie zu wenig Liegeboxen (pro Tier weniger als eine Liegebox) und den Tieren nicht ausreichend angepasste Maße der Liegeboxen, zeigten negative Einflüsse auf mehrere Leistungs- und Gesundheitsparameter. So wurden bei zu wenig Liegeplätzen im Stall höhere Abgangsraten $(P<0,01)$, höhere Zellzahlen $(P<0,01)$ und mehr Tiere mit einem Fett-Eiweiß-Quotienten $<1$ $(P<0,05)$ beobachtet. Betriebe mit zu wenig Fressplätzen zeigten geringere Eiweißwerte $(P<0,01)$ und höhere Harnstoffwerte $(P<0,05)$. Waren die Maße der Boxen nicht an die Tiere angepasst, so zeigten sich mehr Läsionen $(P<0,01)$ und eine leichte Tendenz zu einer kürzeren Nutzungsdauer $(P<0,1)$. Tiefboxen zeigten für die Indikatoren „schwer lahm“ $(P<0,05)$, „haarlose Stellen“ $(P<0,01)$ und tendenziell auch für "Läsionen und Schwellungen“ $(P<0,1)$ signifikant bessere Bewertungen als Hochboxen. Insgesamt wurden Vorteile der Weidehaltung für mehrere gesundheitliche Parameter festgestellt, jedoch konnten bei den Leistungsparametern die Tiere mit ganzjähriger Stallhaltung höhere Milchleistungen und im Jahresverlauf konstantere Ergebnisse für den Fettgehalt der Milch, dem Anteil der Herde mit einem $F E Q<1$ und für die Harnstoffgehalte zeigen. 
Zusammenfassend konnte anhand der vorliegenden Untersuchungen gezeigt werden, dass die Weidehaltung Vorteile für das Wohlbefinden der Tiere und für die Gesundheit haben kann. Zwischen den Gruppen mit Weidehaltung variierten die Ergebnisse jedoch je nach Parameter, so dass kein eindeutiges Ergebnis über eine optimale Anzahl der Weidestunden festgestellt werden konnte. Insbesondere in der Körperkondition zeigten die Weidebetriebe auch Schwächen, da viele Tiere während der Weidesaison einen zu geringen Body Condition Score aufwiesen. Auch in der Leistung der Tiere konnten die Betriebe mit ganzjähriger Stallhaltung höhere Milchleistungen erzielen als die weidehaltenden Betriebe. Es ist davon auszugehen, dass insbesondere hochleistende Milchkuhrassen ein sehr gut abgestimmtes Weidemanagement benötigen, um sich an die Variabilität des Futterangebotes anzupassen. Ist das der Fall, haben sie aber auf der Weide sehr gute Bedingungen um sich selbst gesund zu erhalten und die körperliche Fitness zu steigern bzw. auch noch in höherem Alter beizubehalten. Diesen Untersuchungen zu Folge konnte ein positiver Einfluss auf das Wohlbefinden und die Gesundheit der Tiere während der Weidesaison gezeigt werden, nach den Wintermonaten ohne Weidezugang konnten diese Einflüsse jedoch nicht mehr festgestellt werden. Unabhängig von der Gruppeneinteilung der Betriebe konnten deutliche Unterschiede zwischen Hoch- und Tiefboxen bzw. den Tier-Liegeplatz- und Tier-Fressplatz-Verhältnissen festgestellt werden. Parameter wie Liegeboxenbeschaffenheit, Liegeboxenmaße, Management in allgemeiner Tiergesundheit und Klauengesundheit haben demnach häufig mehr Einfluss auf die Tiere, als die Entscheidung ob die Tiere Weidezugang erhalten oder nicht. 


\section{Summary}

\section{Linda Armbrecht „Effect of pasture access on welfare, health and performance of dairy cows"}

The number of dairy cows with pasture access decreased considerably in the last years, especially in Europe where it declined between 2008 and 2012 by 17 percentage points to only $35 \%$. In Germany, it must be assumed that approximately 15 to $30 \%$ of dairy cows get pasture access. However, the access to pasture for dairy cows is perceived very positively by the consumer. That is one of the main reasons why dairy farming is considered more often humane, compared to other livestock breeds.

The aim of the present study was to compare dairy farming with pasture access and yearround indoor housing and to investigate whether these two systems differ regarding welfare, health and performance of the cows. In assessing dimensions and design of cubicles, the effect of cubicles with rubber mats or deep bedded cubicles was evaluated. Overall data of 61 dairy farms in Lower Saxony (Germany) were included in this study. The farms were grouped by their intensity of pasture access during the summer months into: group 1 (G1) $>10$ hours pasture access per day, group 2 (G2) 6 - 10 hours, group 3 (G3) $<6$ hours and group 4 (G4) without access to pasture. Pasture was provided for at least 120 days in G1, G2 and G3. G4 included 16 farms, the other three groups included 15 farms, respectively. All farms kept Holstein-Friesian or Red-Holstein breed in free stall barns with cubicles.

The subject of the first investigation (Kapitel 2.1) was the comparison of these 61 dairy farms within their groups, using the Welfare Quality ${ }^{\circledR}$ Protocol for dairy cattle (WELFARE QUALITY ${ }^{\circledR}$, 2012). The protocol includes different assessment categories with 32 animal-, managementand resource-related indicators. Out of these indicators initially criteria and principles were aggregated and then again, an overall welfare assessment of a farm was calculated. Each farm was visited twice with a distance of half a year. First investigation took place at the end of the pasture season 2014 and the second investigation at the end of the barn season 2015. Summarized both farm visits in summer and winter showed G1 and G2 with $43 \%$ of the farms in the category "enhanced" and $57 \%$ in the worse category "acceptable", respectively. In G3 $50 \%$ of the farms reached the category "enhanced" and $50 \%$ the category "acceptable". In G4 only $38 \%$ of the farms were classified as "enhanced" and $63 \%$ as "acceptable". None of the 61 farms was classified in the best Welfare Quality ${ }^{\circledR}$ category "excellent" as well as in the worst category "not classified". The principle "good feeding" differed not significantly between the four groups $(P>0.05)$, whereas the related criterion "absence of hunger" showed differences between the farm visits. All groups were rated worse in the summer compared to the winter months $(P<0.05)$ for this criterion. Considerable differences between the assessments of the 
body condition in summer and winter were noted in groups with pasture access. Groups with pasture access in turn, received better assessments than G4 for the principle "good housing" in the summer months $(P<0.05)$. Though, these differences could not be shown in the winter months $(P>0.05)$. At both farm visits $G 1$ and $G 2$ got better scores for the principle "good health", including the indicators "hairless patches" and "lesions and swellings" $(P<0.05)$. The principle "appropriate behavior" differed not between the four groups $(P>0.05)$. This study showed positive effects of several indicators due to the pasture access. However, most of these effects could no longer be shown at the end of the barn season.

The second investigation (Kapitel 2.2) compared the claw health and claw conformation of individual cows in the four groups. Out of the 61 farms, 20 farms were selected for the claw investigations, so in each group five farms were assessed, respectively. On each farm 12 animals, overall 240 animals, were assessed respectively after the pasture- and barn season. On both hind claws the claw hardness was ascertained. The measures were executed on previously defined measuring points at medial and lateral claw, on the sole horn and the abaxial wall. Furthermore, the length of the hind medial claws was measured and claw diseases by reference to a keycode of the German Agricultural Society (Deutsche Landwirtschafts-Gesellschaft, DLG) were assessed on each of the four claws. This assessment scheme contains different degrees of severity from 1 to 3 of the following diseases: Dermatitis digitalis (DD), Dermatitis interdigitalis (DID), Sole Haemorrhage (SH), Sole Ulcer (SU), Rusterholz Sole Ulcer (RSU), Toe Ulcer (TU), Heel Horn Erosion (HHE), Punctual Discoloration (PD), Wall Lesion (WL), Double Sole (DS), White Line Disease (WLD), Interdigital Hyperplasia (IH), Interdigital Phlegmon (PH) and Horn Fissure (HF). No significant differences could be shown between the groups or the farm visits for claw length and sole hardness $(P>0.05)$. However, the hardness of wall horn, showed obvious differences between the groups $(P<0.05)$. G2 and G4 had the highest Shore-D values of the wall horn. All three pasture groups showed lower WLD- $(P<0.05)$ and HHE-prevalences $(P<0.01)$ after the pasture period than after the barn period. Sole ulcers (SU, RSU, TU) showed higher prevalences in $G 2$ and $G 4$ after the summer months $(P<0.01)$, in $G 1$ and $G 3$ the results of sole ulcers did not differ between the farm visits $(P>0.05)$. Correlations between a high claw hardness and low disease-scores (prevalence * severity level) could be ascertained for the diseases SU, WLD, SH, HHE and IH. In G4 approximately $50 \%$ of the DD affected claws were scored as severe compared to the other groups with max. $25 \%$ of severe DD affected claws. Overall it could be shown that pasture access had positive effects for the claw health, especially for claw diseases related to moist environments like DD, HHE and WLD.

Third investigation (Kapitel 2.3) showed whether pasture access could not only contribute to health status, but also to performance of the dairy cows and how many hours with pasture 
access per day were required. Moreover, effects of cubicle dimensions and -design on performance parameters and animal health were assessed. On 59 of the 61 farms performance parameters were ascertained by the monthly data of milk yield recordings in the years 2012 to 2015. Over this three-year period G1 and G2 with more than six hours on pasture per day, averaged $1000 \mathrm{~kg}$ lower milk yield than G4 with year-round indoor housing and than G3 with less than six hours pasture access $(P<0.05)$. With increasing hours of pasture access, less animals with light lameness and hairless patches were observed $(P<0.01)$. G4 without pasture access showed higher culling rates than $G 2(P<0.05)$ and more cows with a severe lameness $(P<0.05)$ than all three groups with pasture access. Over all four groups there was an equal decrease of fat- and protein content in the summer months. Furthermore, on average of the years 2012 to 2015 an increase of the somatic cell count for G2, G3 and G4 as well as an increase of urea concentration for $\mathrm{G} 1$ and $\mathrm{G} 2$ in the summer months could be indicated. Too little feeding places (less than one feeding place per animal) in the barn as well as too little cubicles (less than one cubicle per animal) and unadapted dimensions of the cubicles, showed negative influences on several performance- and health parameters. For too little numbers of cubicles in the barn, higher culling rates $(P<0.01)$, higher somatic cell count $(P<0.01)$ and more animals with a fat/ protein ratio $<1(P<0.05)$ were indicated. Farms with too little feeding places showed lower protein contents $(P<0.01)$ and higher urea concentrations $(P<0.05)$. If dimensions of the cubicles were not adapted for the animals, more lesions $(P<0.01)$ and a light tendency for shorter lifespan $(P<0.1)$ could be ascertained. Deep-bedded cubicles showed significant better assessments than cubicles with rubber mats for the indicators "severely lame" $(P<0.05)$, "hairless patches" $(P<0.01)$ and with a tendency for "lesions and swellings" $(P<0.1)$. Overall, pasture access showed advantages for health parameters, however performance parameters on farms with no access to pasture showed a higher milk yield and more consistent results, during the course of the year, for the milk fat content, the percentage of the herd with a fat/ protein ratio $<1$ and for the urea concentration.

Summarizing, it could be indicated by means of this study that pasture access could have benefits for animal welfare and health. Nevertheless, between the groups with pasture access this varied depending on the individual parameter, so that there could not be shown a distinct result about an optimal number of hours with access to pasture. Especially regarding the body condition, farms with pasture access showed weaknesses, due to many cows with a poor body condition during the pasture season. Additionally, farms with year-round indoor housing reached a higher milk yield than farms with pasture access. It must be assumed that particularly high yielding dairy cows need a very well adjusted pasture management, to adapt the variability of food supply. In this case, they have ideal conditions to keep their selves healthy and to improve their fitness or maintained it to an older age. In the present investigation, a positive effect on welfare and health of the animals was found during the 
pasture season, though after the winter months without pasture access, these positive effects could no longer be ascertained. Independent of the pasture-group classification of the farms, obvious differences between deep-bedded cubicles and cubicles with rubber mats, respectively between animal/ feeding place ratios and animal/ cubicle ratios were indicated. Hence, parameters like cubicle design, cubicle dimensions, management of animal- and claw health, commonly have more influence on animals than the availability of pasture access. 
1. Hintergrund 


\subsection{Allgemeine Einleitung}

In Deutschland haben aktuell etwa 15 bis 30\% aller Milchkühe die Möglichkeit während der Sommermonate auf die Weide zu gehen (WEIB, 2014). Verglichen mit Nachbarländern wie Österreich und der Schweiz, wo noch etwa 68\% bzw. 80\% aller Milchkühe weiden können, ist das eine geringe Prozentzahl (LEITHOLD et al., 2011). Trotzdem ist in ganz Europa mittlerweile ein Rückgang Weidehaltung zu verzeichnen (REIJS et al., 2013; VAN DEN POL - VAN DASSELAR et al., 2015). Im Mittel über ganz Europa sank die Anzahl von Milchkühen mit Zugang zur Weide, von 52\% in 2008 zu nur noch 35\% in 2012 (REIJS et al., 2013). Begründet ist der abnehmende Weidezugang hauptsächlich durch steigende Herdengrößen, optimierte Arbeitsabläufe im Betrieb, schwierige Kompatibilität mit automatischen Melksystemen und standardisierte Fütterungssysteme. Weitere Gründe für den allgemeinen Rückgang der Weidehaltung sind aber auch hohe Pachtpreise für Grünlandflächen, bei vergleichsweise kostengünstigem Kraftfutter sowie fehlende Erfahrung und Beratung über das Management und die Flächenproduktivität der Weidehaltung (LEISEN, 2014).

In der aktuellen Diskussion um Tierwohl in der Nutztierhaltung werden Milchkühe, verglichen mit der Schweine- oder Geflügelfleischerzeugung, sehr positiv wahrgenommen. Nicht zuletzt deshalb, weil die Milchkuhhaltung vom Verbraucher häufig mit Weidehaltung in Verbindung gebracht wird und diese wiederum mit mehr Tierwohl und mehr Nachhaltigkeit (WEINRICH et al., 2014; WEIB, 2014). Nach BARTUSSEK (1999) ist deutlich gesteigertes Tierwohl auch tatsächlich auf der Weide zu erwarten, da das Tier dort am ehesten seine natürlichen Verhaltensweisen ausleben kann. Weitere internationale Untersuchungen zeigen auch auf verschiedensten Forschungsgebieten Vorteile für die Weidehaltung von Milchkühen. So waren Gesundheitsparameter, wie Mortalität, Integumentschäden (BUROW, 2012) und Mastitisprävalenzen (WASHBURN et al., 2002) für Kühe ohne Zugang zur Weide erhöht, im Vergleich zu Kühen mit Weidezugang. Auch ökonomische Vorteile von Weidehaltungssystemen, verglichen mit ganzjähriger Stallhaltung wurden nachgewiesen (HARMS, 2008). Weiterhin zeigten HERNANDEZ-MENDO et al. (2007) und Olmos et al. (2009), dass Kühe mit Weidezugang eine verbesserte Klauengesundheit und Lokomotion aufwiesen im Vergleich zu Kühen, die ganzjährig im Stall gehalten wurden.

Insbesondere die Klauengesundheit stellt nach Fertilitäts- und Mastitisproblemen die dritthäufigste Abgangsursache in der Milchviehhaltung dar (WEBER et al., 2012). Klauenerkrankungen verursachen häufig starke Schmerzen für die Tiere und beeinträchtigen dadurch auch deren Wohlbefinden (WHAY et al., 1998; RUSHEN et al., 2007). Die Lahmheitsinzidenz der Hochleistungskühe liegt bei durchschnittlich 20 bis $25 \%$ pro Jahr (MüLLING und GREENOUGH, 2006). Stallbauliche Gegebenheiten wie rutschige oder abrasive Bodenbeläge (SOMERS et al., 2003; TELEZHENKO und BERGSTEN, 2005), harte Liegeflächen in den Boxen 
(KANSWOHL und SANFTLEBEN, 2006; ZÄHNER et al., 2009; ITO et al., 2010) oder auch falsch dimensionierte Liegeboxen (SOGSTAD et al., 2005; DIPPEL et al., 2009) können zu vermehrten Lahmheiten führen. Diese negativen Einflussfaktoren treten nicht auf der Weide auf, wo die Tiere einen weichen Boden zur Verfügung haben, was die Klauengesundheit verbessern kann (HASKELl et al., 2006; HERnANDEZ-MENDo et al., 2007; AlgERs et al., 2009; CoRAZZIN et al., 2010).

Trotzdem die Stallhaltung der Milchkühe in den letzten Jahren deutlich tiergerechter und für den Menschen arbeitsfreundlicher geworden ist, so ist es dennoch fraglich, ob für Milchkühe, die von Natur aus Weichbodengänger sind, eine artgerechte Umgebung in einem Stall mit harten, betonierten Stallböden und einschränkenden Liegeboxen erreicht werden kann (STEINWIDDER und STARZ, 2006; KREMER, 2006). Es fehlen bisher noch umfassende Untersuchungen, über die Effekte der Weidehaltung auf das Tierwohl und die Tiergesundheit. Vorangegangene Studien erfassten häufig nur einzelne, ausgewählte Indikatoren. Für eine ganzheitliche Betriebsanalyse wurde für diese Arbeit das Welfare Quality assessment protocol (WQP; WELFARE QUALITY $\AA$, 2012) ausgewählt, welches umfangreiche ressourcen-, management- und tierbezogene Indikatoren einschließt.

Diese Dissertation untersucht den Einfluss der Weidehaltung mit unterschiedlicher Intensität auf Milchviehbetrieben in Niedersachsen. Hierbei werden (1) das Wohlbefinden und die allgemeine Gesundheit der Tiere, (2) die Klauen-Maße, die Klauen-Härte und die Klauengesundheit sowie (3) verschiedene Leistungsparameter erfasst.

Dafür wurden 61 Milchviehbetriebe mit dem WQP jeweils zum Ende der Sommer- und zum Ende der Wintersaison untersucht, mit der Fragestellung, ob die untersuchten Parameter für Betriebe mit ganzjähriger Stallhaltung und/ oder für Betriebe mit Weidehaltung positive Ergebnisse zeigen. Diese 61 Betriebe stellten außerdem Daten ihrer Milchleistungsprüfungen der Jahre 2012 bis 2015 zur Verfügung und beantworteten mehrere Fragen zur Weidehaltung in einem Fragebogen. Zusätzlich wurden die Liegeboxen bei jedem Betrieb vermessen. Aus diesen Daten in Verbindung mit den WQP-Ergebnissen wurde genauere Charakterisierungen der stallhaltenden und weidehaltenden Betriebe erstellt und miteinander verglichen. Um die Dauer zu untersuchen, die die Milchkühe auf der Weide verbringen müssen, damit positive Effekte für die Klauengesundheit erzielt werden, wurden außerdem Klauenuntersuchungen (Ende Weidesaison und Ende Wintersaison) auf 20 dieser 61 Betriebe durchgeführt. Dafür wurden Klauenlänge, Härte und Prävalenzen häufiger Klauenerkrankungen erfasst. 


\subsection{Aktionen „PRO“ Weidehaltung}

Vor dem Hintergrund des deutlichen Rückgangs der Weidehaltung von Milchvieh und einem gleichzeitigen Anstieg der ganzjährigen Stallhaltung, gibt es aber auch bereits gegenläufige Aktionen. Den Verbraucher-Wünschen entsprechend vermarkten mittlerweile mehrere Molkereien (z.B. Arla, Campina, Ammerland) ihre Milch mit der der Auszeichnung „Weidemilch“. Dabei wird nur die Milch von den Betrieben verarbeitet, die ihren Tieren für eine bestimmte Mindestdauer an Tagen/ Jahr und Stunden/ Tag Zugang zur Weide ermöglichen. Ein nennenswerter Anteil an Grundfutteraufnahme auf der Weide ist nicht vorgeschrieben.

Zudem hat das niedersächsische Ministerium für Ernährung, Landwirtschaft und Verbraucherschutz ein Projekt ins Leben gerufen, das mit Akteuren aus der Landwirtschaft, Wissenschaft und Wirtschaft ein Konzept für die Vermarktung von Produkten aus Weidehaltung erarbeitet und realisiert. Das Projekt hat das Ziel mit dem Label „Pro Weideland“ auch zukünttig noch Weidehaltung für Milchkühe zu ermöglichen und dadurch das Grünland und das Landschaftsbild in Norddeutschland zu erhalten.

Diese Dissertation wurde im Rahmen des Projekts „Systemanalyse Milch“ angefertigt, welches das niedersächsischen Ministerium für Wissenschaft und Kultur 2013 als Verbundprojekt gestartet hat. Über fünf Jahre sollen die Auswirkungen der Stall- und Weidehaltung auf die Tiere, die Umwelt, die Verbraucher und die Landwirte untersucht werden. Beteiligt an diesem Verbundprojekt, welches vom niedersächsischen Ministerium für Wissenschaft und Kultur in Auftrag gegeben wurde, sind die Universität Göttingen als tragende Einrichtung sowie die Landwirtschaftskammer Niedersachsen und das Grünlandzentrum Niedersachsen/Bremen als Koordinationspartner. Die zentralen Fragestellungen des Projektes sind:

a) Welche Effekte haben die Systeme (Weidegang/Stallhaltung) auf Tiergesundheit (u.a. Klauen-, Eutergesundheit und Parasitosen), Verhalten und Wohlbefinden der Tiere?

b) Welche Auswirkungen haben die Weidefütterung und die Fütterung mit konserviertem Futter auf die ruminale Fermentation bei Milchkühen?

c) Welche Wechselwirkungen bestehen zur Gesundheit und zum Wohlbefinden?

d) Welche Strategien zur Optimierung der Weidewirtschaft für die Milcherzeugung gibt es?

e) Welches System berücksichtigt die Anforderungen an eine umwelt-, klima- und ressourcenschonende Milcherzeugung am besten?

f) Wie sind die Systeme betriebswirtschaftlich zu bewerten?

g) Gibt es Konsumpräferenzen und Akzeptanzunterschiede für Weide- und Stallmilch?

(www.systemanalyse-milch.de)

Die Untersuchungen der vorliegenden Arbeit betreffen die Fragestellungen a) und c) des Projekts. 


\subsection{Stärken und Schwächen der Weidehaltung}

\subsubsection{Stärken}

Die offensichtlichsten Stärken der Weidehaltung stellen die geringen Futterkosten dar, sofern das Weidemanagement für ausreichend und qualitativ hochwertiges Futter sorgt. Auf das Mähen der Weide und auf die Futteraufbereitung kann verzichtet werden, da die Tiere es selbst von der Weide holen. Nach Albers und KAEMENA (2014) können Milchkühe auf der Weide etwa 25\% ihres täglichen Energiebedarfes zur Erhaltung und Milcherzeugung auf der Weide aufnehmen. Zusätzlich zur Weide werden über die Silage etwa 35\% und über das Kraftfutter nochmal knapp 40\% aufgenommen. Wenn eine ausgedehnte Weidesaison realisiert werden kann, entstehen auch nur geringe Kosten für den Stall, da dort seltener Liegeboxenpflege, nachstreuen der Liegeboxen, Futtervorlage und Reinigung erfolgen muss (REIJS et al., 2013). So zeigte EVERS et al. (2008) durch einen ökonomischen Vergleich von Niederländischen Milchviehbetrieben ein generell höheres Einkommen der Betriebe mit Weidezugang, im Vergleich zu Betrieben mit ganzjähriger Stallhaltung. Ist die warme und trockene Jahreszeit nur auf wenige Monate beschränkt, wie z.B. in Schweden oder Dänemark, ist dieser Vorteil nicht so stark ausgeprägt. Auf der Weide haben die Tiere außerdem die Möglichkeit ihre natürlichen Verhaltensweisen weitestgehend ausleben zu können. Nicht zuletzt ist auch für den Verbraucher das Image der Kühe auf der Weide wünschenswert (REIJS et al., 2013). In vielen Studien wurde bereits gezeigt, dass Weidezugang für Milchkühe Vorteile für die Gesundheit mit sich bringt. So konnten bei Weidehaltung verbesserte Lokomotion, Klauengesundheit (HERNANDEZ-MENDO et al., 2007; Olmos et al., 2009), weniger klinische Mastitiden (WASHBURN et al., 2002) und Mortalität sowie weniger Integumentschäden (BUROW, 2012) im Vergleich zur ganzjährigen Stallhaltung nachgewiesen werden. Auch eine verbesserte Fruchtbarkeit im Zusammenhang mit der leichteren Brunsterkennung kann bei Weidehaltung realisiert werden. Aufreiten und andere Verhaltensweisen sind während der Brunst für die Tiere leichter auf weichem und rutschfestem Boden der Weide auszuführen als im Stall. Insbesondere bei geringen und volatilen Milchpreisen könnte die Weidehaltung als „low-cost“-Strategie Vorteile bieten (REIJS et al., 2013).

\subsubsection{Schwächen}

Schwächen der Weidehaltung von Milchkühen stellt in erster Linie die verminderte Kontrolle über die Futteraufnahme dar. Im Winter kann genau eingeschätzt werden wie viel Futter mit welchen Inhaltsstoffen auf dem Futtertisch vorliegt, im Sommer erfordert die Futteraufnahme auf der Weide eine extra Organisationseinheit im Management des Betriebs. Diese ist schwer einzuschätzen bei wenig Erfahrung mit Weidehaltung und durch die Wetterbedingungen auch schwerer zu kontrollieren. Bezüglich der Arbeitsorganisation erfordert die Weidehaltung für 
viele Landwirte mehr Planung, mehr Know-How über die Weide als Futtergrundlage und dabei auch immer eine erschwerte Tierkontrolle (REIJS et al., 2013). Die fehlende Erfahrung in Praxis und Beratung über die wirtschaftlichen Möglichkeiten, sowie die Fehleinschätzungen der Flächenproduktivität bei Weidegang, stellen ebenfalls aktuelle Schwächen dar (LEISEN, 2014). In vielen Ländern fehlt besonders der neuen Generation von Landwirten Wissen über die Weidehaltung (REIJS et al., 2013). Weidehaltung geht häufig einher mit geringeren Milchleistungen der Tiere, insbesondere aufgrund der schwankenden Futterqualitäten und Futtermengen auf der Weide (REHN et al., 2000). Dadurch besteht auf der Weide ein hohes Risiko der Abmagerung von hochleistenden Tieren sowie eine Verlängerung der Rastzeit (KOHNEN, 2006). Problematisch ist für die Weidehaltung auch die häufige Fehleinschätzung des Zuckergehaltes von Gräsern. Insbesondere bei jungen Weidelgräsern kommt ein geringer Anteil an strukturwirksamer Rohfaser mit hohem Zuckergehalt zusammen, was ein dauerhaftes Absinken des Pansen pH-Wertes zur Folge haben kann. Durch eine solche Veränderung in der mikrobiellen Pansenbesiedelung besteht die Gefahr einer subakuten Pansenazidose (STAUFENBIEL et al., 2007). Hier muss das Fütterungsmanagement sehr bedacht geplant werden, insbesondere bei der Umstellung von einer intensiven Ration mit Weidegang zur Trockensteher-Ration (KOHNEN, 2006).

Nicht optimales Weidemanagement kann auch ein geringeres Betriebseinkommen zur Folge haben. Reicht das Futter auf der Weide nur minimal zur Deckung des Tagesbedarfes der Kühe, muss mehr Geld für zusätzliche Fütterung im Stall ausgegeben werden. Ein Nachteil für Länder wie Irland oder Großbritannien ist auch die saisonale Abkalbung in Verbindung mit der Weidehaltung. Es kann dann dabei keine ganzjährige Lieferung von Milch stattfinden und somit muss der Landwirt immer mit mehreren Wochen rechnen, in denen keine Einkünfte aus dem Milchverkauf erzielt werden. Auch für Händler und Konsumenten ist das ein negatives Argument (REIJS et al., 2013). Insbesondere bei hochleistenden Tieren ist die Weidesaison häufig verbunden mit Schwankungen und Problemen der Körperkondition (HERNANDEZMENDO et al., 2007). Bei ausgedehnter Weidehaltung ist es für manche Betriebe schwierig eine ausgeglichene Fütterung sicherzustellen, die den Tieren über den Tag hinweg genügend Energie-Input liefert, insbesondere bei hochleistenden Tieren (REIJS et al., 2013). Zukünftig werden mit den wachsenden Tierbeständen die nutzbaren und arrondierten Weideflächen knapp, was die Weidehaltung einschränken könnte (LEISEN, 2014). Nicht zuletzt könnten immer extremere Wetterbedingungen durch den Klimawandel die Weidehaltung zusätzlich erschweren (REIJS et al., 2013). 


\subsection{Artgemäße Verhaltensweisen auf der Weide}

Viele Verhaltensweisen der Milchkühe sind in modernen Laufställen häufig nur eingeschränkt möglich. Einschränkende Liegeboxen sowie harter und rutschiger Boden hindern die Tiere häufig an einem natürlichen Bewegungsablauf. Wenig Aktivität und Nichtbeanspruchung bestimmter Muskelgruppen führt jedoch zu verminderter Leistungsfähigkeit des Tieres. (BARTUSSEK, 1999). Auch RelJS et al. (2013) beschreibt, dass das Ausleben von natürlichem Aktivitätsverhalten zu „fitteren“ Kühen, zu besserer Klauengesundheit, besserer Wundheilung und höherer Fruchtbarkeit beiträgt. Auf der Weide können solche natürlichen Verhaltensweisen wie Grasen, Laufen, uneingeschränktes Liegen und Stehen leichter ausgelebt werden.

Rinder laufen auf der Weide durchschnittlich 1 - $13 \mathrm{~km}$ pro Tag und werden dabei vom Leittier in einem bestimmten Rhythmus gesteuert (KROHN et al., 1992). Diese Bewegung ist auf der Weide auch notwendig um eine angemessene Menge Grundfutter auf der Weide zu finden und aufzunehmen. Im Stall ist diese Bewegung durch die Futtervorlage auf dem Futtertisch nicht notwendig (BOCKISCH et al., 1982). Auf der Weide können deutlich dynamischere Vorgänge der Fortbewegung, wie Galoppieren, Springen, Aufreiten usw. ausgeführt werden als im Stall, da für deren Ausübung rutschsicherer und trittfester Boden benötigt wird (BARTUSSEK, 1999). Ein vorsichtiger und langsamer Gang mit gesenktem Kopf, kann in Laufställen, aber nicht auf der Weide beobachtet werden (WLECK und HERRMANN, 1996). WLECK und HERRMANN (1996) weisen außerdem darauf hin, dass die eigene Körperpflege einer Kuh zum Teil nur unter extremen Stellungen des Tieres durchgeführt werden kann, was ebenfalls durch rutschige Böden stark beeinträchtigt wird. Auch beengte räumliche Verhältnisse in den Laufgängen sowie Sackgassen führen zu häufigerem agonistischem Verhalten (BARTUSSEK, 1999).

Beim natürlichen Futteraufnahmeverhalten der Kuh schreitet das Tier während der Futteraufnahme immer weiter voran, dies ist im Stall nicht möglich und auch nicht notwendig. Die Futterauswahl ist bei der Futtervorlage im Stall weitestgehend eingeschränkt und die Kuh kann keinen individuellen Abstand zum Nachbartier wählen, da die Anzahl der Fressplätze im Stall stark begrenzt ist im Vergleich zur Weide. Dieser nicht einhaltbare Abstand zum Nachbartier kann für die Tiere eine soziale Belastung darstellen. Auf der Weide kann ein selbstgewählter Mindestabstand zum nächsten Tier eingehalten werden, was immer von der Rangordnung und den Beziehungen der Tiere untereinander abhängig ist. Die Abstände zwischen den grasenden Tieren auf der Weide betragen meist nicht weniger als 2 bis 3 Meter (BARTUSSEK, 1999). Häufig wird im Stall keine Situation von 1 Liegefläche und 1 Fressplatz pro Kuh ermöglicht. Dann können die Tiere nicht, wie auf der Weide, gemeinsam fressen oder ruhen. Rangniedere Tiere müssen dementsprechend später fressen oder sich hinlegen, wenn ranghöhere Tiere das Fressgitter oder die Liegebox freigegeben haben (RÜTZ, 2010). 
Die Liegeplatzauswahl und ein bequemes Liegen sind in manchen Stallsystemen, im Vergleich zur Weide, stark eingeschränkt (KROHN und MUNKSGAARD, 1993). So behindern beispielsweise falsch eingestellte Nackenriegel das artgerechte Abliegeverhalten und Stangen zum Durchlaufschutz den notwendigen Kopfschwung zum Aufstehen. Die ideale Liegefläche einer Kuh sollte trocken, weich und verformbar sein, was sich insbesondere in Ställen mit Hochboxen nicht umsetzen lässt. Eine Tiefschlafphase (REM-Phase) ist für Kühe nur in völlig entspannter Lage möglich, das heißt das Tier hat die Vorderhand ausgestreckt und der Kopf liegt auf dem Körper oder das Tier befindet sich komplett in flacher Seitenlage. In vielen Ställen wird eine solche Körperhaltung durch die Liegeboxenbegrenzungen nicht ermöglicht (BARTUSSEK, 1999).

Für alle Funktionskreise ist demnach das natürliche Gesamtverhalten im Stall beeinträchtigt. Das Ausmaß dieser Beeinträchtigung hängt jedoch immer vom Stallsystem ab. Ist der Stall tiergerecht gebaut, mit artgemäßen Liegeplätzen, ausreichend Bewegungsfreiheit und einem ausreichenden Tier-Fressplatz- und Tier-Liegeplatzverhältnis, sind die Einschränkungen für die Kühe gering.

\subsection{Literaturverzeichnis}

Albers, D. und F. Kaemena (2014): Projekt „Weideleistung“ - Wie groß ist das Potenzial der Weide? Landwirtschaftskammer Niedersachsen, 1-7.

Algers, B., G. Bertoni, D. Broom, J. Hartung, L. Lidfors, J. Metz, L. Munksgaard, T.N. Pina, P. Oltenacu, J. Rehage und J. Rushen (2009): Scientific report on the effects of farming systems on dairy cow welfare and disease. Report of the Panel on Animal Health and Welfare. Annex to the EFSA Journal (2009) 1143, 1-284.

Bartussek, H. (1999): Die Weidehaltung von Milchkühen aus der Sicht des Tierschutzes. In: Bericht über das 5. Alpenländische Expertenforum zum Thema „Zeitgemäße Weidewirtschaft“ vom 18. - 19. März 1999, BAL Gumpenstein, Irdning, 7-14.

Bockisch, F.-J., A. Zips und A. Boxenberger (1982): Gibt es die „Norm“-Kuh im Liegeboxenlaufstall? Aktuelle Arbeiten zur artgemäßen Tierhaltung 1981, KTBL-Schrift 281, 61-78.

Burow, E. (2012): Welfare of dairy cows in Danish summer grazing herds. Public PhD defence, Aarhus University, Aarhus, Denmark.

Corazzin, M., E. Piasentier, S. Dovier und S. Bovolenta (2010): Effect of summer grazing on welfare of dairy cows reared in mountain tie-stall barns. Italian Journal of Animal Science 9, 304-312.

Dippel, S., M. Dolezal, C. Brenninkmeyer, J. Brinkmann, S. March, U. Knierim und C. Winckler (2009): Risk factors for lameness in freestall-housed dairy cows across two breeds, farming systems, and countries. Journal of Dairy Science 92, 5476-5486. 
Evers, A.G., M.H.A. De Haan, A. Van Den Pol-Van Dasselaar und A.P. Philipsen (2008): Weiden onder moeilijke omstandigheden. Een studie naar inkomensverschillen tussen weiden en opstallen. Animal Sciences Group Wageningen UR, Lelystad, Netherlands.

Harms, J. (2008): Betriebswirtschaftliche Beurteilung der Ergebnisse aus dem Vergleich Stallbzw. Weidehaltung tragender Jungrinder. http://www.landwirtschaft$\mathrm{mv} . \mathrm{de} / \mathrm{cms} 2 / \mathrm{LFA} \_$prod/LFA/content/de/Fachinformationen/Betriebswirtschaft/Archiv_V erfahrensoekonomie/_Dateien/Vergleich_Stall-_Weidehaltung.pdf. Abgerufen am 25.03.2017.

Haskell, M. J., L.J. Rennie, V.A. Bowell, M.J. Bell und A.B. Lawrence (2006): Housing system, milk production, and zero-grazing effects on lameness and leg injury in dairy cows. Journal of Dairy Science 89, 4259-4266.

Hernandez-Mendo, O., M.A.G von Keyserlingk, D.M. Veira und D.M. Weary (2007): Effects of pasture on lameness in dairy cows. Journal of Dairy Science 90, 1209-1214.

Ito, K., M.A. von Keyserlingk, S.J. Leblanc und D.M. Weary (2010): Lying behaviour as an indicator of lameness in dairy cows. Journal of Dairy Science 93, 3553-3560.

Kanswohl, N. und P. Sanftleben (2006): Analyse und Bewertung von Hoch- und Tiefboxen für Milchrinder aus arbeitswirtschaftlicher, ethologischer, hygienischer und ökonomischer Sicht. Forschungsbericht 1/13, Landesforschungsanstalt für Landwirtschaft und Fischerei Mecklenburg-Vorpommern Institut für Tierproduktion, 1-36.

Kohnen, H. (2006): Einfluss der Weide auf den Laktationsverlauf und die Tiergesundheit. In: Tagungsband Internationale Weidetagung, Aulendorf 11.-13. September 2006, 1-21.

Kremer, P. (2006): Vergleich von Klauengesundheit, Milchleistung und Aktivität bei Kühen auf Betonspaltenboden und auf Spaltenboden mit elastischen Auflagen. Veröffentlichte Dissertation, Veterinärmedizinische Fakultät, Ludwig-Maximilians-Universität, München, Deutschland.

Krohn, C., L. Munksgaard und B. Jonasen (1992): Behaviour of dairy cows kept in extensive (loose housing/pasture) or intensive (tie stall) environments. Applied Animal Behaviour Science 34, 37-47.

Krohn, C. und L. Munksgaard (1993): Behaviour of dairy cows kept in extensive or intensive environments. II. Lying and lying-down behaviour. Applied Animal Behaviour Science, 37 (1993), S. 1-16.

Leisen, E. (2014): Weidebasierte Milchviehhaltung in Deutschland. In: Grasland- und weidebasierte Milchproduktion, Mitteilungen der Arbeitsgemeinschaft Grünland und Futterbau Band 16, Internationale Weidetagung, Zollikofen, Schweiz (Hrsg. B. Reidy, B. Gregis und P. Thomet), 98-101.

Leithold, A., E. Ofner-Schröck und A. Preinerstorfer (2011): Evaluierung von ÖPUL Fördermaßnahmen. In: Tagungsband der Konferenz Diversifizierung versus 
Spezialisierung in der Agrar- und Ernährungswirtschaft, 21. Jahrestagung der Österreichischen Gesellschaft für Agrarökonomie. 4.-6.10.2011, Bozen, Italien, 65-66. Mülling, C.H. und P.R. Greenough (2006): Applied Physiopathology of the Foot. http://www.ivis.org/proceedings/wbc/wbc2006/mulling.pdf?LA=1. Abgerufen am 23. Januar 2017.

Olmos G., L. Boyle, A. Hanlo, J. Patton, J.J. Murphy und J.F. Mee (2009): Hoof disorders, locomotion ability and lying times of cubicle-housed compared to pasture based dairy cows. Livestock Science 125, 199-207.

Rehn, H., B. Berglund, U. Emanuelsson, G. Tengroth und J. Philipsson (2000): Milk production in Swedish dairy cows managed for calving intervals of 12 and 15 months. Animal Science 50, 263-271.

Reijs J, C. Daatselaar, J. Helming, J. Jager und A. Beldman (2013): Grazing dairy cows in north-west Europe. LEI Report 2013-001. LEI Wageningen UR, Den Haag, Niederlande.

Rushen, J., E. Pombourcq und A.M. De Passillé (2007): Validation of two measures of lameness in dairy cows. Applied Animal Behaviour Science 106, 173-177.

Rütz, A. (2010): Untersuchung verschiedener Parameter auf ihre Eignung zur Bewertung der Tiergerechtheit von Laufställen für Milchkühe im Rahmen eines On-farm welfare assessment. Veterinärwissenschaftliches Department der Tierärztlichen Fakultät, Ludwig-Maximilians-Universität, München.

Sogstad, A. M., T. Fjeldaas und O. Østerås (2005): Lameness and claw lesions of the Norwegian red dairy cattle housed in free stalls in relation to environment, parity and stage of lactation. Acta Veterinaria Scandinavica 46, 203-217.

Somers, J., K. Frankena, E.N. Noordhuizen-Stassen und J.H.M. Metz (2003): Prevalence of claw disorders in Dutch dairy cows exposed to several floor systems. Journal of Dairy Science 86, 2082-2093.

Staufenbiel, R. (2007): Pansenfermentationsstörung und Pansenazidose - zwei grundlegende fütterungsbedingte Tiergesundheitsstörungen in der Milchkuhhaltung. In: Frühjahrsveranstaltung des Tiergesundheitsdienstes Sachsen-Anhalt: „Aspekte der Fütterung und des Herdenmanagements zur Optimierung von Tiergesundheit und Leistung in der Milchviehhaltung“.

Steinwidder, A. und W. Starz (2006): Sind unsere Kühe für die Weide noch geeignet? In: 13. Freiland-Tagung, 28. September 2006, Kurzfassung der Vorträge an der Veterinärmedizinischen Universität Wien, Österreich.

Telezhenko, E. und C. Bergsten (2005): Influence of floor type on the locomotion of dairy cows. Applied Animal Behaviour Science 93, 183-197. 
Van den Pol - van Dasselaar, A., A. de Vliegher, D. Hennessy, J. Isselstein und J.-L. Peyraud (2015): The Future of Grazing; Proceedings, Third Meeting of the EGF Working Group "Grazing". Wageningen, Livestock Research Report 906, 1-37.

Washburn, S.P., S.L. White, J.T.Jr. Green und G.A. Benson (2002): Reproduction, mastitis, and body condition of seasonally calved Holstein and Jersey cows in confinement or pasture systems. Journal of Dairy Science 85, 105-111.

Weber, A., W. Junge, E. Stamer und G. Thaller (2012): Investigation of locomotion score in dairy cows. In: Tagungsband der 63. jährlichen Konferenz der European federation of animal science. 27. - 30. August 2012, Bratislava, 204.

Weinrich, R., S. Kühl, A. Zühlsdorf und A. Spiller (2014): Consumer attitudes in Germany towards different dairy housing systems and their implications for the marketing of pasture raised milk. International Food and Agribusiness Management Review 17, 205222.

Weiß, D. (2014): Imagewirkung von weidenden Kühen. In: Grasland- und weidebasierte Milchproduktion, Mitteilungen der Arbeitsgemeinschaft Grünland und Futterbau Band 16, Internationale Weidetagung, Zollikofen, Schweiz (Hrsg. B. Reidy, B. Gregis und P. Thomet), 98-101.

Welfare Quality (2012): Welfare Quality® assessment protocol for cattle applied to dairy cows. Welfare Quality® Consortium, Lelystad, Niederlande.

Whay, H.R., A.E. Waterman, A.J.F. Webster und J.K. O'brien (1998): The influence of lesion type on the duration of hyperalgesia associated with hind limb lameness in dairy cattle. Veterinary Journal 156, 23-29.

Wleck, S. und H.-J. Herrmann (1996): Verhaltensbeobachtungen bei Milchkühen zur Ermittlung der Trittsicherheit von Stallfußböden. Arbeiten zur artgemäßen Nutztierhaltung 1995. KTBL-Schrift, 160-168.

Zähner, M., S. Schrade, W. Schaeren und J. Schmidtko (2009): Wiederkäuer: Haltung und Gesundheit: Neue Materialien als Einstreu in Liegeboxen von Milchviehställen. In: Band 2 des Tagungsbandes der 10. Wissenschaftstagung Ökologischer Landbau. 11.-13. Februar 2009. ETH Zürich, 50-53. 
2. Untersuchungen 


\subsection{Does access to pasture affect welfare in dairy cows?}

L. Armbrecht ${ }^{1}$, C. Lambertz ${ }^{2}$, D. Albers ${ }^{3}$ and M. Gauly ${ }^{2}$

${ }^{1}$ Department of Animal Science, University of Göttingen, 37075 Göttingen, Germany

${ }^{2}$ Faculty of Science and Technology, 39100 Bozen, Italy

${ }^{3}$ Chamber of Lower Saxony, Field Testing Station for Grassland Management and Cattle Farming, 26121 Oldenburg, Germany

\section{Abstract}

In terms of animal welfare, dairy cows are perceived positively by consumers when compared to pigs or poultry. This is mainly due to the fact, that the majority of consumers associate dairy farming with pasture, which in turn they relate with benefits for animal health and welfare. However, holistic scientific assessments on the effects of pasturing on animal welfare are rare. Hence, it was the aim to study the animal welfare level in 61 German dairy farms by using the Welfare Quality ${ }^{\circledR}$ protocol for dairy cattle (WQP). Data were collected twice per farm at the end of the pasture season (July to October) and barn season (November to March). Farms were classified based on animals' pasture access during pasture season into: group 1 (G1) > 10 hours pasture access per day; group 2 (G2) 6 - 10 hours; group 3 (G3) < 6 hours and group 4 (G4) without pasture. The average herd size was 129 Holstein-Friesian or RedHolstein cows (range 58 to 527). In addition to WQP-data, performance data were gathered from test-day records. At neither of the two assessments, a farm was classified as the best WQP-category "excellent" or the worst one "not classified". Averaged for both assessments, 43 and $57 \%$ of the farms in G1 and G2 were classified as "enhanced" and "acceptable", respectively. In G3, half of the farms received "enhanced" and the other half "acceptable", while in G4 38\% reached "enhanced" and 63\% "acceptable". For the principle good feeding groups did not differ $(P>0.05)$, whereas for the related criterion absence of hunger all groups were scored worse at the first, compared with the second farm visit $(P<0.05)$. Highest variations of the body condition between summer and winter were noted in groups with access to pasture. Pasturing groups got better results than G4 for the principle good housing at the end of the pasture season $(P<0.05)$ but not in barn confinement $(P>0.05)$. Compared with the two other groups, G1 and G2 reached superior scores at both visits for good health $(P<0.05)$, mainly due to better ratings for the criterion absence of injuries, including indicators such as hairless patches, lesions and swellings and lameness. The principle appropriate behavior did not differ significantly between groups $(P>0.05)$. This study emphasized that pasture access has 
positive effects for certain welfare indicators, even though effects are not considerable during the barn season.

\section{Introduction}

In Germany, only 15 to $30 \%$ of the dairy cows have access to pasture during summer months (WEIB, 2014). Compared to neighboring countries such as Austria (68\%) and Switzerland $(80 \%)$ this is much lower (LEITHOLD et al., 2011). There are several reasons for the decrease of pasture access for dairy cows not only in Germany, but also in many other European countries (VAN DEN POL - VAN DASSELAR et al., 2015). Averaged over Europe, the proportion of dairy cows that are grazing declined from 52\% in 2008 to 35\% in 2012 (REIJS et al., 2013). Growing herd sizes complicate the provision of adequate pasture areas near the milking parlor (LEITHOLD et al., 2011). In addition, for many farmers the substitution of concentrates by grassland is not attractive from an economic point of view, grassland productivity is often underestimated, practical experience lacking and advisory services not focusing on the possibilities of pasture feeding (LEISEN, 2014).

In the current discussion about animal welfare in livestock farming, dairy cows are perceived positively when compared with other livestock species (WEINRICH et al., 2014). This can be mainly explained by the fact, that the majority of consumers associate dairy farming with access to pasture, which in turn is related to benefits for animal health and welfare (WEIB, 2014). In comparison to cows that were housed indoors, animals with access to pasture proved to be superior in terms of hoof health, locomotion ability (HERNANDEZ-MENDO et al., 2007; OLMOS et al., 2009) and other animal-based health parameters such as prevalence of mastitis (WASHBURN et al., 2002), mortality and integument alterations (BUROW, 2012). However, overall on-farm assessments of the effects of pasture access on animal welfare are not available, yet. Comparisons between studies that assessed welfare on pasture are limited due to the fact that either only certain welfare or health indicators were used. For an overall onfarm assessment tool including mainly animal-based measures, beside some indicators related to management and farm resources, the Welfare Quality ${ }^{\circledR}$ assessment protocol (WQP; WELFARE QUALITY ${ }^{\circledR}$, 2012) has been developed (DE VRIES et al., 2013; Gieseke et al., 2014). Hence, it was the aim of the study to assess the welfare level using the WQP in dairy farms without pasture access and those that provide free pasturing for different amount of time per day.

\section{Material and methods}

\section{Farm Selection}

Data were collected in 61 conventional cubicle loose housing dairy farms located in Lower Saxony, Germany. The farms were selected by the chamber of agriculture in Lower Saxony 
according to typical and preferably equal herd sizes in this region that are sustainable and viable in the long term. A mostly equal distribution of herd size between the groups was intended before farms were selected. Cubicles were either straw-bedded ( 27 farms) or equipped with rubber mats (34 farms). Only farms with at least $95 \%$ of the herd consisting of Holstein-Friesian or Red-Holstein cows were included. In 12 of the farms, cows had access to a concreted outdoor area. The average number of cows per farm was 141 (SD = 82.89), ranging from 55 to 585 . The mean energy corrected milk ( $E C M)$ yield was $9,430 \mathrm{~kg}(\mathrm{SD}=892)$. Detailed characteristics of the farms are presented in Table 2.1.2. The 61 farms were classified according to their pasture access into: group $1(\mathrm{G} 1)>10$ hours pasture access per day, group 2 (G2) 6 - 10 hours, group 3 (G3) < 6 hours and group 4 (G4) without access to pasture. Pasture access in $\mathrm{G} 1$ - G3 was provided for at least 120 days per year.

Table 2.1.1 Data collected for the assessment of the overall score of dairy cows using the Welfare Quality® protocol (mod. according to COIGNARD et al., 2013)

\begin{tabular}{|c|c|c|c|}
\hline Indicator & $\begin{array}{l}\text { Type of raw } \\
\text { data }\end{array}$ & $\begin{array}{l}\text { Frequency } \\
\text { calculation }\end{array}$ & $\begin{array}{c}\text { Description of the method for collecting } \\
\text { data }\end{array}$ \\
\hline \multicolumn{4}{|c|}{ Principle Good Feeding } \\
\hline $\begin{array}{l}\text { Body } \\
\text { condition } \\
\text { score (BCS) }\end{array}$ & $\begin{array}{l}\text { Animal-based } \\
\text { indicator }\end{array}$ & $\begin{array}{l}\text { BCS observed on } \\
\text { a sample of cows } \\
\left(\mathrm{N}_{\text {fin }}^{*}\right) \text { on the day of } \\
\text { the visit }\end{array}$ & $\begin{array}{l}\text { BCS of an animal is observed without being } \\
\text { touched and categorized into } \\
0: \text { regular body condition } \\
1 \text { : very lean body condition } \\
2 \text { : very fat body condition }\end{array}$ \\
\hline $\begin{array}{l}\text { Water } \\
\text { provision }\end{array}$ & $\begin{array}{l}\text { Resource- } \\
\text { based } \\
\text { indicator }\end{array}$ & $\begin{array}{l}\text { Length, } \\
\text { cleanliness and } \\
\text { functionality of } \\
\text { water troughs and } \\
\text { bowls on the day } \\
\text { of the visit }\end{array}$ & $\begin{array}{l}\text { Troughs: length indicator in } \mathrm{cm} \text { and test of } \\
\text { sufficient water flow (sufficient }=20 \mathrm{l} / \mathrm{min} \text { ) } \\
\text { Bowls: number of bowls and test of sufficient } \\
\text { water flow (sufficient }=10 \mathrm{l} / \mathrm{min} \text { ) } \\
\text { Check of cleanliness in all water troughs or } \\
\text { bowls }\end{array}$ \\
\hline \multicolumn{4}{|c|}{ Principle Good Housing } \\
\hline $\begin{array}{l}\text { Time } \\
\text { needed to } \\
\text { lie down }\end{array}$ & $\begin{array}{l}\text { Animal-based } \\
\text { indicator }\end{array}$ & $\begin{array}{l}\text { Mean time to lie } \\
\text { down observed on } \\
\text { a sample of at } \\
\text { least } 6 \text { cows on } \\
\text { the day of the visit }\end{array}$ & $\begin{array}{l}\text { Recording of time needed to lay down in } \\
\text { seconds with a chronograph. From the } \\
\text { moment, the carpal joint was bent and } \\
\text { lowered to touch the ground, the time } \\
\text { measure started. With the movement of } \\
\text { pulling the front legs out from underneath the } \\
\text { body, when the hind quarter had already } \\
\text { fallen down, time measure stopped }\end{array}$ \\
\hline Cleanliness & $\begin{array}{l}\text { Animal-based } \\
\text { indicator }\end{array}$ & $\begin{array}{l}\text { Cleanliness } \\
\text { observed on a } \\
\text { sample of cows } \\
\left(\mathrm{N}_{\text {tin }}^{*}\right) \text { on the day of } \\
\text { the visit }\end{array}$ & $\begin{array}{l}\text { Assessment on lower hind legs, hind quarters } \\
\text { and udder, Animal is observed without being } \\
\text { touched. Assessed using this scale: } \\
0: \text { no dirt or minor splashing } \\
\text { 2: separate or continuous plaques of dirt }\end{array}$ \\
\hline Collisions & $\begin{array}{l}\text { Animal-based } \\
\text { indicator }\end{array}$ & $\begin{array}{l}\text { Observed on a } \\
\text { sample of at least } \\
6 \text { cows on the day } \\
\text { of the visit }\end{array}$ & $\begin{array}{l}\text { Definition of a collision: during the lying down, } \\
\text { the cow collides with the housing equipment. } \\
0: \text { no collision } \\
\text { 2: collision }\end{array}$ \\
\hline $\begin{array}{l}\text { Lying } \\
\text { outside the } \\
\text { lying area }\end{array}$ & $\begin{array}{l}\text { Animal-based } \\
\text { indicator }\end{array}$ & $\begin{array}{l}\text { Observed in repre- } \\
\text { sentative } \\
\text { segments of the }\end{array}$ & $\begin{array}{l}\text { Percentage of animals lying partly or } \\
\text { completely outside the designated lying area, } \\
\text { out of all lying animals }\end{array}$ \\
\hline
\end{tabular}


barn/ pasture on

the day of the visit

\begin{tabular}{|c|c|c|c|}
\hline $\begin{array}{l}\text { Presence of } \\
\text { tethering }\end{array}$ & --- & --- & $\begin{array}{l}\text { Only farms with cubicle housing systems were } \\
\text { chosen for this study }\end{array}$ \\
\hline
\end{tabular}

\section{Principle Good Health}

\begin{tabular}{|c|c|c|c|}
\hline Lameness & $\begin{array}{l}\text { Animal-based } \\
\text { indicator }\end{array}$ & $\begin{array}{l}\text { Prevalence of } \\
\text { lameness } \\
\text { observed on a } \\
\text { sample of cows } \\
\left(\mathrm{N}_{\text {fin }}{ }^{*}\right) \text { on the day of } \\
\text { the visit }\end{array}$ & $\begin{array}{l}\text { Cows are observed when walking on a } \\
\text { surface on which they normally walk. The } \\
\text { cows gait score is assessed using this scale: } \\
0: \text { Not lame: timing of steps and weight- } \\
\text { bearing equal on all four feet } \\
1 \text { : Moderately lame: imperfect temporal } \\
\text { rhythm in stride creating a limp } \\
2 \text { : Severely lame: Strong reluctance to bear } \\
\text { weight on one limb, or more than one limb } \\
\text { affected }\end{array}$ \\
\hline $\begin{array}{l}\text { Integument } \\
\text { alterations }\end{array}$ & $\begin{array}{l}\text { Animal-based } \\
\text { indicator }\end{array}$ & $\begin{array}{l}\text { Prevalence of } \\
\text { integument altera- } \\
\text { tions observed on } \\
\text { a sample of cows } \\
\left(\mathrm{N}_{\text {fin }}{ }^{*}\right) \text { on the day of } \\
\text { the visit }\end{array}$ & $\begin{array}{l}\text { Observation of five body regions of cows } \\
\text { (neck/ shoulder/ back, hindquarter, tarsus, } \\
\text { flank/ side/ udder, carpus) on one side of the } \\
\text { animal. On each region, the number of } \\
\text { hairless patches and lesions/ swellings of a } \\
\text { minimum diameter of } 2 \mathrm{~cm} \text { are recorded }\end{array}$ \\
\hline $\begin{array}{l}\text { Nasal } \\
\text { discharge }\end{array}$ & $\begin{array}{l}\text { Animal-based } \\
\text { indicator }\end{array}$ & $\begin{array}{l}\text { Prevalence of } \\
\text { nasal discharge } \\
\text { observed on a } \\
\text { sample of cows } \\
\left(\mathrm{N}_{\mathrm{fin}}{ }^{*}\right) \text { on the day of } \\
\text { the visit }\end{array}$ & $\begin{array}{l}\text { Animal is observed without being touched. } \\
\text { Assessed using this scale: } \\
0: \text { No evidence } \\
1 \text { : Evidence of clearly visible flow/ discharge } \\
\text { from the nostrils; transparent to yellow/ green } \\
\text { and often of thick consistency }\end{array}$ \\
\hline $\begin{array}{l}\text { Ocular } \\
\text { discharge }\end{array}$ & $\begin{array}{l}\text { Animal-based } \\
\text { indicator }\end{array}$ & $\begin{array}{l}\text { Prevalence of } \\
\text { ocular discharge } \\
\text { observed on a } \\
\text { sample of cows } \\
\left(\mathrm{N}_{\text {fin }}{ }^{*}\right) \text { on the day of } \\
\text { the visit }\end{array}$ & $\begin{array}{l}\text { Animal is observed without being touched. } \\
\text { Assessed using this scale: } \\
0: \text { No evidence } \\
\text { 1: Evidence of clearly visible flow/ discharge } \\
\text { (wet or dry) from the eye, at least } 3 \mathrm{~cm} \text { long }\end{array}$ \\
\hline Diarrhea & $\begin{array}{l}\text { Animal-based } \\
\text { indicator }\end{array}$ & $\begin{array}{l}\text { Prevalence of } \\
\text { diarrhea observed } \\
\text { on a sample of } \\
\text { cows }\left(\mathrm{N}_{\text {fin }}^{*}\right) \text { on the } \\
\text { day of the visit }\end{array}$ & $\begin{array}{l}\text { Animal is observed without being touched. } \\
\text { Assessed using this scale: } \\
0: \text { No evidence } \\
1 \text { : Evidence of loose watery manure on both } \\
\text { sides of the tail. Area affected at least the size } \\
\text { of a hand }\end{array}$ \\
\hline Coughing & $\begin{array}{l}\text { Animal-based } \\
\text { indicator }\end{array}$ & $\begin{array}{l}\text { Mean number of } \\
\text { coughs expressed } \\
\text { per cow per } 15 \text { min }\end{array}$ & $\begin{array}{l}\text { Recording using continuous behavior } \\
\text { sampling of sudden and noisy expulsion of air } \\
\text { from the lungs of cows during a total period of } \\
120 \text { minutes }\end{array}$ \\
\hline $\begin{array}{l}\text { Vulvar } \\
\text { discharge }\end{array}$ & $\begin{array}{l}\text { Animal-based } \\
\text { indicator }\end{array}$ & $\begin{array}{l}\text { Prevalence of } \\
\text { vulvar discharge } \\
\text { observed on a } \\
\text { sample of cows } \\
\left(\mathrm{N}_{\text {fin }}{ }^{*}\right) \text { on the day of } \\
\text { the visit }\end{array}$ & $\begin{array}{l}\text { Animal is observed without being touched. } \\
\text { Assessed using this scale: } \\
0: \text { No evidence } \\
1 \text { : Evidence of purulent effluent from the vulva } \\
\text { or on the bottom side of the tail }\end{array}$ \\
\hline Mortality & Farm records & $\begin{array}{l}\text { Annual cumulative } \\
\text { incidence of } \\
\text { mortality }\end{array}$ & $\begin{array}{l}\text { Defined as the percentage of dairy cows } \\
\text { which died or were euthanized due to disease } \\
\text { or accidents or were emergency slaughtered } \\
\text { during the last } 12 \text { months }\end{array}$ \\
\hline $\begin{array}{l}\text { Milk } \\
\text { somatic cell } \\
\text { count }\end{array}$ & Farm records & $\begin{array}{l}\text { Prevalence of } \\
\text { cows with } \\
\text { subclinical mastitis }\end{array}$ & $\begin{array}{l}\text { Cow milk somatic cell counts are obtained } \\
\text { from individual milk records and assessed } \\
\text { using this scale: }\end{array}$ \\
\hline
\end{tabular}


within the last 3 months
0 : Somatic cell count below 400,000 cell $/ \mathrm{ml}$ for the last 3 months

1: Somatic cell count of $400,000 \mathrm{cell} / \mathrm{ml}$ or above at least once within the last 3 months

\begin{tabular}{|c|c|c|c|}
\hline $\begin{array}{l}\text { Downer } \\
\text { cows }\end{array}$ & Farm records & $\begin{array}{l}\text { Annual cumulative } \\
\text { incidence of } \\
\text { downer cows }\end{array}$ & $\begin{array}{l}\text { Defined as the percentage of cases of downer } \\
\text { cows in the herd during the last } 12 \text { months }\end{array}$ \\
\hline Dystocia & Farm records & $\begin{array}{l}\text { Annual incidence } \\
\text { of dystocia }\end{array}$ & $\begin{array}{l}\text { Defined as the percentage of calvings where } \\
\text { major assistance was required in the herd } \\
\text { during the last } 12 \text { months }\end{array}$ \\
\hline $\begin{array}{l}\text { Hampered } \\
\text { respiration }\end{array}$ & $\begin{array}{l}\text { Animal-based } \\
\text { indicator }\end{array}$ & $\begin{array}{l}\text { Prevalence of } \\
\text { hampered respi- } \\
\text { ration observed on } \\
\text { a sample of cows } \\
\left(\mathrm{N}_{\text {fin }}^{*}\right) \text { on the day of } \\
\text { the visit }\end{array}$ & $\begin{array}{l}\text { Animal is observed without being touched. } \\
\text { Assessed using this scale: } \\
0: \text { No evidence } \\
\text { 1: Evidence of deep and labored respiration. } \\
\text { Expiration mostly accompanied by } \\
\text { pronounced sound }\end{array}$ \\
\hline $\begin{array}{l}\text { Disbudding/ } \\
\text { dehorning }\end{array}$ & Questionnaire & --- & $\begin{array}{l}\text { The farmer is asked about his or her } \\
\text { management practices for disbudding/ } \\
\text { dehorning (procedures, use of } \\
\text { anesthetics/analgesics) }\end{array}$ \\
\hline $\begin{array}{l}\text { Tail } \\
\text { docking }\end{array}$ & --- & --- & $\begin{array}{l}\text { Not practiced in Germany except an } \\
\text { emergency case }\end{array}$ \\
\hline
\end{tabular}

Principle Appropriate Behavior

Observed in representative segments of the barn/ pasture on the day of the visit

Outdoor

loafing area Questionnaire ---
or pasture

Animal-based indicator

Recording of agonistic behavior using continuous behavior sampling during a total period of 120 minutes: Number of head butts, displacements, chasing (-up) and fightings

Access to outdoor loafing area and/ or pasture:

0 : yes

2: no

Starting at $2 \mathrm{~m}$ in front of the cow at the feed bunk, the observer approached the animal with an extended hand. If the cow showed withdrawal, the avoidance distance was estimated between the hand and the muzzle of the cow at the moment of first sign of retraction, noted in $10 \mathrm{~cm}$ intervals

Equal distributed segments, observed for 20
Qualitative behavior (QBA) assessment indicator
Animal-based indicator
Observed on a sample of cows $\left(\mathrm{N}_{\text {fin }}{ }^{*}\right)$ on the day of the visit minutes overall. The herd was valued for a tendency to be active, relaxed, fearful, agitated, calm, content, indifferent, frustrated, friendly, bored, playful, positively occupied, lively, inquisitive, irritable, uneasy, sociable, apathetic, happy or distressed

${ }^{*} N_{\text {fin }}=\frac{N_{\text {inf }}}{1+\frac{\left(N_{\text {inf }}-1\right)}{N}}$ with $N_{\text {inf }}=96.04$ and $N=$ herd size.

\section{Data Collection}

Each farm was assessed from July 2014 to April 2015, using the 32 animal-, managementand resource-based indicators as described in the WQP, two times. The initial assessment was carried out from July to October 2014, when the cows in G1, G2 and G3 had access to 
pasture. About six months later, the second assessment took place during the barn confinement season. All assessments were conducted by the first author, who was educated as an animal scientist with experience in dairy farming and animal behavior assessment. Prior to the study, the author was trained on the correct application of the WQP by an assessor, who received official training according to Welfare Quality ${ }^{\circledR}$. Before assessments for this study started, inter-observer reliability for any of the WQP measures was reached. Detailed definitions of all measures are given in Table 2.1.1.

Every assessment started maximum one hour after milking in the morning. The order of measures was carried out as stated in the WQP. After the cows left the milking parlor feed was provided at the feed bunk. The first assessment was the test of avoidance distance, while the sample size depended on the herd size. Cows were selected for sampling when animals were locked in the feeding rack and by choosing every $\mathrm{n}^{\text {th }}$ animal in the row. Details are provided in Table 2.1.1. Thereafter the QBA was carried out followed by the observations of social behavior. For groups with pasture access behavioral observations occurred on the pasture in the summer months, if the weather permitted pasture access. So, 31 of 45 farms were assessed on the pasture on the first farm visit in summer. After that the clinical scoring was conducted. Clinical parameters were assessed when the animals were in the barn or a yard prior to the afternoon milking. Besides, the farmer was interviewed to collect data on farm resources and management routines. In addition to the WQP, data on cubicle design, animalto-feeding-place ratio and animal-to-cubicle ratio were recorded.

\section{Assessment of resource- and management-based indicators}

Among the resource-based indicators, length of water trough (in $\mathrm{cm}$ ), quantity, functionality (water flow) and cleanliness were recorded. The management-based indicators included recording of the method of dehorning and the use of analgesics or anesthetics. Characteristics on milk production (i.e. yield, fat and protein percentage) were gathered from official records.

\section{Assessment of animal-based indicators}

Depending on the total herd size of the respective farm, the animal-based indicators were assessed for samples between 34 and 82 cows, calculated according to the WQP. A total number of 6,354 individual animals were assessed in both farm visits, with 3,128 cows in the first and 3,226 cows in the second farm visit.

The animal-based measures consisted in clinical indicators, animal behavior, assessed with the Qualitative Behavioral Assessment (QBA), an avoiding-distance-test and observations of the social and lying-down behavior. The procedure of clinical scoring of the animals is provided by the WQP. Only one side of the animal was examined. Clinical scoring included skin alterations, cleanliness of legs, udders, upper legs and flanks and indications of diseases like 
nasal, ocular or vulva discharges, increased respiratory rate and diarrhea. For integument alterations, the number of hairless patches, lesions and swellings was noted. These indicators were categorized by a binary variable (absent or present). A three-point scale was used for body condition score $(B C S)(0=$ regular, $1=$ very lean, $2=$ very fat $)$ and lameness $(0=$ not lame, 1 = lame, 2 = severely lame). For the QBA, the herd was divided into evenly distributed segments (up to eight observation points) and was observed for a total of 20 minutes. The following adjectives were included in the QBA and assessed by a visual analogue scale: active, relaxed, fearful, agitated, calm, content, indifferent, frustrated, friendly, bored, playful, positively occupied, lively, inquisitive, irritable, uneasy, sociable, apathetic, happy and distressed. To evaluate the avoidance distance, the observer approached the animal to be tested on the feed bunk from an initial distance of two meters. The observer started with an extended hand and approached the animal with a speed of one step per second. If the cow showed any sign of withdrawal, the avoidance distance was estimated between the hand and the muzzle of the cow, at the moment of the first sign of retraction. If the muzzle could not be touched, an avoidance distance of 10 to $200 \mathrm{~cm}$ was estimated in $10 \mathrm{~cm}$ intervals. During a herd observation of two hours, the number of coughs, lying-down and social behavior were recorded. For the lying-down behavior, the number of animals was noted, which lay down and how many of them were lying in their cubicles, but with their hind quarters on the edge of the cubicle. It was also noted how many cows are lying completely outside of the designated lying area. For animals that lay down during the observation period, the time needed to lay down and collisions with the cubicle were recorded. A minimum sample size of six animals was assessed for lying-down behavior. The social behavior included the parameters fighting, chasing, displacing or head-butting. For the assessment of this, the herd was divided into groups of maximum 25 animals. Assessment duration for each group was equal and summed up to two hours. If herd sizes were too large, representative segments were selected.

\section{Statistical analysis}

The data for the Welfare Quality ${ }^{\circledR}$ protocol was calculated for each farm using an excel sheet provided by INRA. The single indicators were aggregated to criteria, principles and overall score. The following linear mixed effects model was used to analyze overall score, principles, criteria and indicators:

$$
Y_{i j k}=\mu+a_{i}+b_{j}+c_{i j}+d_{k}+e_{m}+\varepsilon_{i j k}
$$

with $\mathrm{Y}_{\mathrm{ijk}}=$ degree of overall score/ principles/ criteria/ indicators, $\mu=$ overall average of sample, $a_{i}=$ fixed effect of group $i(G 1, G 2, G 3, G 4), b_{j}=$ fixed effect of farm visit $j(1,2), c_{i j}=$ interaction between group $i$ and farm visit $j, d_{k}=$ random effect of the farm $k, e_{m}=$ fixed effect of cubicle flooring $\mathrm{m}$ (deep-bedded, rubber mats) and $\varepsilon_{\mathrm{ijk}}=$ residual error. Data on milk production were analyzed with the same model including only the fixed effect of group. All statistical analyses 
were computed with SAS, version 9.3 (Statistical Analysis Systems, Cary, NC, USA) using the GLIMMIX procedure. Farm was defined as the statistical unit. Results were considered statistically significant at a probability of $\alpha<0.05$. Differences between groups were assessed by applying the Tukey-Kramer test for unbalanced data. Data were log-, sqrt- or arcsintransformed, prior to analysis, if normal distribution was not given. To avoid bias of the estimators, all values given in the results are presented with the non-transformed data. For parameters that did not approximate normal distribution even after transformation, either Poisson or binomial distribution within the GLIMMIX procedure were applied to calculate $p$ values. The parameter access to pasture, which was the only input variable to calculate the criterion expression of other behaviors, was not considered for the analysis, because the groups were classified based on this indicator. Following, the indicator access to pasture was set to zero for all groups.

\section{Results}

\section{Farm characteristics}

As presented in Table 2.1.2, herd sizes in group 4 averaged 181 cows while those in the pasture groups averaged 104 to 126 cows, whereas variation within groups was high. Groups with more than six hours pasture access $(G 1, G 2)$ showed lower energy corrected milk yields (ECM) than the groups $G 3$ and $G 4(P<0.01)$. Protein content was not different between groups and averaged between 3.35 to $3.40 \%$, comparable to the average fat content, which varied between 3.98 and $4.12 \%$ among groups. Cubicles of farms with pasture access were predominantly equipped with rubber mats, whereas farms without pasture provided mainly deep-bedded cubicles.

\section{Overall assessment}

Following the score aggregation process, as described in the WQP, each farm was classified into one of four overall assessment categories. None of the farms received the classification "excellent" or "not classified". The distribution for "enhanced" and "acceptable" farms in dependence of the pasture group is shown in Table 2.1.3. In the summer months 10 farms of G1 were classified in the category "enhanced" and only three farms in winter. G2, G3 and G4 in contrast, showed more farms in the category "enhanced" in winter compared to summer months.

LS Means for the overall WQP scores amounted in summer and winter, respectively: G1: $49 \pm 6.5$ and $43 \pm 5.8, \mathrm{G} 2: 45 \pm 5.6$ and $47 \pm 4.0, \mathrm{G} 3: 45 \pm 10.2$ and $45 \pm 6.0, \mathrm{G} 4: 41 \pm 7.0$ and $45 \pm 5$.3. There was a significant effect of interaction between the groups and the farm visit $(P<0.05)$. G1 indicated higher overall scores in the summer, compared to the winter months, G2 and G4 showed an inverse relation. 
Table 2.1.2 Characteristics (herd size, energy corrected milk yield (ECM), protein and fat percentage, cubicle design) of 61 dairy farms with $>10$ hours (G1), 6 to 10 hours (G2), $<6$ hours of pasture access/day (G3) or without pasture access (G4) (LS Means \pm SE)

\begin{tabular}{|c|c|c|c|c|}
\hline $\begin{array}{c}\text { Farm } \\
\text { characteristics }\end{array}$ & $\begin{array}{c}\text { Group } 1 \\
\mathrm{~N}=15\end{array}$ & $\begin{array}{c}\text { Group } 2 \\
\mathrm{~N}=15\end{array}$ & $\begin{array}{c}\text { Group } 3 \\
\mathrm{~N}=15\end{array}$ & $\begin{array}{c}\text { Group } 4 \\
\mathrm{~N}=16\end{array}$ \\
\hline Herd size ${ }^{\text {n.s. }}$ & $104( \pm 14.47)$ & $111( \pm 14.47)$ & $126( \pm 14.47)$ & $181( \pm 14.01)$ \\
\hline Range & $55-227$ & $63-243$ & $65-300$ & $63-585$ \\
\hline $\mathrm{ECM}(\mathrm{kg})$ & $8,957^{a}( \pm 169)$ & $9,002^{a}( \pm 161)$ & $9,824^{b}( \pm 164)$ & $9,896^{b}( \pm 154)$ \\
\hline Range & $7,220-10,758$ & $6,950-10,608$ & $7,921-10,911$ & $7,778-11,460$ \\
\hline Protein (\%) ${ }^{\text {n.s. }}$ & $3.40( \pm 0.01)$ & $3.35( \pm 0.01)$ & $3.40( \pm 0.01)$ & $3.38( \pm 0.01)$ \\
\hline Range & $3.30-3.60$ & $3.21-3.49$ & $3.26-3.54$ & $3.17-3.50$ \\
\hline Fat $(\%)^{\text {n.s. }}$ & $4.05( \pm 0.04)$ & $4.10( \pm 0.04)$ & $4.12( \pm 0.04)$ & $3.98( \pm 0.04)$ \\
\hline Range & $3.80-4.30$ & $3.86-4.44$ & $3.93-4.58$ & $3.66-4.31$ \\
\hline $\begin{array}{l}\text { Deep-bedded } \\
\text { cubicles (no. of farms) }\end{array}$ & $4^{a}$ & $6^{a}$ & $6^{a}$ & $11^{b}$ \\
\hline $\begin{array}{l}\text { Cubicles with rubber } \\
\text { mats (no. of farms) }\end{array}$ & $11^{\mathrm{a}}$ & $9^{a}$ & $9^{a}$ & $5^{b}$ \\
\hline
\end{tabular}

a,b Values within a row with different superscripts differ significantly $\mathrm{P}<0.05$ (Tukey-test/ Chi square).

n.s. no significant differences between the groups (Tukey-test).

Table 2.1.3 Overall Welfare Quality ${ }^{\circledR}$ classification at the end of the pasture (visit 1, summer 2014) and barn season (visit 2, winter 2014/15) for dairy farms with $>10$ hours (Group 1), 6 to 10 hours (Group 2), < 6 hours of pasture access/day (Group 3) or without pasture access (Group 4)

\begin{tabular}{|c|c|c|c|c|c|}
\hline \multirow{2}{*}{ Group* } & \multirow{2}{*}{ Farm Visit } & \multicolumn{4}{|c|}{ Welfare Quality ${ }^{\circledR}$ category } \\
\hline & & excellent & enhanced & acceptable & not classified \\
\hline \multirow{2}{*}{$1(\mathrm{~N}=15)$} & Summer & 0 & 10 & 5 & 0 \\
\hline & Winter & 0 & 3 & 12 & 0 \\
\hline \multirow{2}{*}{$2(\mathrm{~N}=15)$} & Summer & 0 & 5 & 10 & 0 \\
\hline & Winter & 0 & 8 & 7 & 0 \\
\hline \multirow{2}{*}{$3(\mathrm{~N}=15)$} & Summer & 0 & 6 & 9 & 0 \\
\hline & Winter & 0 & 9 & 6 & 0 \\
\hline \multirow{2}{*}{$4(N=16)$} & Summer & 0 & 4 & 12 & 0 \\
\hline & Winter & 0 & 8 & 8 & 0 \\
\hline
\end{tabular}

* no differences between the groups $(P>0.05$, Chi Square). 


\section{Welfare principles and criteria}

Results of the principles and criteria are given in Table 2.1.4. Groups did not differ for the principle good feeding $(\mathrm{P}>0.05)$, whereas for the related criterion absence of hunger all groups received lower scores $(43.51 \pm 3.1)$ at the first, compared with the second farm visit in winter $(50.25 \pm 3.1, P<0.05)$. A large difference was noted in all groups with pasturing between summer and winter. The criterion absence of thirst differed neither between groups nor farm visits $(P>0.05)$. An effect of group, farm visit and its interaction was found for the principle good housing $(P<0.01)$. Differing from $G 4$, all other groups received higher scores in summer compared with winter, in particular $\mathrm{G} 1$ and $\mathrm{G} 2$ with most intensive pasturing. At the end of the barn season the level was similar among the four groups concerning this principle. The related criterion comfort around resting showed comparable relationships. The other two related criteria thermal comfort and ease of movement were not shown in Table 2.1.4. As only loose-housing farms were included in the study, all farms reached the maximum score for the criterion ease of movement. For thermal comfort, there is still no measure identified in the WQP. Groups with more hours on pasture (G1 and G2) showed better results than G4 for the principle good health $(P<0.01)$. Within this principle, the scores for the related criterion absence of injuries were found to rise with increasing pasturing intensity. Absence of diseases showed differences between the groups $(P<0.05)$ but not for the farm visit $(P>0.05), G 2$ indicated better results than $\mathrm{G} 1$ and $\mathrm{G} 4$. As another determining criterion absence of pain was, in tendency, rated better in $\mathrm{G} 1$ and $\mathrm{G} 2$ than in $\mathrm{G} 3$ and $\mathrm{G} 4(\mathrm{P}<0.1)$. The principle appropriate behavior, as well as its related criteria, did not show differences between the groups or farm visits $(P>0.05)$.

\section{Welfare indicators}

As shown in Table 2.1.5, all groups had more very lean animals during summer, compared with winter months $(P<0.05)$. Dirty water troughs were only observed during summer, though in $10 \%$ of the G1-farms and in nearly $7 \%$ of the G3-farms, troughs were classified as dirty. In G2 and G4 approximately 3\% of the farms were assessed with dirty throughs. Animals of all groups needed more time to lay down in winter than in summer months $(P<0.01)$. Except for G1, animals were less clean in summer than in winter $(P<0.01)$. When further differentiating into body parts, dirty legs ( $84.43 \pm 2.37$ vs. $31.35 \pm 2.37, P<0.01)$ occurred more frequently in summer than in winter months, dirty udders showed no significant differences $(10.53 \pm 1.19$ vs. $7.99 \pm 1.19, P>0.05)$. G3 and G4 showed less dirty legs in the winter months than $G 1$ and $\mathrm{G} 2(\mathrm{P}<0.05$ - group * farm visit effect). Averaged over both visits, increased percentages of dirty udders were found in $G 2$ and G4, compared to $G 1$ and $G 3$ (G1: 7.00, G2: 11.01, G3: 8.53, G4: 11.33) ( $P<0.05$ - Tukey test). However, the indicator dirty flanks showed a lower prevalence in summer compared to winter months $(34.24 \pm 2.36$ vs. $47.77 \pm 2.36, P<0.01$ farm visit effect). 
Table 2.1.4 Results of the Welfare Quality ${ }^{\circledR}$ assessments at the level of principles and criteria at the end of the pasture (visit 1, summer 2014) and barn season (visit 2, winter 14/15) for dairy farms with > 10 hours (G1), $6-10$ hours (G2), < 6 hours of pasture access/day (G3) or without pasture access (G4) (LS Means \pm Standard Error)

\begin{tabular}{|c|c|c|c|c|c|c|c|c|c|c|c|}
\hline \multirow{3}{*}{ Principles/ Criteria } & \multirow{2}{*}{\multicolumn{2}{|c|}{$\begin{array}{l}\mathbf{G 1}(\mathbf{N}=15) \\
\text { Farm visit }\end{array}$}} & \multirow{2}{*}{\multicolumn{2}{|c|}{$\begin{array}{l}\mathbf{G} 2(\mathrm{~N}=15) \\
\text { Farm visit }\end{array}$}} & \multirow{2}{*}{\multicolumn{2}{|c|}{$\begin{array}{l}\text { G3 }(\mathbf{N}=15) \\
\text { Farm visit }\end{array}$}} & \multirow{2}{*}{\multicolumn{2}{|c|}{$\begin{array}{l}\mathbf{G} 4 \mathbf{( N = 1 6 )} \\
\text { Farm visit }\end{array}$}} & \multicolumn{3}{|c|}{$P$ - value } \\
\hline & & & & & & & & & \multirow{2}{*}{ Group } & \multirow{2}{*}{$\begin{array}{l}\text { Farm } \\
\text { visit }\end{array}$} & \multirow{2}{*}{$\begin{array}{l}\text { Group } \\
\text { x visit }\end{array}$} \\
\hline & 1 & 2 & 1 & 2 & 1 & 2 & 1 & 2 & & & \\
\hline Good Feeding & $38.2 \pm 6.1$ & $39.3 \pm 6.1$ & $35.7 \pm 5.9$ & $44.5 \pm 5.9$ & $42.7 \pm 6.1$ & $47.4 \pm 6.1$ & $49.4 \pm 5.9$ & $51.6 \pm 5.9$ & 0.12 & 0.26 & 0.88 \\
\hline Absence of Hunger & $43.8 \pm 5.0$ & $50.5 \pm 5.0$ & $34.7 \pm 4.9$ & $48.6 \pm 4.9$ & $46.9 \pm 5.0$ & $52.0 \pm 5.0$ & $48.7 \pm 4.9$ & $49.9 \pm 4.9$ & 0.21 & $<0.05$ & 0.58 \\
\hline Absence of Thirst & $56.6 \pm 8.8$ & $54.0 \pm 8.8$ & $64.8 \pm 8.7$ & $68.8 \pm 8.7$ & $66.9 \pm 8.7$ & $71.5 \pm 8.7$ & $73.6 \pm 8.5$ & $78.6 \pm 8.5$ & 0.12 & 0.69 & 0.97 \\
\hline Good Housing & $76.5 \pm 2.6$ & $53.6 \pm 2.6$ & $65.7 \pm 2.6$ & $58.9 \pm 2.6$ & $61.6 \pm 2.6$ & $58.4 \pm 2.6$ & $44.9 \pm 2.5$ & $54.3 \pm 2.5$ & $<0.01$ & $<0.01$ & $<0.01$ \\
\hline Comfort a. resting & $62.8 \pm 4.2$ & $26.4 \pm 4.2$ & $45.6 \pm 4.1$ & $34.8 \pm 4.1$ & $39.1 \pm 4.1$ & $34.0 \pm 4.1$ & $12.5 \pm 4.0$ & $27.4 \pm 4.0$ & $<0.01$ & $<0.05$ & $<0.01$ \\
\hline Good Health & $48.1 \pm 2.6$ & $44.4 \pm 2.6$ & $44.5 \pm 2.5$ & $51.8 \pm 2.5$ & $42.0 \pm 2.6$ & $42.4 \pm 2.6$ & $35.6 \pm 2.5$ & $41.0 \pm 2.5$ & $<0.01$ & 0.17 & 0.11 \\
\hline Absence of Injuries & $59.5 \pm 3.2$ & $49.7 \pm 3.2$ & $44.0 \pm 3.1$ & $48.8 \pm 3.1$ & $41.4 \pm 3.2$ & $45.2 \pm 3.2$ & $33.0 \pm 3.1$ & $39.1 \pm 3.1$ & $<0.01$ & 0.26 & $<0.05$ \\
\hline Absence of Diseases & $34.7 \pm 2.3$ & $31.7 \pm 2.3$ & $36.0 \pm 2.2$ & $42.0 \pm 2.2$ & $34.1 \pm 2.2$ & $36.1 \pm 2.2$ & $33.5 \pm 2.2$ & $33.4 \pm 2.2$ & $<0.05$ & 0.43 & 0.24 \\
\hline Absence of Pain & $66.0 \pm 4.6$ & $70.5 \pm 4.6$ & $68.8 \pm 4.5$ & $75.1 \pm 4.5$ & $60.2 \pm 4.5$ & $63.7 \pm 4.5$ & $60.0 \pm 4.4$ & $61.3 \pm 4.4$ & 0.06 & 0.24 & 0.97 \\
\hline Appropr. Behavior & $37.5 \pm 1.4$ & $37.6 \pm 1.4$ & $35.6 \pm 1.4$ & $35.8 \pm 1.4$ & $35.4 \pm 1.4$ & $36.4 \pm 1.4$ & $37.0 \pm 1.4$ & $37.4 \pm 1.4$ & 0.47 & 0.67 & 0.99 \\
\hline Social Behavior & $94.8 \pm 1.5$ & $96.1 \pm 1.5$ & $97.6 \pm 1.4$ & $92.5 \pm 1.4$ & $94.2 \pm 1.4$ & $94.2 \pm 1.4$ & $94.2 \pm 1.4$ & $92.3 \pm 1.4$ & 0.73 & 0.67 & 0.55 \\
\hline $\begin{array}{l}\text { Human-Animal- } \\
\text { Relationship }\end{array}$ & $54.8 \pm 3.6$ & $63.1 \pm 3.6$ & $57.6 \pm 3.6$ & $59.5 \pm 3.6$ & $56.3 \pm 3.6$ & $60.5 \pm 3.6$ & $64.4 \pm 3.5$ & $67.4 \pm 3.5$ & 0.12 & 0.08 & 0.83 \\
\hline Emotional State & $81.5 \pm 3.0$ & $80.0 \pm 3.0$ & $79.6 \pm 3.0$ & $77.2 \pm 3.0$ & $78.2 \pm 3.0$ & $75.4 \pm 3.0$ & $76.4 \pm 2.9$ & $73.9 \pm 2.9$ & 0.18 & 0.20 & 0.99 \\
\hline
\end{tabular}


Table 2.1.5 Selected results of Welfare Quality ${ }^{\circledR}$ assessments at indicator level at the end of the pasture (visit 1, summer 2014) and barn season (visit 2, winter 14/15) of dairy farms with > 10 hours (G1), 6 - 10 hours (G2), < 6 hours of pasture access/day (G3) or without pasture access (G4) (LS Means)

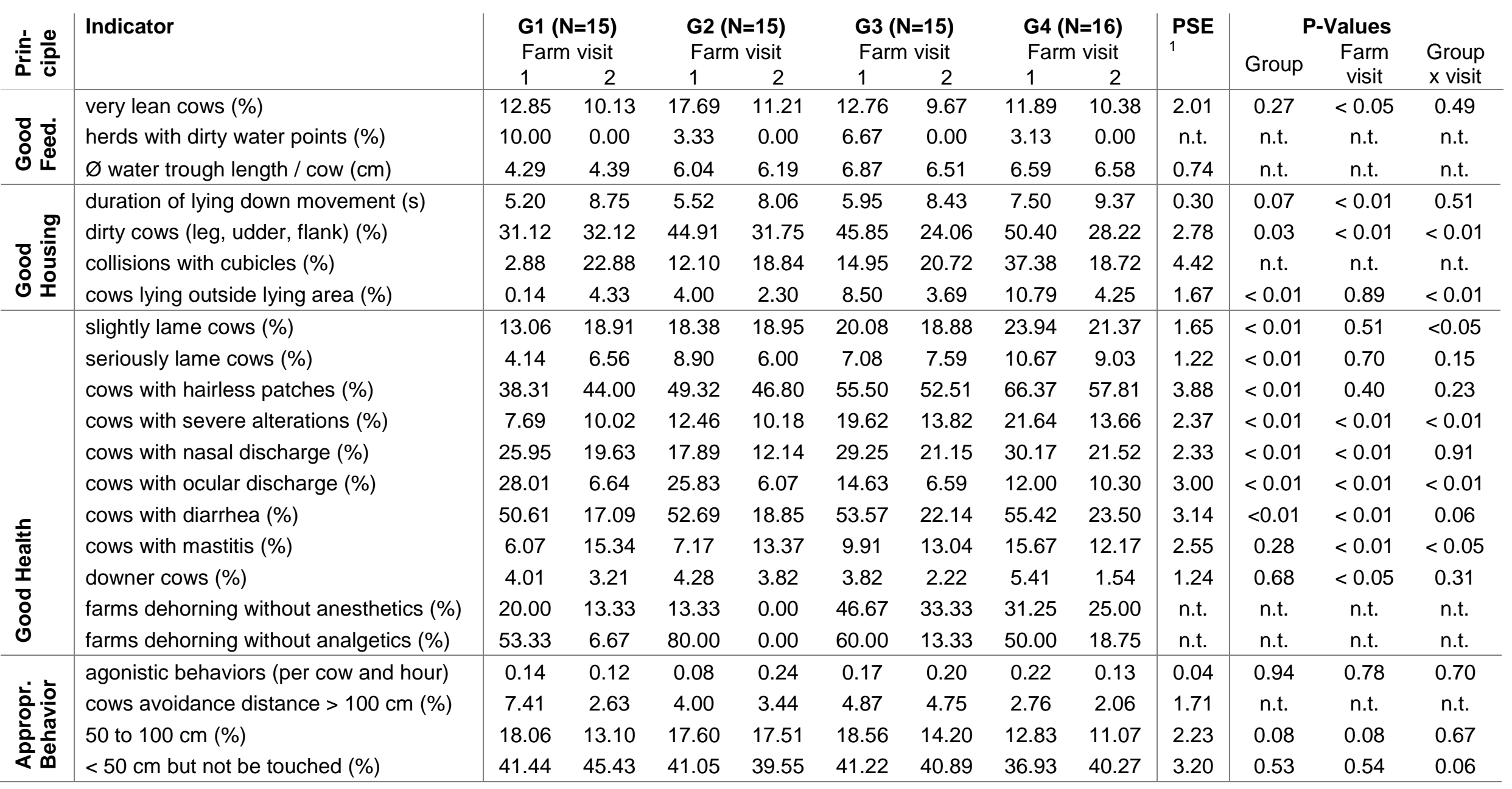

${ }^{1} \mathrm{PSE}=$ pooled standard error; n.t. $=$ not tested owing to lack of fulfilment of model assumptions. 
In $G 1$, fewest animals were lying outside their designated lying area in summer $(P<0.01)$. Of the 45 farms with pasture access, 31 farms were assessed on the pasture during the summer months. Thus, the indicators lying outside their designated lying area and collisions with housing equipment could be compared to G4 for the summer months, but are not convincing due to lacking cubicles on pasture. During the winter period, there was no difference observed between groups for this indicator. The same was valid for the indicator collisions with housing equipment.

The prevalence of slightly lame animals was characterized by an interaction of group and visit $(P<0.05)$, whereas it was lower on both visits in groups that provided pasture access in comparison with G4. Seriously lame animals were more often found on G4- and least on G1farms $(P<0.01)$. Similarly, animals with hairless patches and animals with severe alterations were observed at higher prevalence in $G 3$ and $G 4(P<0.01)$, without differences between visits $(P>0.05)$.

Nasal discharge occurred more often in summer than in winter months $(P<0.01)$ and more often in $G 3$ and $G 4$ than in $G 2(P<0.01)$. The interaction of group and visit affected the percentage of animals with ocular discharge $(P<0.01)$. In summer, $G 1$ and $G 2$ had a higher percentage of animals with ocular discharge than G3 and G4. Independent of the group, more than half of the animals were found with diarrhea in summer and approximately one fifth in winter. With increasing pasture access the prevalence of diarrhea decreased. Apart from G4, the mastitis rate was lower in summer than in winter $(P<0.05$ - group * farm visit effect). In summer, the prevalence was the lower the more pasture access was provided $(P<0.05$ - Posthoc tests). In all groups anesthetics and analgesics were used more often at the second visit than at the first visit in summer months.

Assessments of the indicators hampered respiration, frequency of coughing, vulvar discharge, mortality and dystocia showed a very low frequency at both visits ( $<4 \%$ of the cows). None of the indicators related to the principle appropriate behavior was observed with an effect of group or farm visit $(P>0.05)$. The frequency of agonistic behaviors was very low in all four groups. Alike, only a small proportion of the animals had an avoidance distance of over $100 \mathrm{~cm}$. Most of the animals showed an avoidance distance of under $50 \mathrm{~cm}$ or could be touched by the assessor. Up to now, the criterion expression of other behaviors is only based on pasture access. Given by the fact, that an according score for pasture access only could be reached when farms provide at least six hours of pasture access a day, as it was the case for G1 and G2 but not G3, this indicator was excluded from further calculations.

In addition to the parameters of the Welfare Quality ${ }^{\circledR}$ protocol, the cubicle design was assessed. Whether a farm had deep-bedded cubicles or cubicles with rubber mats affected 
several measures. The percentage of seriously lame animals ( $8.81 \pm 0.58$ vs. $6.19 \pm 0.66$, $P<0.01)$ and animals with a very lean body condition (13.22 \pm 1.16 vs. $10.93 \pm 1.24, P<0.05)$ was higher for cubicles with rubber mats than on farms with deep-bedded cubicles. More hairless patches $(59.19 \pm 2.40$ vs. $43.46 \pm 2.50, P<0.05)$ and more lesions and swellings (17.42 \pm 1.14 vs. $9.86 \pm 1.29, \mathrm{P}<0.01$ ) were found when the animals were housed in barns with rubber mats equipped cubicles instead of deep-bedded cubicles. For cubicles with rubber mats, there was a higher percentage of animals with dirty flanks than for those with deepbedded cubicles $(49.25 \pm 2.27$ vs. $32.76 \pm 1.29, P<0.05)$.

\section{Discussion}

The purpose of this study was to assess the effect of pasture access on welfare in conventional dairy farms using WQP as a holistic overall on-farm assessment tool. Consequently, farms were classified by their daily duration of pasture access and compared to farms without pasture access. The high variation in herd size as well as milk yield within all the groups emphasizes the representativeness of the study.

\section{Overall assessment}

It has to be emphasized that the scores for access to pasture were not considered, so that the maximum overall score a farm could reach was not 100 , but 88 points. Following, farms could still be classified as "excellent". The fact, that none of the farms received the classification "excellent" or "not classified" widely agrees with other studies. For example, POPESCU et al. (2014) assessed dairy farms with loose and tie-stall housing and could not classify any farm in these categories. In another study DE VRIES et al. (2013) did not find either any "excellent" farm. ANDREASEN et al. (2013) classified approximately half of the farms as "acceptable" (20 farms) and another half as "enhanced" (22 farms), while only one was "not classified". To a certain extent this emphasizes the representativeness of the present study. However, given that variations in our as well as in other studies of the overall score are very limited, it seems that the "excellent" classification is too high for those farms studied until now.

Holistic welfare assessments using the WQP of dairy cows in different housing systems are still rare. Other studies only used certain welfare or health measures and thus hardly enable comparisons with WQP results. For example, BUROW et al. (2013a) investigated the welfare of dairy cows with another multi-dimensional research method to compare pasture grazing and whole year indoor housing. Similar with the results of the present study, the welfare state of the cows was better during summer grazing than during winter indoor housing. The authors related enhanced welfare with an increase in daily hours on pasture in the summer months. 
Considering the clear preference of high-yielding dairy cows for pasture (CHARLTON et al., 2011; MOTUPALLI et al. 2014), it becomes obvious that efficient pasturing systems are feasible to improve welfare of dairy cows during the pasturing period.

\section{Principle Good Feeding}

The present findings are in agreement with BUROW et al. (2013a) who found thinner body conditions in pasturing cows during summer, compared with winter months, when assessing 41 Danish dairy farms with cubicle housing and access to pasture for at least 120 days/ year, for at least five hours daily. In the present study, highest variations of the BCS between summer and winter were noted in groups with access to pasture (G1, G2 and G3). This also supports findings of MULLER (2003), who proposed that pasturing results in reduced body condition and negative effects on reproduction and performance. Even when fed high quality pasture and high amounts of concentrate, high yielding cows showed a low BCS at the end of the pasture season. Likewise, with additional feeding of TMR, cows on pasture could not reach an optimal BCS at calving. WASHBURN et al. (2002) and HERNANDEZ-MENDO et al. (2007) also reported that pasturing is associated with problems for high yielding cows, especially in terms of body condition.

Problems with body condition can be mainly explained by suboptimal pasture management or by the use of the high yielding and at the same time high-quality feed requiring HolsteinFriesian breed, which is not optimally adapted to pasture feeding (STEINWIDDER and STARZ, 2006; THOMET et al., 2014). Consequently, pasturing systems for these animals require optimal feed supplementations, while pasture quality has to be maintained high. The fact that there was no effect of pasturing on the body condition, which was worse in summer compared with winter, might be, on the one hand, explained by suboptimal environmental conditions, especially heat stress conditions, during summer months in G4 and, on the other hand, by pastures that do not meet the requirements of the high-yielding cows in the pasture groups.

Though intensive pasturing enforces activity of the cows, groups with more than six hours/ day pasture access (G1 and G2) reached yields of more than $8900 \mathrm{~kg}$ ECM per lactation. Farms without pasture access (G4) showed an approximately $1000 \mathrm{~kg}$ higher milk yield. It remains questionable whether a reduced milk yield because of intensive pasturing with a potentially lower susceptibility to metabolism-related diseases, is more acceptable in terms of welfare as well as the economic reasons of high milk yield.

\section{Principle Good Housing}

Within the principle Good Housing there is still no indicator for the criterion thermal comfort in the WQP. However, heat stress conditions during summer months may impact cows' welfare 
on pasture and alike in barns. As previously reported by CHARLTON et al. (2011), cows preferred to stay on pasture as heat stress conditions intensified.

It has to be considered that the assessment of the lying conditions, generally took place on pasture in G1, G2 and G3 at the first visit. Lying conditions are supposed to be more appropriate on the pasture than in cubicles, where lying and resting is impeded to different degrees (KROHN and MUNKSGAARD, 1993). The principle Good Housing did not differ between the four groups when only the winter months were taken into account. Thus, it can be assumed that better scores for Good Housing for the groups with pasture access were mainly attributed to the pasture, next to other factors such as the flooring, cleanliness of floors and cubicles or cubicle design.

\section{Principle Good Health}

This study as well as previous studies of HERNANDEZ-MENDO et al. (2007) and CORAZZIN et al. (2010) indicated, that pasture access in summer has a significant positive effect on lameness and can help the cows to recover hoof and leg injuries from the barn season. The positive effect of pasture on lameness may be related to the prevention of strained joints, due to the soft ground. Concrete, hard surface leads to excessive growth of poor claw horn and stressed joints (ALGERS et al., 2009). Moreover, the cows have more space per animal and non-slippery surface on the pasture, compared to the barn, for more appropriate movements (ALGERS et al., 2009). Comparable to this study, results of decreasing integument alterations, hair loss, lesions and swellings with increasing intensity of pasture were also demonstrated by BuRow et al. (2013b). Cows with three to nine hours on pasture showed 2.2 times and cows with nine to 21 hours showed 4.8 times lower probability of integument alterations, than cows without access to pasture.

Similar observations were made with lower incidences of hair loss and severe skin alterations with increasing pasturing duration. Comparably, HASKELL et al. (2006) and RUTHERFORD et al. (2008) found more frequent hock and knee injuries for cows with no or limited access to pasture. Similarly, CORAZZIN et al. (2010) found a significant positive effect on injuries, when cows had access to pasture in the summer months, compared to housing in tie-stall barns in winter. Reduced evidence of minor and severe injuries can be mainly explained by the soft underground when lying down on pasture and excessive space per animal. In cubicles, there is a higher risk of injuries compared to the pasture, due to collisions with the barn interior or due to abrasions of tarsal joints on rubber mats (WECHSLER et al., 2000).

In terms of cubicle design, ZÄHNER et al. (2009) showed that cows in cubicle systems with soft lying mattresses or rubber mats had significantly higher incidence of hairless patches and scabs, swellings or wounds at tarsal joints, than cows in cubicle systems with deep bedding. 
In agreement, less hairless patches and less lesions and swellings were found in the present study for animals in barns with deep-bedded cubicles instead of cubicles with rubber mats. BRENNINKMEYER et al. (2013) indicated that a provision of deep bedding cubicles can prevent hock lesions, too. The authors associated a high prevalence of hock lesions with a high prevalence of lameness and suggested the provision of cubicles with deep-bedded materials to improve both hock lesions and lameness.

By studying lame dairy cows and observing a higher reluctance to change position on the rubber mats, compared to sand-bedded cubicles, BAK et al. (2016) demonstrated a better lying comfort of deep bedding cubicles. To sum up, deep-bedded cubicles provide a more comfortable lying surface compared with rubber mats or soft mattresses and therefore should be favored for a higher animal welfare.

With regard to the indicator diarrhea, it remains questionable whether loose watery manure, which can on the one hand be caused by diets without appropriate crude fiber contents or on the other hand by excessive protein contents of the pasture grass, should be classified - as done in the WQP - on the same level with the diarrheal disease caused by bacterial or viral infection. The prevalence of diarrhea was twice as high in summer than in winter in all four groups. CORAZZIN et al. (2010) and BuROW et al. (2013a) showed also worse faeces consistency during the summer months. Contrary, the group without pasture access (G4) showed a higher percentage of diarrhea in both farm visits, compared to the groups with pasture access. Thus, frequent occurrence of diarrhea cannot only be explained with pasture grazing. Another reason might be the high amount of concentrate feeding. The critical threshold for the indicator diarrhea, as stated in the WQP (> $6.5 \%$ of the herd), was exceeded by all farms in this study. This might indicate that all assessed farms should take care to prevent diarrhea prospectively.

WHITE et al. (2002) figured out that lactating cows without access to pasture showed a higher incidence of mastitis. Moreover, WASHBURN et al. (2002) verified that cows without pasture access had 1.8 times as many clinical cases of mastitis and were eight times more frequently culled because of mastitis, compared to cows with access to pasture. Positive effects of pasturing in terms of mastitis incidence were also observed in this study.

In all groups, obviously more farms used anesthetics and analgesics for dehorning at the second visit, due to a decree from the Lower Saxony Ministry of Food, Agriculture and Consumer Protection. Following this decree, farmers must use anesthetics and analgesics for dehorning since June 2015. Even though this might have biased results to some degree, regulations were implemented at a comparable rate in all groups. 


\section{Principle Appropriate Behavior}

The principle is among others composed of the QBA, which can be referred as a reliable method for the assessment of an animal's behavior (WICKHAM et al., 2012), even though its inter- and intra-observer reliability, together with its association with physiological parameters, was recently queried by SANT'ANNA and PARANHOS da COSTA (2013). In addition, ANDREASEN et al. (2013) found only weak correlations of QBA and WQP measures. Accordingly, QBA was proposed to be unfeasible as a stand-alone welfare assessment. Alike, TUYTTENS et al. (2014) indicated that the observer bias influenced subjective grading in the QBA. Overall, differences between pasture groups or seasons in our study and other production systems in previous studies could not be verified by using QBA. Nevertheless, there is still no other validated method to assess multiple behavioral signals and behavioral expression of animals, which could substitute QBA in the protocol.

Following the WQP criterion expression of other behaviors, only farms which provide access to pasture for more than six hours per day receive a score dependent on days/year and hours/ day on pasture, farms with less than six hours pasture access per day receive zero points. Weighting factors for pasturing are high, which is demonstrated by the fact that farms without pasture can reach a maximum of 88 out of 100 points in the WQP. This rating is justified by the results of this present study, as farms with less than six hours pasture access per day showed almost no differences to the group without pasture access in all WQP-principles. Consequently, minimal pasture access of less than six hours/ day does not improve the welfare state of dairy cows. Especially, for the principles Good Health and Good Housing pasturing of more than six hours showed positive effects in summer months.

In conclusion, farms with an extended intensity of pasturing, with more than six hours pasture access per day, achieved better WQP evaluations at the end of the pasture season when compared to farms without pasturing. While pasture access positively affected several health and housing parameters, neither of the pasture groups showed a difference to farms with yearround indoor housing at the end of the barn season, in which cows of all groups were kept under similar conditions.

\section{Acknowledgements}

The study was supported by the Ministry for Science and Culture of Lower Saxony (MWK) within the collaborative research project SAM, Analysis of Dairy Production: Grazing versus Indoor Housing of Dairy Cows, Support Code: ZN 2864. Furthermore, the authors would like to acknowledge Daniel Gieseke for his support during data collection and indeed the farmers who took part in the study. 


\section{References}

Algers, B., G. Bertoni, D. Broom, J. Hartung, L. Lidfors, J. Metz, L. Munksgaard, T.N. Pina, P. Oltenacu, J. Rehage and J. Rushen (2009): Scientific report on the effects of farming systems on dairy cow welfare and disease. Report of the Panel on Animal Health and Welfare. Annex to the EFSA Journal 1143, 114-284.

Andreasen, S., F. Wemelsfelder, P. Sandøe and B. Forkman (2013): The correlation of Qualitative Behavior Assessments with Welfare Quality ${ }^{\circledR}$ protocol outcomes in on-farm welfare assessment of dairy cattle. Applied Animal Behaviour Science 143, 9-17.

Bak, A.S., M.S. Herskin and M.B. Jensen (2016): Effect of sand and rubber surface on the lying behavior of lame dairy cows in hospital pens. Journal of Dairy Science 99(4), 28752883.

Brenninkmeyer, C., S. Dippel, J. Brinkmann, S. March, C. Winckler and U. Knierim (2013): Hock lesion epidemiology in cubicle housed dairy cows across two breeds, farming systems and countries. Preventive Veterinary Medicine 109, 236-245.

Burow, E. (2012): Welfare of dairy cows in Danish summer grazing herds. Public PhD defence, Aarhus University, Aarhus, Denmark.

Burow, E., T. Rousing, P.T.N. Thomsen, D. Otten and J.T. Sørensen (2013a). Effect of grazing on the cow welfare of dairy herds evaluated by a multidimensional welfare index. Animal 7(5), 834-842.

Burow, E., P.T. Thomsen, T. Rousing and J.T. Sørensen (2013b): Daily grazing time as a risk factor for alterations at the hock joint integument in dairy cows. Animal 7(1), 160-166.

Charlton, G.L., S.M. Rutter, M. East and L.A. Sinclair (2011): Preference of dairy cows: Indoor cubicle housing with access to a total mixed ration vs. access to pasture. Applied Animal Behaviour Science 130(1), 1-9.

Coignard, M., R. Guatteo, I. Veissier, A. de Boyer des Roches, L. Mounier, A. Lehébela und N. Bareille (2013): Description and factors of variation of the overall health score in French dairy cattle herds using the Welfare Quality ${ }^{\circledR}$ assessment protocol. Preventive Veterinary Medicine 112, 296-308.

Corazzin, M., E. Piasentier, S. Dovier and S. Bovolenta (2010): Effect of summer grazing on welfare of dairy cows reared in mountain tie-stall barns. Italian Journal of Animal Science 9, 304-312.

De Vries, M., E.A.M. Bokkers, G. van Schaik, R. Boltreau, B. Engel, T. Dijkstra and I.J.M. de Boer (2013): Evaluating results of the Welfare Quality multi-criteria evaluation model for classification of dairy cattle welfare at the herd level. Journal of Dairy Science 96, 1-10.

Gieseke, D., C. Lambertz, I. Traulsen, J. Krieter and M. Gauly (2014): Beurteilung von Tiergerechtheit in der Milchviehhaltung - Evaluierung des Welfare Quality ${ }^{\circledR}$ Protokolls. Züchtungskunde 86(1), 58-70. 
Haskell, M.J., L.J. Rennie, V.A. Bowell, M.J. Bell and A.B. Lawrence (2006): Housing system, milk production, and zero-grazing effects on lameness and leg injury in dairy cows. Journal of Dairy Science 89, 4259-4266.

Hernandez-Mendo, O., M.A.G. von Keyserlingk, D.M. Veira and D.M. Weary (2007): Effects of pasture on lameness in dairy cows. Journal of Dairy Science 90, 1209-1214.

Krohn, C.C. and L. Munksgaard (1993): Behaviour of dairy cows kept in extensive (loose housing/pasture) or intensive (tie stall) environments. Applied Animal Behavior Science $37,1-16$.

Leisen, E. (2014): Weidebasierte Milchviehhaltung in Deutschland. Grasland- und weidebasierte Milchproduktion, Mitteilungen der Arbeitsgemeinschaft Grünland und Futterbau Band 16, Internationale Weidetagung (eds Reidy B, Gregis B and Thomet P), 98-101. Zollikofen, Switzerland.

Leithold, A., E. Ofner-Schröck and A. Preinerstorfer (2011): Evaluierung von ÖPUL Fördermaßnahmen. Proceedings of the conference Diversifizierung versus Spezialisierung in der Agrar- und Ernährungswirtschaft, 21. Annual conference of the Austrian association of agronomy, 4.-6.10.2011, Bolzano, Italy, 65-66.

Motupalli, P.R., L.A. Sinclair, G.L. Charlton, E.C. Bleach and S.M. Rutter (2014): Preference and behavior of lactating dairy cows given free access to pasture at two herbage masses and two distances. Journal of Animal Science 92(11), 5175-5184.

Muller, L.D. (2003): Pasture, body condition and reproduction. Proceedings of conference Nutrition of dairy cows on pasture-based systems, 31.03.2003, Grantville, Pennsylvania, United States, 79-81.

Olmos, G., L. Boyle, A. Hanlo, J. Patton, J.J. Murphy and J.F. Mee (2009): Hoof disorders, locomotion ability and lying times of cubicle-housed compared to pasture based dairy cows. Livestock Science 125, 199-207.

Popescu, S., C. Borda, E.A. Diugan, M. Niculae, S. Razvan and C.D. Sandru (2014): The effect of the housing system on the welfare quality of dairy cows. Italian Journal of Animal Science 13(1), 15-22.

Reijs, J., C. Daatselaar, J. Helming, J. Jager and A. Beldman (2013): Grazing dairy cows in north-west Europe. LEI Report 2013-001. LEI Wageningen UR, The Hague, the Netherlands.

Rutherford, K.M.D., F.M. Langford, M.C. Sherwood, L. Jack, A.B. Lawrence and M.J. Haskell (2008): Hock injury prevalence and associated risk factors on organic and nonorganic dairy farms in the United Kingdom. Journal of Dairy Science 91, 2265-2274.

Sant'Anna, A.C. and M.J.R. Paranhos da Costa (2013): Validity and feasibility of qualitative behavior assessment for the evaluation of Nellore cattle temperament. Livestock Science 157(1), 254-262. 
Steinwidder, A. and W. Starz (2006): Sind unsere Kühe für die Weide noch geeignet? Proceedings of "Freiland-Tagung", September 2006, University of Veterinary Medicine, Vienna, Austria, 37-43.

Thomet, P., S. Ineichen and H. Jörg (2014): Züchten von Kühen für eine effiziente graslandbasierte Milchproduktion. Proceedings of "Grasland- und weidebasierte Milchproduktion"; International pasture conference, August 2014, Zollikofen, Switzerland, 61-70.

Tuyttens, F.A.M., S. de Graaf, J.L.T. Heerkens, L. Jacobs, E. Nalon, S. Ott, L. Stadig, E. van Laer and B. Ampe (2014): Observer bias in animal behaviour research: can we believe what we score, if we score what we believe? Animal Behaviour 90, 273-280.

Van den Pol-van Dasselaar, A., A. de Vliegher, D. Hennessy, J. Isselstein, J.-L. Peyraud (2015): The Future of Grazing; Proceedings, Third Meeting of the EGF Working Group "Grazing". Wageningen, Wageningen UR (University \& Research centre) Livestock Research, Livestock Research Report 906.

Washburn, S.P., S.L. White, J.T.Jr. Green and G.A. Benson (2002): Reproduction, mastitis, and body condition of seasonally calved Holstein and Jersey cows in confinement or pasture systems. Journal of Dairy Science 85, 105-111.

Wechsler, B., J. Schaub, K. Friedli and R. Hauser (2000): Behaviour and leg injuries in dairy cows kept in cubicle systems with straw bedding or soft lying mats. Applied Animal Behaviour Science 69, 189-197.

Weinrich R, S. Kühl, A. Zühlsdorf and A. Spiller (2014): Consumer attitudes in Germany towards different dairy housing systems and their implications for the marketing of pasture raised milk. International Food and Agribusiness Management Review 17(4), 205-222.

Weiß, D. (2014): Imagewirkung von weidenden Kühen. Proceedings of "Grasland- und weidebasierte Milchproduktion"; International pasture conference, August 2014, Zollikofen, Switzerland, 43-48.

Welfare Quality (2012): Welfare Quality ${ }^{\circledR}$ assessment protocol for cattle applied to dairy cows. Welfare Quality® Consortium, Lelystad, Netherlands.

White, S.L., G.A. Benson, S.P. Washburn and J.T.J. Green (2002): Milk production and economic measures in confinement or pasture systems using seasonally calved Holstein and Jersey cows. Journal of Dairy Science 85, 62-104.

Wickham, S.L., T. Collins, A.L. Barnes, D.W. Miller, D.T. Beatty, C. Stockman, D. Blache, F. Wemelsfelder and P.A. Fleming (2012): Qualitative behavioral assessment of transportnaïve and transport-habituated sheep. Journal of Animal Science 90, 4523-4535.

Zähner, M., S. Schrade, W. Schaeren and J. Schmidtko (2009): "Wiederkäuer: Haltung und Gesundheit: Neue Materialien als Einstreu in Liegeboxen von Milchviehställen" 
Proceedings of the conference 10. science conference organic farming, 11.-13.02.2009, ETH Zurich, Switzerland, 50-53. 


\title{
2.2 Does access to pasture affect claw conformation and health in dairy cows?
}

\author{
L. Armbrecht ${ }^{1}$, C. Lambertz ${ }^{2}$, D. Albers ${ }^{3}$ and M. Gauly ${ }^{2}$ \\ ${ }^{1}$ Department of Animal Science, University of Göttingen, 37075 Göttingen, Germany \\ ${ }^{2}$ Faculty of Science and Technology, 39100 Bozen, Italy \\ ${ }^{3}$ Chamber of Lower Saxony, Field Testing Station for Grassland Management and \\ Cattle Farming, 26121 Oldenburg, Germany
}

\begin{abstract}
The aim of this study was to examine the effects of pasturing in dairy cows on claw conformation (claw length, hardness) and most common claw diseases. At claw trimming, a total of 240 Holstein-Friesian or Red-Holstein cows from 20 German farms were examined twice, at the end of pasture and barn season. All four claws of each cow were trimmed and examined on both appointments for examination. Farms were classified based on animals' pasture access during pasture season into: group 1 (G1) > 10 hours pasture access per day, group 2 (G2) 6 - 10 hours, group 3 (G3) < 6 hours and group 4 (G4) without pasture. Greater values for hardness were associated with lower scores (= prevalence * severity level) of sole ulcers, white line disease, sole haemorrhage, heel horn erosion and interdigital hyperplasia. In pasture groups heel horn erosion showed lower frequencies in summer compared to winter, while it was vice versa for G4. For G1 and G3 this was also valid for white line disease. Overall, pasture access had positive effects especially for claw diseases that are related to moist environments, although good free-stall design and claw trimming routine might have more influence on claw health.
\end{abstract}

\section{Introduction}

Lameness affects welfare and productivity of dairy cattle (ARCHER et al., 2010; HUXLEY, 2013) and after fertility and mastitis problems, claw diseases are the most common culling reason (WEBER et al., 2012). First, clinical signs of claw diseases can already have considerable effects on milk yield (AMORY et al., 2008; ARCHER et al., 2010). Besides, claw diseases cause severe pain and therefore have an impact on the welfare of the animals (WHAY et al., 1998; RUSHEN et al., 2007). As a consequence of diseased claws, lameness leads also to reduced fertility (HERNANDEZ et al., 2001; GABARINO et al., 2004). Claw diseases are multifactorial, influenced by factors such as housing, feeding, hygienic conditions, body condition of the animal, claw horn quality and immune defence (EILERS, 2008). On average, 20 to $25 \%$ of highyielding dairy cows become lame each year (MÜLLING and GREENOUGH, 2006). Therefore, it is 
questionable how the present, intensive husbandry systems, are adapted to the needs of dairy cows, which from their natural behaviors' point of view prefer softer walking alleys (ALGERS et al., 2009).

Factors in barns, associated with lameness or claw diseases, include slippery or abrasive floors (SOMERs et al., 2003; TELEZHENKO and BERGSTEN, 2005), hard cubicle bedding (KANSWOHL and SANFTLEBEN, 2006; ZäHNER et al., 2009; ITO et al. 2010), insufficient cleanliness of cubicle lying area (CHAPINAL et al., 2013) and short or narrow cubicle dimensions with unadjusted neck rails (SOGSTAD et al., 2005; DIPPEL et al., 2009). However, these issues can be neglected whenever cows are on pasture. Claw disorders are more likely on hard or concrete flooring than on natural ground surface like pasture, which has been shown by several studies (HASKell et al. 2006; HeRnANDEZ-MENDo et al. 2007; Algers et al. 2009; CoRAZZIN et al. 2010). CORAZZIN et al. (2010) indicated that housing cows for the whole year indoor, without pasture access, has a detrimental effect on foot and leg health. However, it is still unknown, how much time dairy cows have to spend on the pasture to gain positive effects. In addition, measurements of claw hardness during the pasture season compared to the barn season are very rare. Therefore, the aim of the present study was to investigate effects on claw health in relation to pasture access at differing intensity. During the study, claw length and hardness, as well as prevalence and severity of claw diseases were examined at the end of the pasture and barn season, respectively.

\section{Material and methods}

\section{Farm selection}

Data were collected from February 2015 to May 2016 on 20 conventional loose housing dairy farms located in Lower Saxony, Germany. The farms were selected by the chamber of agriculture in Lower Saxony according to typical and preferably equal herd sizes in this region that are sustainable and viable in the long term. A mostly equal distribution of herd size between the groups was intended before farms were selected. A total of 240 Holstein-Friesian cows were assessed twice. For each farm one investigation took place at the end of the pasture season (during summer months) and at the end of the barn period (during winter months). Farms were grouped by their intensity of pasture access during summer months into: group 1 (G1) > 10 hours pasture access per day, group 2 (G2) 6 - 10 hours, group 3 (G3) < 6 hours and group 4 (G4) without pasture. Pasture was provided for at least 120 days in G1, G2 and G3. Three farms were equipped with concrete solid floors in the barn (one farm in G2, G3 and G4, respectively), 17 farms with slatted floors. Cubicles were equipped with rubber mats (10 farms) or were deep-bedded (10 farms). Moreover, three farms had an outdoor exercise area in summer and winter (one farm in G1, G2 and G3, respectively). On nine of the farms, the farmer did the claw treatments by himself, on the other 11 farms it was done by a 
professional hoof care person. Three of these 11 farms performed a professional treatment every two or three months for selected animals of the herd. Eight farms performed a professional treatment two times a year for the whole herd.

\section{Animal selection}

For the present study, 12 animals on each farm were selected for detailed assessment prior to the farm visit. Out of these 12 cows per farm, four cows had to be at the beginning of lactation ( 1 - 150 days in milk (DIM)), four cows at mid-lactation (151 - 250 DIM) and four cows at the end of lactation (> 250 DIM). On each farm, at least two, but not more than five cows were in the first lactation. Furthermore, two to three cows were in the sixth lactation or higher. Within these defined classes the animals were chosen randomly, based on the latest milk yield recording data.

\section{Data collection}

On the selected animals, all four claws were assessed after pasture and barn season. Each animal was treated according to the requirements of functional claw care (HEILKENBRINKER et al., 2004). Following, at both hind claws of each animal, hardness was measured with a Shore-D hardness tester (Shore-D Hardness Tester HAT-6510D), based on the assessment of resistance force during pressing the measuring tip in the material to be investigated. The depth of penetration was calculated by the hardness tester with the previously known spring load resulting in the Shore-hardness on a scale from 0 (2.5 mm penetration depth) to 100 ( $0 \mathrm{~mm}$ penetration depth). The measures were executed on eight previously defined measuring points (Figure 2.2.1) at the medial and lateral claw, on the sole horn and the abaxial wall (based on BORDERAS et al., 2004).

The length of both hind medial claws was measured and claw diseases, based on a keycode of the German Agricultural Society (Deutsche Landwirtschafts-Gesellschaft, DLG) (LANDMANN et al., 2011), were assessed. This assessment scheme contains the assessment of different degrees of severity from one to three of the following diseases, which are described in detail in Table 2.2.1: Dermatitis digitalis (DD), Dermatitis interdigitalis (DID), Sole Haemorrhage (SH), Sole Ulcer (SU), Rusterholz Sole Ulcer (RSU), Toe Ulcer (TU), Heel Horn Erosion (HHE), Punctual Discoloration (PD), Wall Lesions (WL), Double Sole (DS), White Line Disease (WLD), Interdigital Hyperplasia (IH), Interdigital Phlegmon (PH), Horn Fissure (HF). 


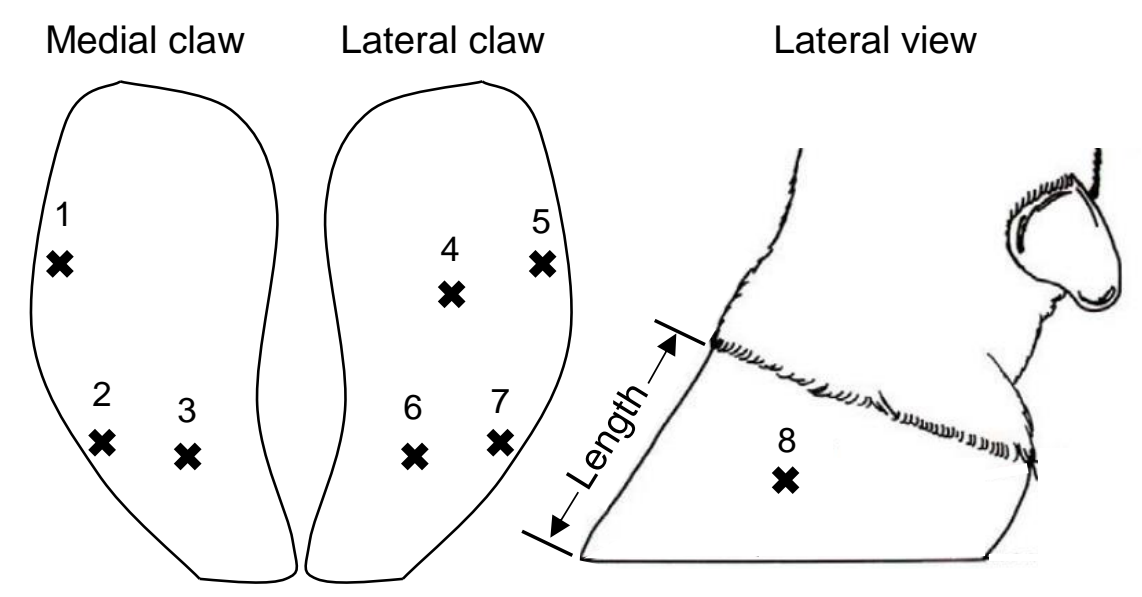

Figure 2.2.1 Measuring points for hardness at the medial (1-3) and lateral claw (4-7) on sole horn and abaxial wall (8) as well as measuring points for length on dorsal wall of the medial claw

\section{Statistical Analyses}

The following linear mixed effects model was used to analyse prevalence of all assessed diseases:

$$
Y_{i j k}=\mu+a_{i}+b_{j}+c_{i j}+d_{k}+e_{m}+\varepsilon_{i j k m}
$$

with $Y_{i j k}=$ specification of parameter, $\mu=$ overall average of sample, $a_{i}=$ fixed effect of group $i$ $(G 1, G 2, G 3, G 4), b_{j}=$ fixed effect of farm visit $j(1,2), c_{i j}=$ interaction between group $i$ and farm visit $j, d_{k}=$ fixed effect of lactation number $k(1-5), e_{m}=$ random effect of animal within farm $m$ (1-20) and $\varepsilon_{i \mathrm{ikm}}=$ residual error. All statistical analyses were computed with SAS, version 9.3 (Statistical Analysis Systems, Cary, NC, USA) using the GLIMMIX procedure. The animal within farm was defined as the statistical unit.

Results were considered statistically significant at a probability level of $\alpha<0.05$. Multiple pairwise differences between the four groups were assessed by applying the Bonferroni correction. Prevalence of assessed diseases was calculated in percent of affected cows out of the respective herd sample on each farm. These data were log-, sqrt- or arcsine-transformed prior to analysis, if normal distribution was not given. To avoid bias of the estimators, all mean values given in the results were calculated with the non-transformed data. For parameters without normal distribution, even after log-, sqrt- or arcsine-transformation, P-values were calculated with GLIMMIX assuming Poisson or negative-binomial distribution.

A cumulative score of each disease was calculated in order to consider prevalence in association with severity level. These scores were calculated for any assessed disease following $Y=\alpha^{*} 1+\beta^{*} 2+Y^{*} 3$ with $\alpha=$ mild affected claws, $\beta=$ moderate affected claws and $Y=$ severe affected claws. This means that for each cow, eight claws were taken into account 
for the diseases SH, SU, RSU, TU, PD, WL, DS and WLD and four claws for the diseases DD, DID, HHE and IH. Thus, each individual cow could be assessed with a maximum score of 24 (for diseases where all eight claws were scored) or 12 (for diseases where four claws were assessed). To calculate the least square means of the scores the procedure PROC MEANS was applied. Because of non-normal distribution even after transformation, P-values were calculated with the procedure PROC NPAR1WAY. With PROC CORR Spearman's correlations between single diseases were calculated.

\section{Results}

\section{Farm characteristics}

On average, herds sized 140 cows, ranging from 63 to 478 animals (Table 2.2.2). Mean ECM (energy corrected milk) yield was $9119 \mathrm{~kg}$. G1 with $8788 \mathrm{~kg}$ and G2 with $8799 \mathrm{~kg}$ had a lower ECM, compared to G3 with $9595 \mathrm{~kg}$ and G4 with $9294 \mathrm{~kg}(\mathrm{P}<0.05)$.

\section{Claw conformation}

As shown in Table 2.2.3, the length of the right and left hind claws indicated no differences between the groups, farm visits nor their interaction $(P>0.05)$. Mean values varied between 7.5 and $8.6 \mathrm{~cm}$. Medial sole hardness showed no significant differences between groups or farm visits, too. Lateral sole had greater mean Shore-D values in winter than in summer months $(P<0.01)$. The hardness of the medial and lateral wall differed significantly between the four groups $(P<0.05)$, whereas G2 and G4 showed the greatest Shore-D values of the four groups and a tendency to harder wall horns in winter compared with summer. G1 and G3 indicated contrary results with a tendency for harder wall horns in summer. G3 showed the lowest Shore$\mathrm{D}$ values of all four groups.

\section{Claw diseases}

The diseases wall lesions (4.97\%), interdigital phlegmon $(0.42 \%)$ and horn fissure $(1.25 \%)$ occurred very infrequently in all farms, so that they were not considered further in the following. Figure 2.2.2 shows the most prevalent diseases in percent of all assessed cows in the four different groups. Most frequently, HHE, WLD and SH were assessed in all groups. HHE was influenced by the interaction between group and farm visit $(P<0.01)$, as well as farm visits $(P$ $<0.01)$. Groups with pasture access had a higher prevalence of HHE in winter, compared to summer. In contrast, G4 showed an inverse relation with more HHE affected cows in summer. 
Table 2.2.1 Keycode for claw assessment of German Agricultural Society (DLG) (LANDMANN et al., 2011)

\begin{tabular}{|c|c|c|c|c|}
\hline Abbr. & Name & Severity "mild" & $\begin{array}{l}\text { Severity } \\
\text { "moderate" }\end{array}$ & Severity "severe" \\
\hline $\mathrm{SH}$ & $\begin{array}{l}\text { Sole } \\
\text { Hemorrhage }\end{array}$ & $\begin{array}{l}\text { Curve (concavity) of } \\
\text { dorsal wall and/ or } \\
\text { discoloration of sole up } \\
\text { to } 1 / 3\end{array}$ & $\begin{array}{l}\text { Curve (concavity) of } \\
\text { dorsal wall and/ or } \\
\text { discoloration of sole up } \\
\text { to } 2 / 3\end{array}$ & $\begin{array}{l}\text { Curve (concavity) of } \\
\text { dorsal wall and/ or } \\
\text { discoloration of sole up } \\
\text { to } 3 / 3\end{array}$ \\
\hline \multirow[t]{2}{*}{ WLD } & \multirow[t]{2}{*}{$\begin{array}{l}\text { White Line } \\
\text { Disease }\end{array}$} & \multicolumn{3}{|c|}{$\begin{array}{c}\text { Horn separation; dark colored fissures and/ or internal bleeding and/ or } \\
\text { cracking wall components }\end{array}$} \\
\hline & & $\begin{array}{l}\text { Extension up to } 1 / 3 \text { of } \\
\text { white line }\end{array}$ & $\begin{array}{l}\text { Extension up to } 2 / 3 \text { of } \\
\text { white line }\end{array}$ & $\begin{array}{l}\text { Extension up to } 3 / 3 \text { of } \\
\text { white line }\end{array}$ \\
\hline \multirow[t]{3}{*}{ WL } & \multirow{3}{*}{$\begin{array}{l}\text { Wall Lesions } \\
\text { (axial/ } \\
\text { abaxial) }\end{array}$} & \multicolumn{3}{|c|}{ Inflammatory defect } \\
\hline & & Up to $1.5 \mathrm{~cm}$ & Up to $2.5 \mathrm{~cm}$ & $>2.5 \mathrm{~cm}$ \\
\hline & & Superficial & $\begin{array}{l}\text { Starting channel } \\
\text { formation towards } \\
\text { coronary band }\end{array}$ & $\begin{array}{l}\text { Probably deeper } \\
\text { structure affected }\end{array}$ \\
\hline DS & Double Sole & $\begin{array}{l}\text { Extension up to } 1 / 3 \text { of } \\
\text { sole }\end{array}$ & $\begin{array}{l}\text { Extension up to } 2 / 3 \text { of } \\
\text { sole }\end{array}$ & $\begin{array}{l}\text { Extension up to } 3 / 3 \text { of } \\
\text { sole }\end{array}$ \\
\hline $\mathrm{HHE}$ & $\begin{array}{l}\text { Heel Horn } \\
\text { Erosion }\end{array}$ & $\begin{array}{l}\text { V-shaped grooves in } \\
\text { outlines }\end{array}$ & $\begin{array}{l}\text { V-shaped grooves } \\
\text { located over entire } \\
\text { width of claw }\end{array}$ & $\begin{array}{l}\text { Additionally: Heel Horn } \\
\text { swelling and/ or } \\
\text { inflammatory } \\
\text { alterations of dermis }\end{array}$ \\
\hline DID & $\begin{array}{l}\text { Dermatitis } \\
\text { interdigitalis }\end{array}$ & $\begin{array}{l}\text { Coating without } \\
\text { alterations of }\end{array}$ & $\begin{array}{l}\text { Damage of interdigital } \\
\text { dermis: Extension up }\end{array}$ & $\begin{array}{l}\text { Damage of interdigital } \\
\text { dermis: }\end{array}$ \\
\hline & & interdigital dermis & to length of $2 \mathrm{~cm}$ & $\begin{array}{l}\text { Extension over length } \\
\text { of } 2 \mathrm{~cm}\end{array}$ \\
\hline DD & $\begin{array}{l}\text { Dermatitis } \\
\text { digitalis }\end{array}$ & $\begin{array}{l}\text { First indications up to } \\
1.5 \mathrm{~cm} \text { diameter }\end{array}$ & $\begin{array}{l}1.5 \mathrm{~cm} \text { diameter up to } \\
2.5 \mathrm{~cm} \text { diameter }\end{array}$ & $>2.5 \mathrm{~cm}$ diameter \\
\hline \multirow[t]{2}{*}{ PD } & \multirow{2}{*}{$\begin{array}{l}\text { Punctual } \\
\text { Discoloration }\end{array}$} & \multicolumn{3}{|c|}{ Pressure point on Rusterholz position without perforation of sole horn } \\
\hline & & $\begin{array}{l}\text { Up to } 0.5 \mathrm{~cm} \text { diameter } \\
\text { (pea-size) }\end{array}$ & $\begin{array}{l}>0.5 \mathrm{~cm} \text { diameter } \\
\text { up to } 1.5 \mathrm{~cm} \text { diameter }\end{array}$ & $>1.5 \mathrm{~cm}$ diameter \\
\hline $\begin{array}{l}\text { SU, } \\
\text { RSU, } \\
\text { TU }\end{array}$ & $\begin{array}{l}\text { Sole Ulcer, } \\
\text { Rusterholz- } \\
\text { Sole Ulcer, } \\
\text { Toe Ulcer }\end{array}$ & $\begin{array}{l}\text { Up to } 1 \mathrm{~cm} \text { diameter } \\
\text { superficial damage of } \\
\text { dermis }\end{array}$ & $\begin{array}{l}>1 \mathrm{~cm} \text { diameter up to } \\
2.5 \mathrm{~cm} \text { diameter } \\
\text { partially: necrotic } \\
\text { alteration of dermis }\end{array}$ & $\begin{array}{l}>2.5 \mathrm{~cm} \text { diameter } \\
\text { severe necrotic } \\
\text { alterations }\end{array}$ \\
\hline $\mathrm{IH}$ & $\begin{array}{l}\text { Interdigital } \\
\text { Hyperplasia }\end{array}$ & No spreading & With spreading & $\begin{array}{l}\text { inflamed with/ without } \\
\text { spreading }\end{array}$ \\
\hline $\mathrm{HF}$ & Horn Fissure & $\begin{array}{l}\text { Not continuous from } \\
\text { coronary band to sole, } \\
\text { not penetrating to } \\
\text { dermis = superficial }\end{array}$ & $\begin{array}{l}\text { Continuous, not } \\
\text { penetrating }= \\
\text { superficial }\end{array}$ & $\begin{array}{l}\text { penetrating to dermis = } \\
\text { deep }\end{array}$ \\
\hline
\end{tabular}


Table 2.2.2 Characteristics (herd size, energy corrected milk yield (ECM), protein content and fat content, cubicle design) of 20 dairy farms with > 10 hours (G1), 6 to 10 hours (G2), $<6$ hours of pasture access/day (G3) or without pasture access (G4) of three years (20122015) (LS Means \pm Standard Error)

\begin{tabular}{|c|c|c|c|c|}
\hline $\begin{array}{c}\text { Farm } \\
\text { characteristics }\end{array}$ & $\begin{array}{l}\text { Group } 1 \\
(\mathrm{~N}=5)\end{array}$ & $\begin{array}{c}\text { Group } 2 \\
(\mathrm{~N}=5)\end{array}$ & $\begin{array}{c}\text { Group } 3 \\
(\mathrm{~N}=5)\end{array}$ & $\begin{array}{c}\text { Group } 4 \\
(N=5)\end{array}$ \\
\hline Herd size & $135^{\mathrm{a}}( \pm 24.78)$ & $125^{\mathrm{a}}( \pm 21.98)$ & $142^{\mathrm{a}}( \pm 28.34)$ & $157^{\mathrm{a}}( \pm 27.46)$ \\
\hline Range & $69-173$ & $63-243$ & $65-291$ & $63-478$ \\
\hline ECM (kg) & $8788^{a}( \pm 193)$ & $8799^{a}( \pm 180)$ & $9595^{b}( \pm 226)$ & $9294^{\mathrm{b}}( \pm 235)$ \\
\hline Range & 8257 - 9599 & $7984-10080$ & $9166-10911$ & $7778-10505$ \\
\hline Protein (\%) & $3.42^{a}( \pm 0.02)$ & $3.37^{b}( \pm 0.02)$ & $3.38^{\mathrm{ab}}( \pm 0.02)$ & $3.36^{b}( \pm 0.02)$ \\
\hline Range & $3.33-3.52$ & $3.21-3.49$ & $3.29-3.47$ & $3.28-3.46$ \\
\hline Fat (\%) & $3.96^{\mathrm{a}}( \pm 0.04)$ & $4.16^{b}( \pm 0.03)$ & $4.05^{a}( \pm 0.04)$ & $4.01^{\mathrm{a}}( \pm 0.04)$ \\
\hline Range & $3.70-4.20$ & $4.01-4.30$ & $3.96-4.17$ & $3.80-4.23$ \\
\hline $\begin{array}{l}\text { Deep-bedded } \\
\text { cubicles } \\
\text { (no. of farms) } \\
\text { Cubicles with }\end{array}$ & 2 & 2 & 2 & 4 \\
\hline $\begin{array}{l}\text { rubber mats } \\
\text { (no. of farms) }\end{array}$ & 3 & 3 & 3 & 1 \\
\hline
\end{tabular}

a,b Values within a row with different superscripts differ significantly at $P<0.05$.

As indicated in Figure 2.2.3, in G1 almost $60 \%$ of HHE affected claws were scored as mildly affected at the end of the pasture season, while only $36 \%$ in winter, whereas severity increased. In contrast, in G2, G3 and G4 mild HHE occurred more often in winter. Compared with the other groups, G1 showed the highest percentage of not with HHE affected claws in summer and G4 in winter.

For WLD significant differences only were indicated between summer and winter months $(P<0.05)$, with a higher prevalence of WLD in winter. However, G1 indicated a tendency $(P<0.1)$ to less WLD affected cows, compared to G4. For all groups WLD affected claws were predominantly scored as mildly severe at both farm visits. Moderate and severe scores represented almost $50 \%$ of the diseased claws in G2 during the pasture period. 
Table 2.2.3 Claw length (medial hind claws) and hardness (Shore-D of right and left hind claw) at the end of the pasture (summer) and barn season (winter) of dairy farms with $>10$ hours (G1), 6 to 10 hours (G2), < 6 hours of pasture access/day (G3) or without pasture access (G4), for 12 animals per farm/ farm visit (LS Means)

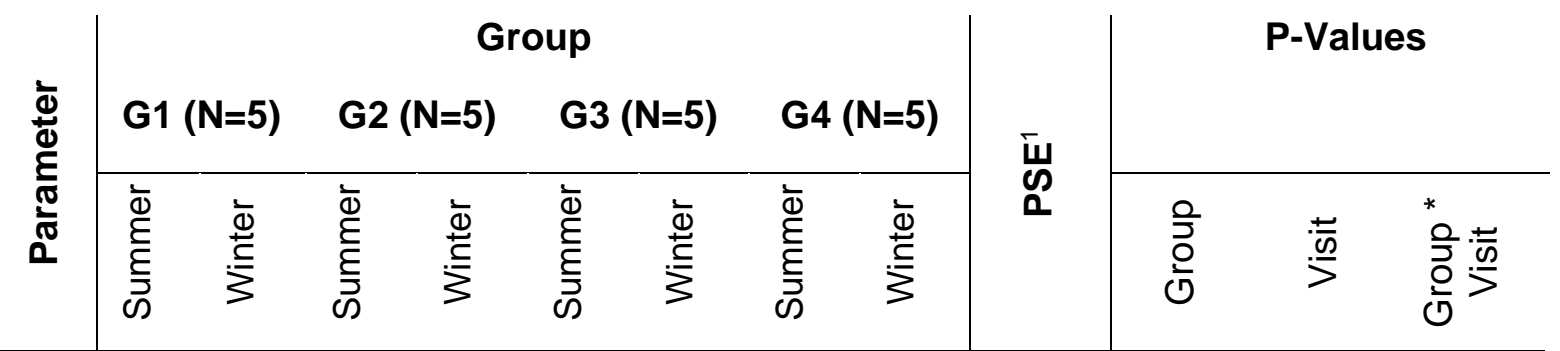

Claw length (cm)

\begin{tabular}{|c|c|c|c|c|c|c|c|c|c|c|c|c|}
\hline$\stackrel{5}{0}$ & 8.3 & 7.8 & 8.0 & 8.0 & 7.9 & 7.5 & 8.5 & 8.5 & \pm 0.09 & 0.52 & 0.56 & 0.89 \\
\hline $\begin{array}{l}\frac{\vec{L}}{.0} \\
\frac{0}{\pi}\end{array}$ & 8.3 & 7.7 & 8.2 & 8.1 & 8.0 & 7.6 & 8.6 & 8.4 & \pm 0.14 & 0.57 & 0.41 & 0.91 \\
\hline
\end{tabular}

\section{Hardness (Shore-D)}

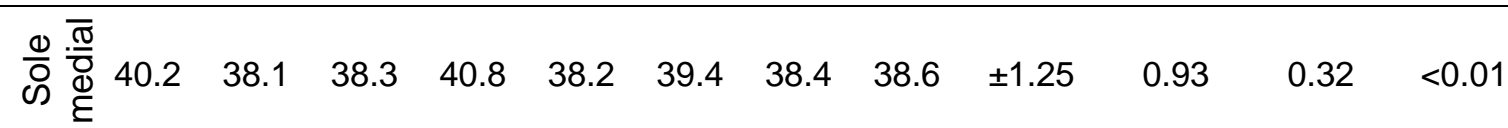

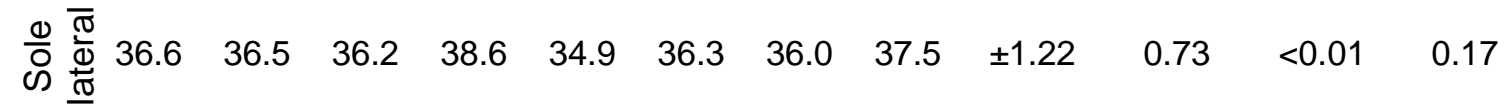

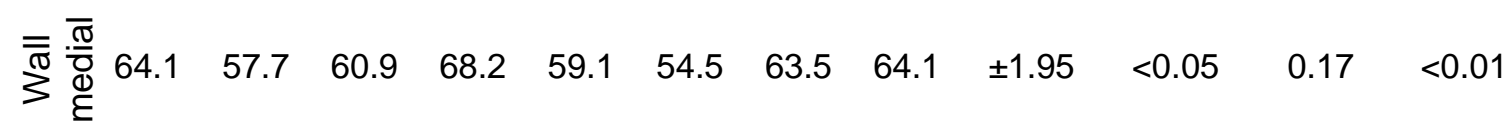

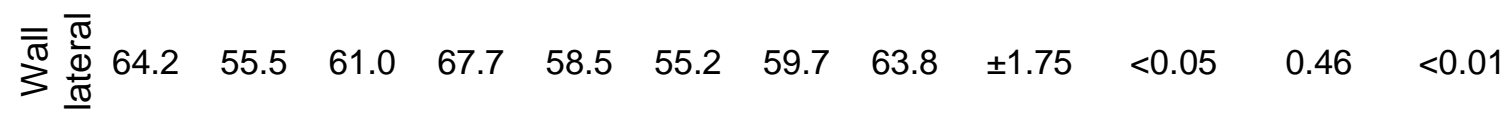

\footnotetext{
${ }^{1}$ Pooled Standard Error.
} 

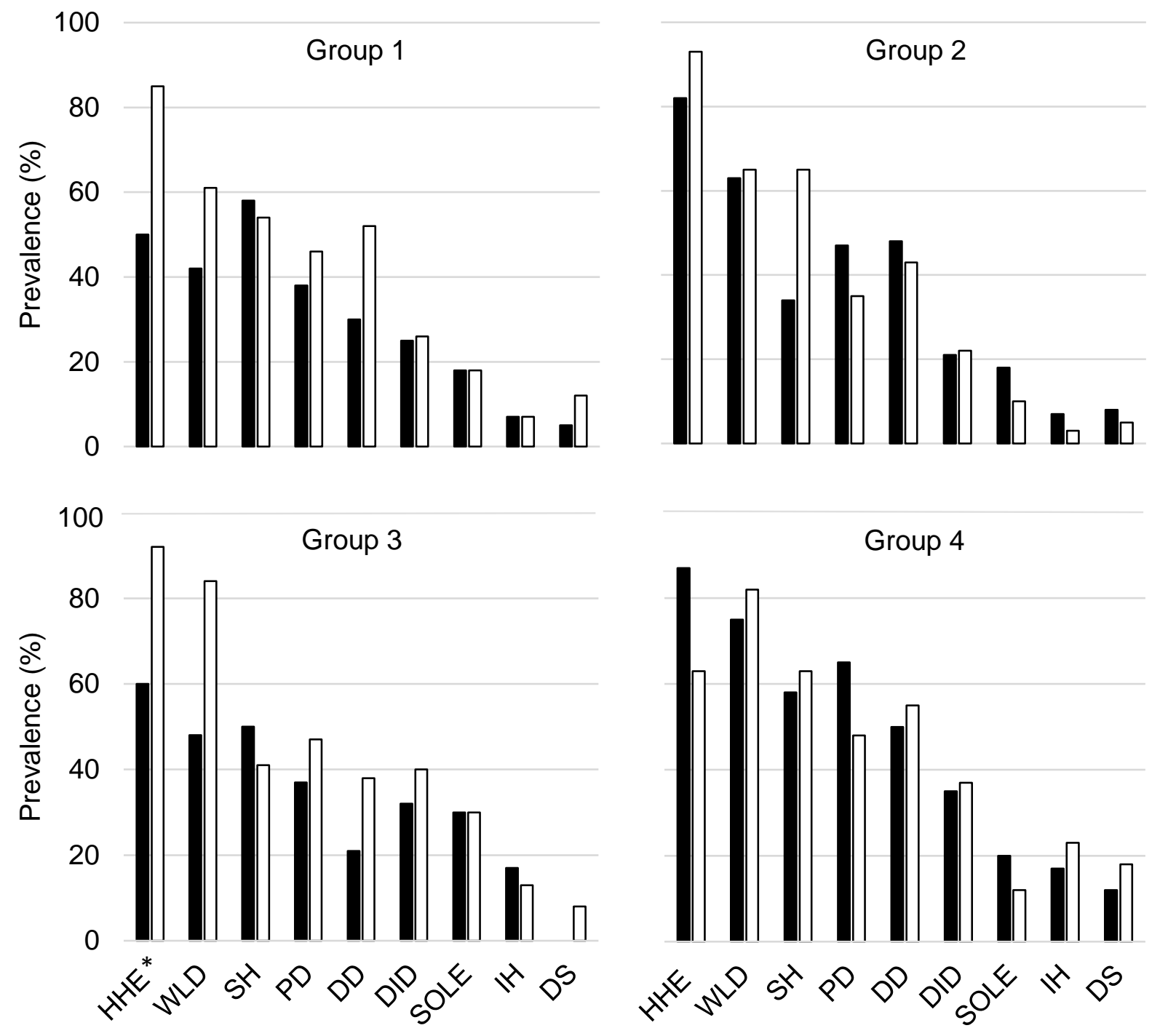

- Summer

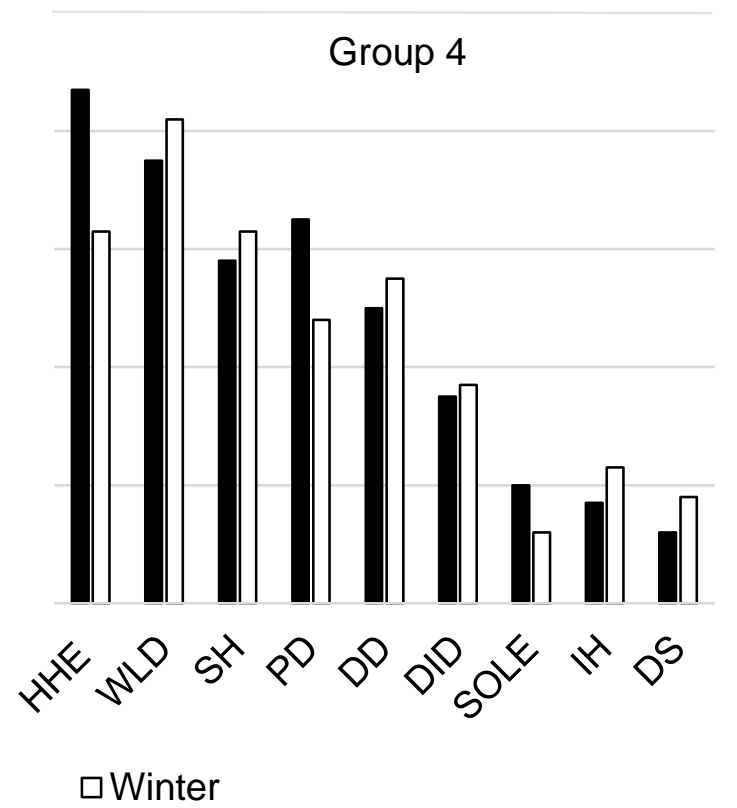

* Heel Horn Erosion (HHE), White Line Disease (WLD), Sole Hemorrhage (SH), Punctual Discoloration (PD), Dermatitis digitalis (DD), Dermatitis interdigitalis (DID), SOLE = Sole Ulcer (SU) + Rusterholz Sole Ulcer (RSU) + Toe Ulcer (TU), Interdigital Hyperplasia (IH), Double Sole (DS).

Figure 2.2.2 Prevalence of diseased cows at the end of the pasture (summer) and barn season (winter) of dairy farms with $>10$ hours (Group 1), 6 to 10 hours (Group 2), < 6 hours of pasture access/day (Group 3) or without pasture access (Group 4) (LS Means) 


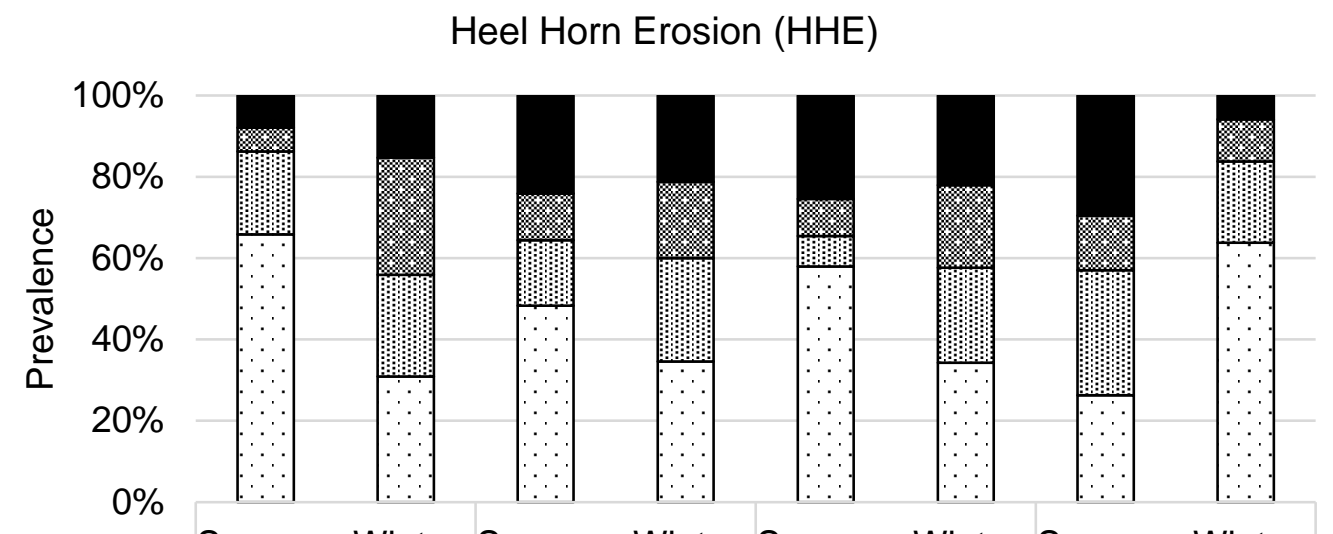

Summer Winter Summer Winter Summer Winter Summer Winter
Group 1
Group 2
Group 3
Group 4
$\square$ none 团mild $⿴$ moderate $\square$ severe
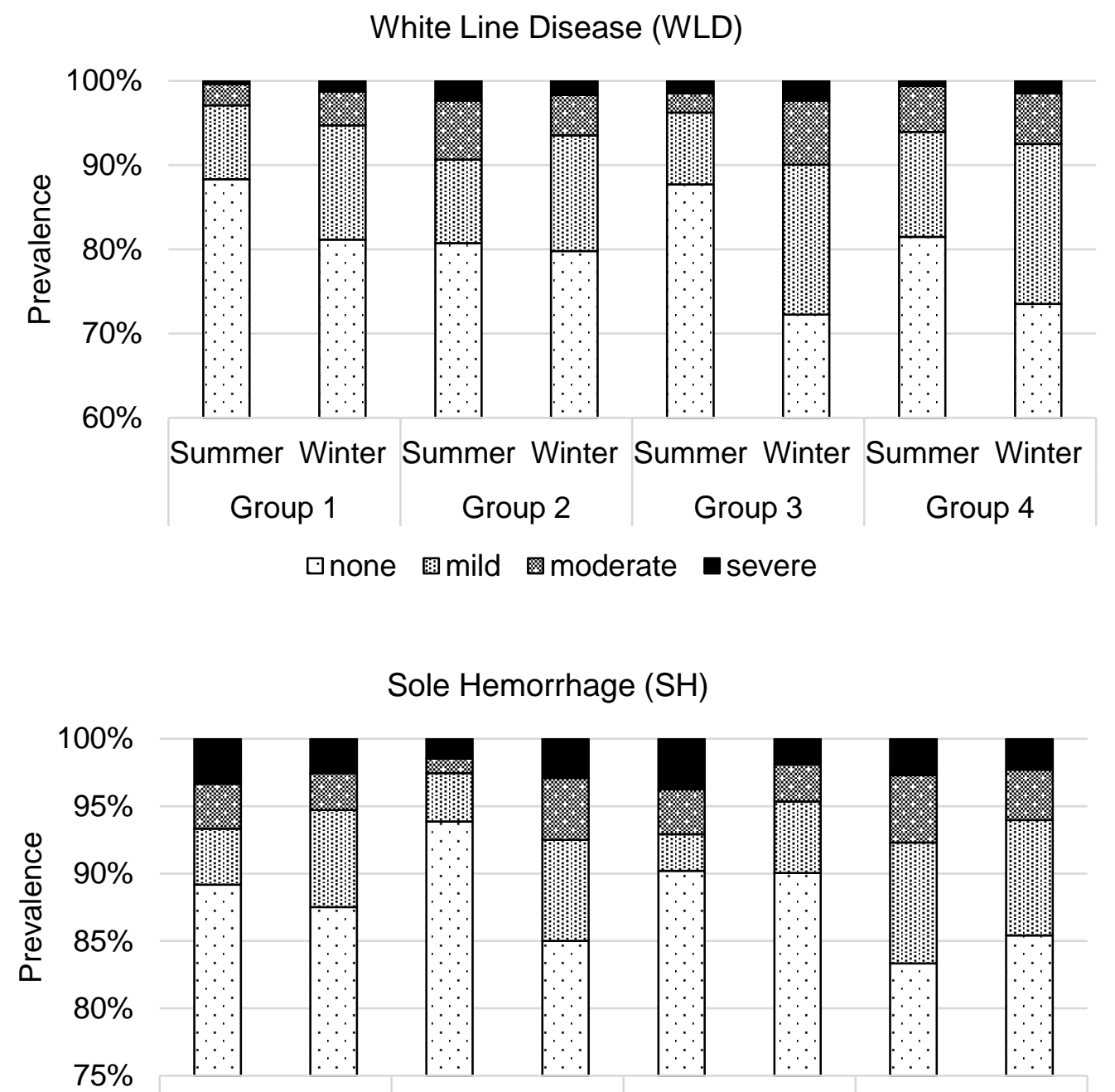

Summer Winter Summer Winter Summer Winter Summer Winter
Group 1
Group 2
Group 3
Group 4

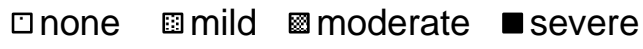




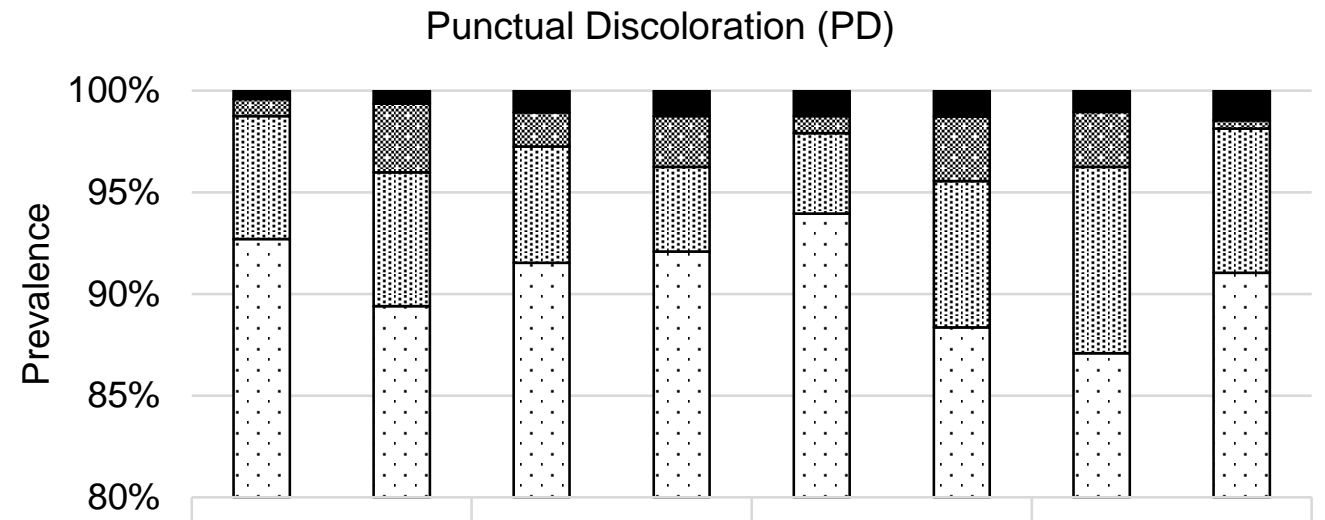

Summer Winter Summer Winter Summer Winter Summer Winter

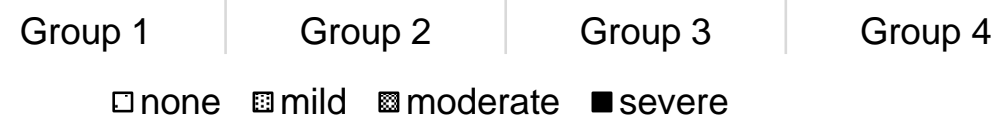

Dermatitis Digitalis (DD)

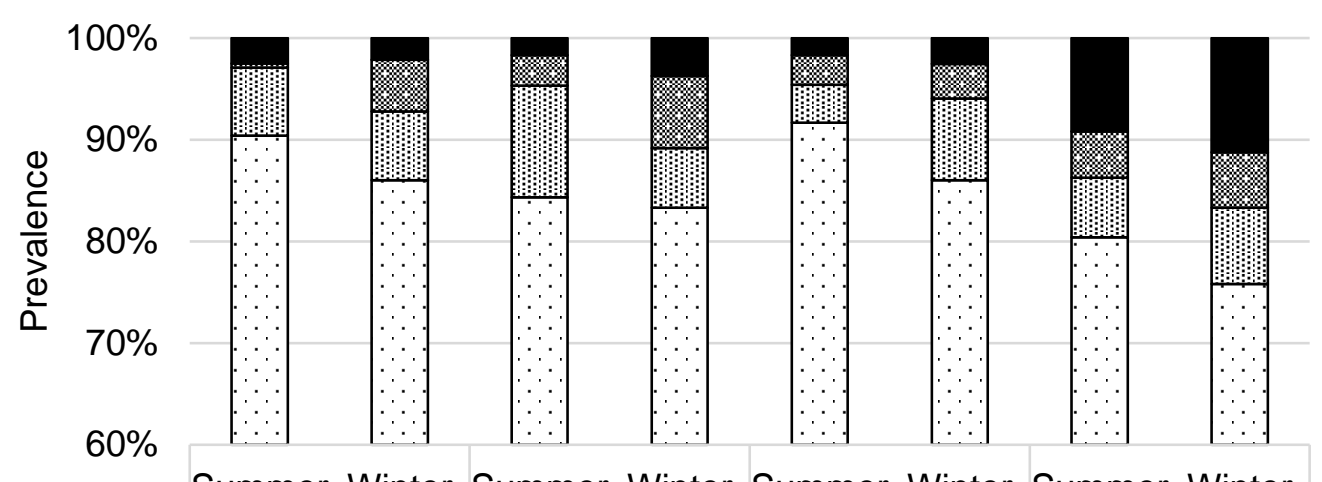

$$
\begin{array}{c|cc|c}
\text { Group 1 } & \text { Group 2 } & \text { Group 3 } & \text { Group 4 } \\
\text { unone } \text { 国mild } \text { 圆moderate } & \text { asevere }
\end{array}
$$

Dermatitis Interdigitalis (DID)

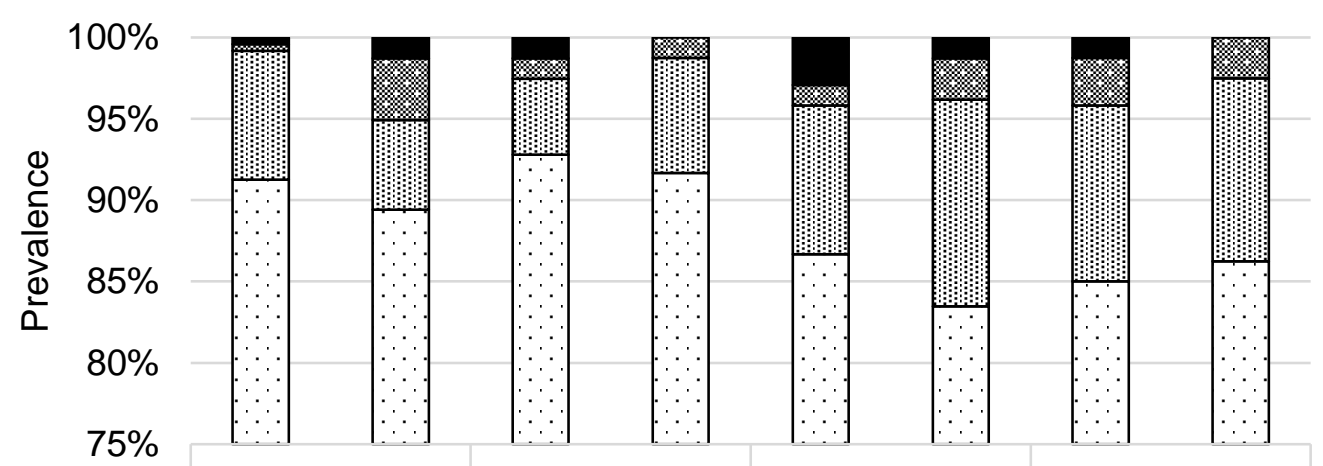

Summer Winter Summer Winter Summer Winter Summer Winter
Group 1
Group 2
Group 3
Group 4
anone 国mild 圈moderate asevere 


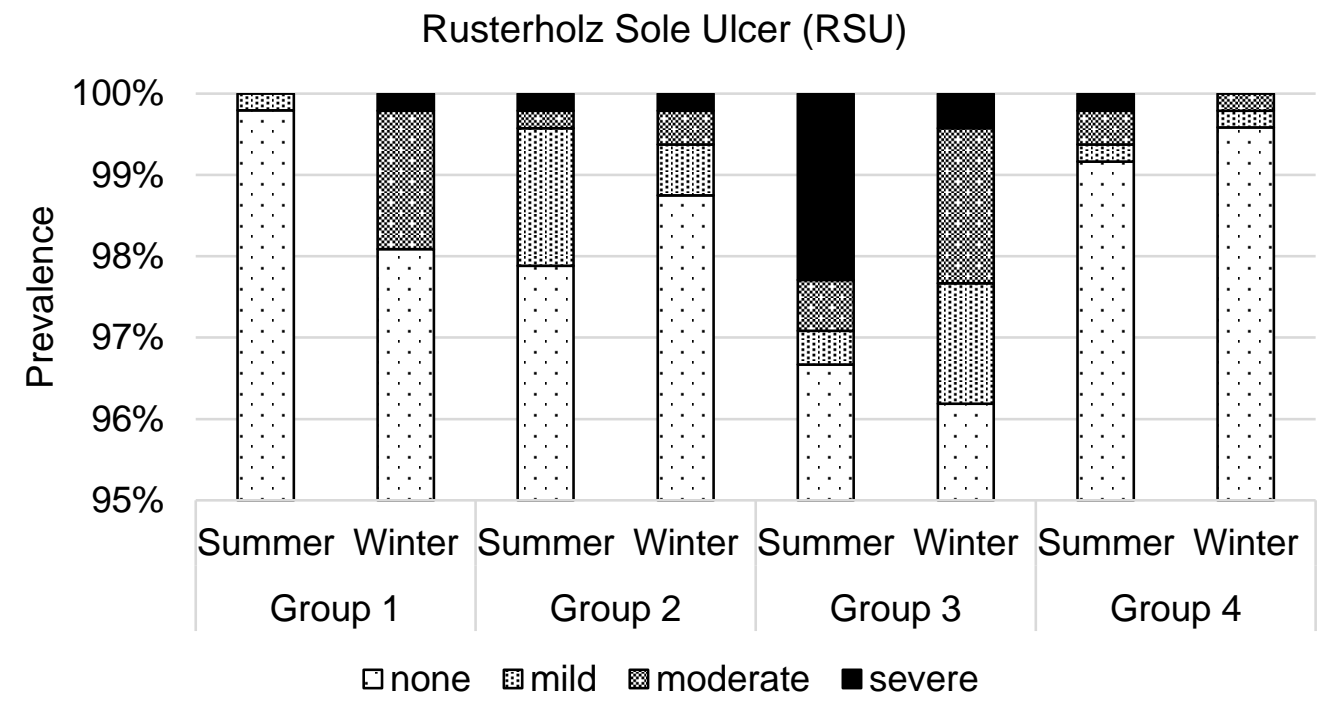

Figure 2.2.3 Prevalence of diseased claws of different severity (none, mild, moderate, severe) at the end of the pasture (summer) and barn season (winter) in farms with $>10$ hours (Group 1), 6 to 10 hours (Group 2), < 6 hours of pasture access/day (Group 3) or without pasture access (Group 4), for 12 animals per farm/ farm visit (LS Means)

Effects of group, farm visit or its interaction were not found on the prevalence for SH, PD, DD, DID and DS $(P>0.05)$. Moderate and severed SH appeared more frequently in $G 1, G 3$ and G4 in summer than in winter. In all groups, except for G2 in winter, PD was scored at $60 \%$ of the affected claws as mild. Groups with most pasture access (G1, G2) had higher prevalences of moderate and severe levels of PD during the barn than pasture season. With approximately $50 \%$ of the DD affected claws scored as severe, G4 was worse than the other groups in both farm visits. High variations were found in $\mathrm{G} 1$ and $\mathrm{G} 2$, where approximately $70 \%$ of DD affected claws were scored as mild in summer, but predominantly moderate in winter. $90 \%$ of the DID affected claws showed mild severity in G1 in summer, which increased in severity in winter. In the other groups more than $65 \%$ of the DID affected claws were scored as mild at both farm visits. In winter no severe DID affected claws were found in G2 and G4, though 15\% and 18\% of moderately affected, respectively.

For the three evaluated types of sole ulcer (SOLE), farm visits $(P<0.01)$ and its interaction $(P<0.05)$ had an effect. While $G 1$ and $G 3$ showed a similar prevalence in both farm visits, G2 and G4 were observed with lower prevalence at the end of the barn season. Rusterholz' sole ulcer (RSU) was the most frequent type of sole ulcer assessed in this study. Highest variations in severity level of RSU were found in G1. During the pasture season, all assessed RSU affected claws were classified as mild. Contrarily, affected claws were scored as moderate $(90 \%)$ or severe $(11 \%)$ in winter. G3 showed the most severe RSU affected claws $(69 \%)$ in summer, compared to the other groups. 
In G4 IH occurred more frequently in the winter, whereas groups with access to pasture, had a lower percentage of cows with $\mathrm{IH}$ during the winter $(\mathrm{G} 2, \mathrm{G} 3)$ or showed the same level of affected cows in both farm visits $(G 1)(P<0.05)$. Prevalence of IH differed not between groups or farm visits $(P>0.05)$. Due to low prevalences of SU, TU, IH and DS these diseases were not further specified.

\section{Cumulative disease scores}

As shown in Table 2.2.4, HHE, WLD and SH were the most common diseases in all groups at both assessments. HHE indicated lower scores in summer for all pasture groups, while especially $\mathrm{G} 1$ showed significant lower HHE scores than the other groups $(P<0.05)$. However, G4 showed an inverse relationship with HHE scores being lower in winter, compared to the groups with pasture access $(P<0.05)$. WLD scores were lower in $G 1$ and $G 3$ than in G4 in summer months $(P<0.05)$. In winter WLD scores showed no differences between the groups $(P>0.05)$. There were slightly differences of $\mathrm{SH}$ scores between the groups, whereby $\mathrm{G} 2 \mathrm{got}$ the lowest scores in summer and the highest in winter. In summer G1 and G3 showed lowest $P D$ and DD scores, compared to $G 4(P<0.05)$. No differences were found between the groups in winter $(P>0.05)$, but for all pasture groups, $P D$ and $D D$ scores were lower in summer than in winter. DID, SU and TU scores indicated no differences between groups in summer and winter. Scores of RSG were highest in G3 compared to G1 and G4 during the pasture season and compared to $G 2$ and $G 4$ in winter $(P<0.05)$. G4 showed the highest DS scores, compared to $\mathrm{G} 1$ and $\mathrm{G} 3$ in summer and $\mathrm{G} 2$ in winter $(P<0.05)$. For the scores of $\mathrm{IH}$, no significant differences were found between the groups in summer months, while in winter $G 1$ and $G 2$ with more than six hours of pasture access, lower scores than in G3 and G4 were observed. 
Table 2.2.4 Mean cumulative score at the end of the pasture (summer) and barn season (winter) of dairy farms with $>10$ hours (G1), 6 to 10 hours (G2), <6 hours of pasture access/day (G3) or without pasture access (G4), for 12 animals per farm/ farm visit, individual Scores were calculated with $Y=\alpha^{*} 1+\beta^{*} 2+\gamma^{*} 3(\text { LS Means } \pm S E)^{2}$

\begin{tabular}{|c|c|c|c|c|c|}
\hline Disease $^{1}$ & Farm visit & G1 (N=5) & $\mathrm{G} 2(\mathrm{~N}=5)$ & G3 $(\mathrm{N}=5)$ & G4 (N=5) \\
\hline \multirow{2}{*}{ HHE } & Summer & $2.23^{a} \pm 0.40$ & $4.46^{b} \pm 0.47$ & $4.08^{b} \pm 0.57$ & $5.85^{b} \pm 0.47$ \\
\hline & Winter & $5.12^{a} \pm 0.66$ & $5.07^{a} \pm 0.39$ & $5.20^{a} \pm 0.43$ & $2.37^{b} \pm 0.34$ \\
\hline \multirow{2}{*}{ WLD } & Summer & $1.20^{a} \pm 0.28$ & $2.47^{b c} \pm 0.42$ & $1.40 \mathrm{ab} \pm 0.25$ & $2.17^{c} \pm 0.23$ \\
\hline & Winter & $2.07 \pm 0.31$ & $2.27 \pm 0.34$ & $3.20 \pm 0.33$ & $2.86 \pm 0.33$ \\
\hline \multirow{2}{*}{$\mathrm{SH}$} & Summer & $1.67^{a b} \pm 0.27$ & $0.81^{a} \pm 0.19$ & $1.65^{\mathrm{ab}} \pm 0.27$ & $2.17^{b} \pm 0.33$ \\
\hline & Winter & $1.57^{\mathrm{ab}} \pm 0.32$ & $2.03^{a} \pm 0.27$ & $1.32^{b} \pm 0.44$ & $1.86^{a b} \pm 0.29$ \\
\hline \multirow{2}{*}{ PD } & Summer & $0.72^{a} \pm 0.15$ & $0.98^{a b} \pm 0.18$ & $0.75^{a} \pm 0.18$ & $1.42^{b} \pm 0.21$ \\
\hline & Winter & $1.21 \pm 0.22$ & $1.03 \pm 0.27$ & $1.39 \pm 0.27$ & $0.98 \pm 0.21$ \\
\hline \multirow{2}{*}{ DD } & Summer & $0.60^{a} \pm 0.14$ & $0.88^{\mathrm{ab}} \pm 0.16$ & $0.58^{a} \pm 0.20$ & $1.70^{b} \pm 0.28$ \\
\hline & Winter & $0.90 \pm 0.15$ & $1.25 \pm 0.26$ & $0.90 \pm 0.17$ & $2.07 \pm 0.32$ \\
\hline \multirow{2}{*}{ DID } & Summer & $0.40 \pm 0.10$ & $0.44 \pm 0.11$ & $0.82 \pm 0.19$ & $0.82 \pm 0.17$ \\
\hline & Winter & $0.64 \pm 0.15$ & $0.38 \pm 0.09$ & $0.86 \pm 0.17$ & $0.64 \pm 0.12$ \\
\hline \multirow{2}{*}{ RSG } & Summer & $0.00^{a} \pm 0.00$ & $0.22^{b c} \pm 0.10$ & $0.68^{b} \pm 0.20$ & $0.13^{\mathrm{ac}} \pm 0.07$ \\
\hline & Winter & $0.35^{\mathrm{ab}} \pm 0.16$ & $0.17^{a} \pm 0.08$ & $0.53^{b} \pm 0.15$ & $0.05^{a} \pm 0.04$ \\
\hline \multirow{2}{*}{ SU } & Summer & $0.17 \pm 0.09$ & $0.15 \pm 0.08$ & $0.23 \pm 0.10$ & $0.23 \pm 0.1$ \\
\hline & Winter & $0.13 \pm 0.05$ & $0.05 \pm 0.05$ & $0.10 \pm 0.05$ & $0.07 \pm 0.05$ \\
\hline \multirow{2}{*}{ TU } & Summer & $0.10 \pm 0.07$ & $0.10 \pm 0.10$ & $0.00 \pm 0.00$ & $0.12 \pm 0.08$ \\
\hline & Winter & $0.01 \pm 0.01$ & $0.00 \pm 0.00$ & $0.02 \pm 0.02$ & $0.12 \pm 0.07$ \\
\hline \multirow{2}{*}{ DS } & Summer & $0.05^{a} \pm 0.04$ & $0.17 \mathrm{ab} \pm 0.08$ & $0.00 a \pm 0.00$ & $0.15^{b} \pm 0.06$ \\
\hline & Winter & $0.14^{\mathrm{ab}} \pm 0.06$ & $0.08^{a} \pm 0.06$ & $0.14^{\mathrm{ab}} \pm 0.07$ & $0.29^{b} \pm 0.09$ \\
\hline \multirow{2}{*}{$\mathrm{IH}$} & Summer & $0.15 \pm 0.09$ & $0.10 \pm 0.05$ & $0.27 \pm 0.11$ & $0.40 \pm 0.13$ \\
\hline & Winter & $0.05^{a} \pm 0.03$ & $0.08^{a} \pm 0.07$ & $0.31^{b} \pm 0.12$ & $0.54^{b} \pm 0.15$ \\
\hline
\end{tabular}

${ }^{1}$ Heel Horn Erosion (HHE), White Line Disease (WLD), Sole Hemorrhage (SH), Punctual Discoloration (PD), Dermatitis digitalis (DD), Dermatitis interdigitalis (DID), Rusterholz Sole Ulcer (RSU), Sole Ulcer (SU), Toe Ulcer (TU), Double Sole (DS), Interdigital Hyperplasia (IH).

${ }^{2} \alpha=$ mild affected claws, $\beta=$ moderate affected claws, $\gamma=$ severe affected claws.

a,b Values within a row with different superscripts differ significantly at $P<0.05$. 
Table 2.2.5 Spearman correlations of claw hardness, length, scores of the most frequent diseases (results with $\mathrm{P}>0.05$ are not shown)

\begin{tabular}{|c|c|c|c|c|c|c|c|c|c|c|c|c|}
\hline & $\begin{array}{l}- \\
\Phi \\
0 \\
0 \\
\infty \\
\mathscr{D} \\
\Phi \\
\frac{c}{0} \\
\frac{0}{0} \\
\frac{0}{I}\end{array}$ & $\begin{array}{l}\overline{-} \\
\overline{\bar{N}} \\
3 \\
\infty \\
\mathscr{D} \\
\Phi \\
\frac{C}{0} \\
\frac{0}{\mathbb{N}} \\
\text { I }\end{array}$ & 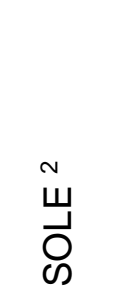 & $\stackrel{9}{3}$ & $\frac{T}{\omega}$ & Q & ํำ & $\stackrel{0}{\overline{0}}$ & $\begin{array}{l}\text { 岌 } \\
\text { 至 }\end{array}$ & I & 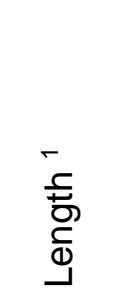 & 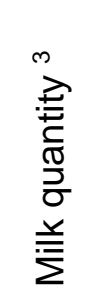 \\
\hline $\begin{array}{l}\text { Hardness } \\
\text { sole }^{1}\end{array}$ & & 0.43 & -0.11 & -0.26 & -0.13 & & & -0.10 & -0.20 & -0.10 & & 0.12 \\
\hline $\begin{array}{l}\text { Hardness } \\
\text { wall }^{1}\end{array}$ & & & -0.16 & -0.11 & 0.10 & -0.11 & & & -0.15 & -0.10 & 0.23 & \\
\hline SOLE $^{2}$ & & & & & 0.11 & 0.09 & & & 0.10 & 0.17 & & 0.13 \\
\hline WLD & & & & & 0.11 & 0.11 & 0.09 & 0.11 & 0.32 & & -0.09 & \\
\hline \multicolumn{13}{|l|}{$\mathrm{SH}$} \\
\hline PD & & & & & & & 0.13 & & 0.18 & 0.12 & & 0.12 \\
\hline DD & & & & & & & & & 0.18 & 0.16 & & \\
\hline DID & & & & & & & & & 0.19 & 0.17 & & \\
\hline $\mathrm{HHE}$ & & & & & & & & & & 0.18 & & \\
\hline $\mathrm{IH}$ & & & & & & & & & & & 0.19 & \\
\hline
\end{tabular}

${ }^{1}$ Average of both hind claws.

${ }^{2}$ SOLE $=$ Sole Ulcer (SU) + Rusterholz Sole Ulcer (RSU) + Toe Ulcer (TU), White Line Disease (WLD), Sole Hemorrhage (SH), Punctual Discoloration (PD), Dermatitis digitalis (DD), Dermatitis interdigitalis (DID), Heel Horn Erosion (HHE), Interdigital Hyperplasia (IH).

${ }^{3}$ Averaged milk quantity of 305 days.

Table 2.2.5 shows correlations of claw health and conformation parameters. The hardness of sole and wall were found to correlate with several claw diseases. High values of hardness lead to lower scores (=prevalence * severity level) of SOLE, WLD, HHE and IH. A higher sole hardness showed a negative correlation with DID and SH. A higher wall hardness showed a negative correlation with PD. Cows with long claws were found to have harder wall horn. Length influenced also the disease WLD, where the scores decreased with greater claw length and $\mathrm{IH}$, where the scores increased with greater length. When scores of SOLE and WLD were 
high, several other assessed diseases (SH, PD, DD, DID, HHE, IH) got high scores likewise. Milk quantity was slightly positive correlated with sole horn hardness and SOLE and PD scores.

\section{Discussion}

ALGERS et al. (2009) associated a higher prevalence of hoof disorders during the barn period with more time standing in manure and on concrete as well as a higher concentrate proportion in the diet. MüLLING and GrEeNOUGH (2006) emphasised the importance of claws as very sensitive interfaces between the animal and its environment. Walking and standing for a long time on concrete or hard floor leads to damage of tissue and musculoskeletal disorders, so that the authors recommend no permanent housing of dairy cows on hard flooring material.

\section{Claw length and hardness}

TOUSSAINT-RAVEN (1989) and HEILKENBRINKER et al. (2004) recommended a dorsal wall length of $7.50 \mathrm{~cm}$ for healthy dairy cows below the sixth lactation. By contrast, ARCHER et al. (2015) recommended that the minimum claw length for adult Holstein-Friesian cows should be at least $9.00 \mathrm{~cm}$. For younger cows of first and second lactation, they suggest $8.50 \mathrm{~cm}$ as an appropriate length. Values measured in the present study $(7.54$ to $8.58 \mathrm{~cm})$ ranged in-between these two recommendations.

Interactions between groups and seasons displayed that there was no consistent effect of pasturing in terms of sole and wall hardness. Nevertheless, variations between winter and summer were lowest for G4. BORDERAS et al. (2004) demonstrated that cows tend to have more severe claw lesions the softer the claws are. In agreement, WELLS et al. (1995) showed a relationship of wet claws and higher risks of claw diseases caused by an altered horn resistance. This supports findings of the present study that indicated negative correlations between several claw diseases and claw hardness. BORDERAS et al. (2004) recommended environmental conditions for dairy cows, in which the claws remain as dry as possible. An appropriately managed pasture could provide such an environment. Nevertheless, the authors pointed out that it is still questionable whether soft claws are the cause of claw diseases or the consequence. BERGSTEN et al. (2016) also proposed that positive effects of grazing in summer have to be substantiated by a well-managed housing period in winter. As the main determining factors for a well-managed housing abrasiveness of walking areas, animal activity, claw hygiene and regular claw trimming together with a minimal contact of claws with urine and faeces have to be considered. 


\section{Prevalence and severity levels of claw diseases}

The most frequently recorded diseases in all groups were HHE, WLD and SH. Even though comparisons between pasture and whole-year indoor housing are rare, BURGSTALLER et al. (2016) observed comparably high prevalences in free stall barns without pasture access. Comparing compost bedded to free stall barns, the authors observed significantly lower prevalences of WLD (20.4\% vs $46.6 \%)$, HHE (26.9\% vs $59.9 \%)$, the chronic form of SH $(6.5 \%$ vs $15.9 \%)$ and $\mathrm{IH}(0.2 \%$ vs $3.1 \%)$ in compost bedded barns, which are characterized by conditions, such as a softer and drier ground, similar to those of pastures.

A comparison of claw disease prevalence and severity for young dairy cattle with and without pasture access was conducted by LÓPEZ and PAMELA (2014). Overall, a higher prevalence of claw disorders was recorded in herds without, than in herds with pasture access. Herds with pasture access had lower prevalences of DD (17.3\%), interdigital dermatitis/ heel horn erosion (37.9\%) and $\mathrm{SH}(27.7 \%)$ than herds without pasture access $(23.8 \%, 59.5 \%$ and $33.0 \%$, respectively). Other diseases such as SU, WLD, IH and TU were observed at very low rates $(<4 \%)$. Especially the very low prevalence of WLD, when compared to the present study, can be mainly explained by the young age of animals observed. The authors stated that a health preventive management should consider access to pasture during summer season.

RODRIGUEZ-LAINZ et al. (1999) and HOLZHAUER et al. (2006, 2012) found a preventive effect of pasture access on DD. Likewise, WELLS et al. (1999) surveyed 4516 dairy farms and found the winter months without access to pasture as a significant risk factor for a high prevalence of DD. This well agrees with that fact, that $G 1$ and $G 2$ in the present study showed an increasing severity of DD in winter. LAVEN and LAWRENCE (2006) described a correlation between dirty and humid environment for the claw and an increasing DD prevalence, which was explained by the increased bacteria load of the manure. Additionally, they assumed that due to increasing prevalences of DD in the last years, lesions of DD persist longer during the pasture period. Following, it can be assumed that the DD lesions in the pasture groups of the present study remained as mild or non-active stages during the pasture season and became severe again in winter. It remains questionable whether the decreasing severity of DD for G1 and $\mathrm{G} 2$ in summer was a reaction to the soft and dry pasture ground or the increasing severity in winter was caused by poorly equipped and managed barns.

SOMERS et al. (2003) examined Dutch dairy farms with different flooring systems with pasture and a zero-grazing feeding system. Hind legs were examined for the presence and severity of claw diseases during hoof trimming events at the end of the pasture and barn period. For $\mathrm{SH}$, the prevalence of severe cases was twice as high for cows on slatted floor without, compared to those with pasture access. In contrast, the present as well as the study of HOLZHAUER et al. 
(2012) showed that cows without access to pasture did not have a higher prevalence of SH than cows with access to pasture.

Prevalence of severe and moderate severity levels of RSG were notably higher in G3 than in the other groups. In general, an increase of sole ulcers is indicated when pathways from barn to pasture are in a poor condition. Most of the pathways of the examined farms were concreted or paved, though conditions of pasture tracks were not assessed in this study. They are, however, warranted to be evaluated in further studies as possible explaining factor. As another determining factor, BERGSTEN et al. (2015) associated a higher prevalence of sole ulcers with a high pasture stocking density. Stocking density on the pasture was not evaluated in this study. However, farms in G3 with limited pasture duration had the least consolidated pasture areas and consequently highest stocking density compared with G1 and G2. This high stocking density may be one explanation for the increased prevalence of severe and moderate RSG in G3.

\section{Correlations between claw diseases}

Several claw diseases indicated to be predisposing for other ones. In agreement, AMORY et al. (2008), HOLZHAUER et al. (2008) and SANDERS et al. (2009) stated certain positive correlations between SH and other claw disorders (SU, WLD, DD, TU). Correlations of SH with SU and WLD can be supported by findings of this study. Furthermore, HOLZHAUER et al. (2006), as well as the present study, showed positive correlations of HHE, IH occurrence and incidences of DD. KOENIG et al. (2005) indicated a high milk yield after calving to be associated with a greater risk for claw and foot disorders in the same lactation. Their results $(0.08)$ and the results of the present study (0.13) showed positive correlations between a high milk yield and SU. In contrast to the present study, O'DRISCOLL et al. (2008) found no correlation between hardness and dermatitis scores $(P>0.1)$ and low Pearson correlations with sole lesion scores $(-0.226$; $P<0.01)$ and heel erosion scores $(-0.075 ; P<0.05)$. As the major influencing factors for dermatitis and heel horn erosion the authors mentioned claw contact with excessive amounts of moisture and manure.

\section{Effect of access to pasture on lameness}

BARKER et al. (2010) assessed lameness of dairy cows being housed indoors or on pasture for different periods. Cows that were never housed showed the lowest lameness prevalence $(20 \%)$. The other farms were clustered by the number of housed days into 0-60 days, 61120 days, $121-180$ days and $>180$ days and showed mean lameness prevalences of $28 \%$, $40 \%, 40 \%$ and $47 \%$, respectively. Cows with year-round indoor housing were recorded with a mean lameness prevalence of $42 \%$. HASKELL et al. (2006) found also more lame cows on farms without (39\%) than on farms with pasture access (15\%). WESTIN et al. (2016) found the barn season as a risk factor for lameness of dairy cows because of inappropriate barn 
equipment, like a narrow feed alley, a not fitting average barn width and an obstructed lunge space. These results indicated that a year-round indoor housing has a negative effect on foot and leg health and that especially inappropriate cubicle and barn dimensions can increase lameness and leg lesions for large and heavy cows.

\section{Conclusion}

Pasturing showed positive effects of decreasing prevalences of HHE and WLD during the summer season. Additionally, groups with pasture access were recorded with lower prevalences of PD and DD both in summer and winter, compared to the group without pasture access. Groups with more than six hours pasture access indicated a decreasing severity of DD during the pasture season. In the group without pasture access approximately $50 \%$ of the DD affected claws were scored as severe compared to the other groups with maximum $25 \%$ of severe DD affected claws. Thus, independent of its intensity, pasture access showed positive effects especially for claw diseases related to moist environments. But, appropriate barn interior, i.e. cubicle design, claw trimming intervals and good barn management during the winter months appear to be more important for claw health of dairy cows than pasturing.

\section{Acknowledgements}

The study was supported by the Ministry for Science and Culture of Lower Saxony (MWK) within the collaborative research project SAM, Analysis of Dairy Production: Grazing versus Indoor Housing of Dairy Cows, Support Code: ZN 2864. Furthermore, the authors would like to acknowledge Dr. Hans-Peter Klindworth for his support during data collection and indeed the farmers who took part in the study.

\section{References}

Algers, B., G. Bertoni, D. Broom, J. Hartung, L. Lidfors, J. Metz, L. Munksgaard, T.N. Pina, P. Oltenacu, J. Rehage and J. Rushen (2009): Scientific report on the effects of farming systems on dairy cow welfare and disease. Report of the Panel on Animal Health and Welfare. Annex to the EFSA Journal (2009) 1143, 1-284.

Amory, J.R., Z.E. Barker, J.L. Wright, S.A. Mason, R.W. Blowey and L.E. Green (2008): Associations between sole ulcer, white line disease and digital dermatitis and the milk yield of 1824 dairy cows on 30 dairy cow farms in England and Wales from February 2003-November 2004. Preventive Veterinary Medicine 83, 381-391.

Archer, S.C., N.J. Bell and J.H. Huxley (2010): Lameness in UK dairy cows: a review of the current status. In Practice 32, 492-504. 
Archer, S.C., R. Newsome, H. Dibble, C.J. Sturrock, M.G.G. Chagunda, C.S. Mason and J.N. Huxley (2015): Claw length recommendations for dairy cow foot trimming. Veterinary Record 177, 222.

Barker, Z.E., K.A. Leach, H.R. Whay, N.J. Bell and D.C.J. Main (2010): Assessment of lameness prevalence and associated risk factors in dairy herds in England and Wales. Journal of Dairy Science 93, 932-941.

Bergsten, C., E. Telezhenko and M. Ventorp (2016): Influence of soft or hard floors before and after first calving on dairy heifers locomotion, claw and leg health. Animals 5, 662-668.

Borderas, T.F., B. Pawluczuk, A.M. De Passillé and J. Rushen (2004): Claw Hardness of Dairy Cows: Relationship to Water Content and Claw Lesions. Journal of Dairy Science 87, 2085-2093.

Burgstaller, J., J. Raith, S. Kuchling, V. Mandl, A. Hund and J. Kofler (2016): Claw health and prevalence of lameness in cows from compost bedded and cubicle freestall dairy barns in Austria. The Veterinary Journal 216, 81-86.

Chapinal, N., A.K. Barrientos, M.A. Von Keyserlingk, E. Galo and D.M. Weary (2013): Herdlevel risk factors for lameness in freestall farms in the north-eastern United States and California. Journal of Dairy Science 96, 318-328.

Corazzin, M., E. Piasentier, S. Dovier and S. Bovolenta (2010): Effect of summer grazing on welfare of dairy cows reared in mountain tie-stall barns. Italian Journal of Animal Science 9, 304-312.

Dippel, S., M. Dolezal, C. Brenninkmeyer, J. Brinkmann, S. March, U. Knierim and C. Winckler (2009): Risk factors for lameness in freestall-housed dairy cows across two breeds, farming systems, and countries. Journal of Dairy Science 92, 5476-5486.

Eilers, T.G. (2008): Langzeitbeobachtungen zur Klauengesundheit in vier Milchviehbetrieben im nordwestlichen Niedersachsen unter Berücksichtigung ausgewählter Risikoindikatoren auf Einzeltier- und Herdenebene. http://www.diss.fuberlin.de/diss/servlets/MCRFileNodeServlet/FUDISS_derivate_000000005274/Eilers.p df. Accessed January 15, 2017.

Gabarino, E.J., J.A. Hernandez, J.K. Shearer, C.A. Risco and W.W. Thatcher (2004): Effect of lameness on ovarian activity in postpartum Holstein cows. Journal of Dairy Science 87, 4123-4131.

Haskell, M.J., L.J. Rennie, V.A. Bowell, M.J. Bell and A.B. Lawrence (2006): Housing system, milk production, and zero-grazing effects on lameness and leg injury in dairy cows. Journal of Dairy Science 89, 4259-4266.

Heilkenbrinker, T., D. Landmann and H.P. Klindworth (2004): Funktionelle Klauenpflege. Ed. Chamber of Agriculture Hannover, Germany. 
Hernandez, J., J.K. Shearer and D.W. Webb (2001): Effect of lameness on the calving-toconception interval in dairy cows. Journal of the American Veterinary Medical Association 218, 1611-1614.

Hernandez-Mendo, O., M.A. Von Keyserlingk, D.M. Veira and D.M. Weary (2007): Effects of pasture on lameness in dairy cows. Journal of Dairy Science 90, 1209-1214.

Holzhauer, M., C. Hardenberg, C.J.M. Bartels and K. Frankena (2006): Herd- and cow-level prevalence of digital dermatitis in the Netherlands and associated risk factors. Journal of Dairy Science 89, 580-588.

Holzhauer, M., C. Hardenberg and C.J.M. Bartels (2008): Herd and cow-level prevalence of sole ulcers in The Netherlands and associated-risk factors. Preventive Veterinary Medicine 85, 125-135.

Holzhauer, M., B. Brummelman, K. Frankena and T.J.G.M Lam (2012): A longitudinal study into the effect of grazing on claw disorders in female calves and young dairy cows. The Veterinary Journal 193, 633-638.

Huxley, J.N. (2013): Impact of lameness and claw lesions in cows on health and production. Livestock Science 156, 64-70.

Ito, K., M.A. Von Keyserlingk, S.J. Leblanc and D.M. Weary (2010): Lying behaviour as an indicator of lameness in dairy cows. Journal of Dairy Science 93, 3553-3560.

Kanswohl, N. and P. Sanftleben (2006): Analyse und Bewertung von Hoch- und Tiefboxen für Milchrinder aus arbeitswirtschaftlicher, ethologischer, hygienischer und ökonomischer Sicht. http://www.landwirtschaftmv.de/cms2/LFA_prod/LFA/content/de/Fachinformationen/Tierproduktion/Milcherzeugu ng/FoBericht_HochTierfboxen/FB_Hoch_Tiefboxen_Kanswohl.pdf. Accessed January 09, 2017.

Koenig, S., A.R. Sharifi, H. Wentrot, D. Landmann, M. Eise and H. Simianer (2005): Genetic parameters of claw and foot disorders estimated with logistic models. Journal of Dairy Science 88, 3316-3325.

Landmann, D., M. Eise, I. Emmerich, A. Fiedler, K. Mahlkow-Nerge, J. Maierl, K. Maiworm and K.E. Müller (2011): Klauengesundheit beim Rind. aid Infodienst, Verbraucherschutz, Ernährung, Landwirtschaft e.V. 1541/2011, 52-53.

Laven, R.A. and K.R. Lawrence (2006): An evaluation of the seasonality of veterinary treatments for lameness in UK dairy cattle. Journal of Dairy Science, 89, 3858-3865.

López, M. and E. Pamela (2014): Effect of grazing, calving and disease history on severity of claw lesions in Dutch young dairy cattle. http://repositorio.educacionsuperior.gob.ec/bitstream/28000/1457/1/T-SENESCYT00590.pdf. Accessed January 08, 2017. 
Mülling, C.H. and P.R. Greenough (2006): Applied Physiopathology of the Foot. http://www.ivis.org/proceedings/wbc/wbc2006/mulling.pdf?LA=1. Accessed January 23, 2017.

O'Driscoll, K., L. Boyle, P. French and A. Hanlon (2008): The effect of out-wintering pad design on hoof health and locomotion score of dairy cows. Journal of Dairy Science 91, 544553.

Rodriguez-Lainz, A., P. Melendez-Retamal, D.W. Hird, D.H. Read and R.L. Walker (1999): Farm- and host-level risk factors for papillomatous digital dermatitis in Chilean dairy cattle. Preventive Veterinary Medicine 42, 87-97.

Rushen, J., E. Pombourcq and A.M. De Passillé (2007): Validation of two measures of lameness in dairy cows. Applied Animal Behaviour Science 106, 173-177.

Sanders, A.H., J.K. Shearer and A. De Vries (2009): Seasonal incidence of lameness and risk factors associated with thin soles, white line disease, ulcers, and sole punctures in dairy cattle. Journal of Dairy Science 92, 3165-3174.

Sogstad, A.M., T. Fjeldaas and O. Østerås (2005): Lameness and claw lesions of the Norwegian red dairy cattle housed in free stalls in relation to environment, parity and stage of lactation. Acta Veterinaria Scandinavica 46, 203-217.

Somers, J., K. Frankena, E.N. Noordhuizen-Stassen and J.H.M. Metz (2003): Prevalence of claw disorders in Dutch dairy cows exposed to several floor systems. Journal of Dairy Science 86, 2082-2093.

Telezhenko, E. and C. Bergsten (2005): Influence of floor type on the locomotion of dairy cows. Applied Animal Behaviour Science 93, 183-197.

Toussaint-Raven, E. (1989): Cattle foot care and claw trimming. Farming Press, Ipswich, UK. 14-20.

Weber, A., W. Junge, E. Stamer and G. Thaller (2012): Investigation of locomotion score in dairy cows. Proceedings of $63 \mathrm{rd}$ annual meeting of the European federation of animal science. Reading, August 27 to 30, 2012. p. 204.

Wells, S.J., A.M. Trent, W.E. Marsh, N.B. Williamson and R.A. Robinson (1995): Some risk factors associated with clinical lameness in dairy herds in Minnesota and Wisconsin. The Veterinary Record 136, 537-540.

Wells, S.J., L.P. Garber and B.A. Wagner (1999): Papillomatous digital dermatitis and associated risk factors in U.S. dairy herds. Preventive Veterinary Medicine 38, 11-24.

Westin, R., A. Vaughan, A.M. De Passillé, T.J. Devries, E.A. Pajor, D. Pellerin, J.M. Siegford, A. Witaifi, E. Vasseur and J. Rushen (2016): Cow- and farm-level risk factors for lameness on dairy farms with automated milking systems. Journal of Dairy Science 99, 3732-3743. 
Whay, H.R., A.E. Waterman, A.J.F. Webster and J.K. O'brien (1998): The influence of lesion type on the duration of hyperalgesia associated with hind limb lameness in dairy cattle. Veterinary Journal 156, 23-29.

Zähner, M., S. Schrade, W. Schaeren and J. Schmidtko (2009): Wiederkäuer: Haltung und Gesundheit: Neue Materialien als Einstreu in Liegeboxen von Milchviehställen. Proceedings of the 10th science conference organic farming. Reading, February 11 to 13, 2009. 50-53. 


\title{
2.3 Einfluss von Stall- und Weidehaltung auf ausgewählte Tiergesundheits- und Leistungsparameter von Milchkühen
}

\author{
L. Armbrecht ${ }^{1}$, C. Lambertz ${ }^{2}$, D. Albers ${ }^{3}$ und M. Gauly ${ }^{2}$ \\ ${ }^{1}$ Georg-August-Universität Göttingen, Fakultät für Agrarwissenschaften, Department \\ für Nutztierwissenschaften, Albrecht-Thaer-Weg 3, 37075 Göttingen \\ ${ }^{2}$ Freie Universität Bozen, Fakultät für Naturwissenschaften und Technik, Universitäts- \\ platz 5, 39100 Bozen, Italien \\ ${ }^{3}$ Landwirtschaftskammer Niedersachsen, Geschäftsbereich Landwirtschaft, Mars-la- \\ Tour-Str. 6, 26121 Oldenburg
}

\section{Zusammenfassung}

Ziel der vorliegenden Studie war es zu untersuchen, inwiefern sich die Weidehaltung auf den Gesundheitsstatus und die Leistung von Milchkühen auswirkt und zu bewerten, welchen Einfluss die tägliche Weidedauer hat. Des Weiteren wurde der Einfluss der Liegeboxengestaltung untersucht. Dafür wurden auf 61 Milchviehbetrieben ausgewählte Indikatoren des Welfare Quality ${ }^{\circledR}$ Protokolls untersucht, Daten der Milch-Leistungsprüfungen von 2012 bis 2015 analysiert sowie Beschaffenheit der Liegefläche und Maße der Liegeboxen erfasst. Anhand der Anzahl täglicher Weidestunden wurden die Betriebe eingeteilt in: Gruppe 1 (G1) mit > 10 Stunden Zugang zur Weide pro Tag, Gruppe 2 (G2) mit 6-10 Stunden, Gruppe 3 (G3) mit < 6 Stunden und Gruppe 4 (G4) mit ganzjähriger Stallhaltung. G1 und G2 zeigten im dreijährigen Durchschnitt ca. 1000 kg weniger Milchmenge als G3 und G4. G4 wies jedoch vergleichsweise höhere Abgangsraten und mehr Tiere mit schweren Lahmheiten auf. Mit zunehmenden Weidestunden, wurden weniger Tiere mit leichten Lahmheiten und haarlosen Stellen beobachtet. In den Sommermonaten konnte im Durchschnitt der drei Jahre ein Rückgang von Fett- und Eiweißgehalten für alle Gruppen, ein Anstieg der Zellzahlen für G2, G3 und G4 und ein Anstieg des Harnstoffgehaltes für G1 und G2 festgestellt werden. Insbesondere G1 zeigte große Schwankungen zwischen Sommer- und Wintermonaten bei Fett-, Harnstoffgehalten und dem Fett-Eiweiß-Quotienten. Mangelhafte Liegeboxen sowie schlechte Tier-Fressplatz- und Tier-Liegeboxen-Verhältnisse, zeigten zudem signifikant negative Einflüsse auf Milchleistung, Eiweiß- und Harnstoffgehalte, Abgangsraten, Integumentschäden und Lahmheiten.

\section{Einleitung}

In ganz Europa ist mittlerweile ein Rückgang der Weidehaltung (REIJS et al., 2013), überwiegend aufgrund von wachsenden Tierbeständen, zu wenig arrondiertem Grünland, 
hohen Pachtpreisen bei vergleichsweise kostengünstigem Kraftfutter sowie fehlenden Erfahrungen in Praxis und Beratung zum Weidemanagement (LEISEN, 2014) zu beobachten. In der Diskussion um Tierwohl in der Nutztierhaltung wird jedoch das Milchvieh im Vergleich zu anderen Tierhaltungssystemen gerade deshalb positiv vom Konsumenten bewertet, weil Milchviehhaltung häufig noch mit Weidezugang und dieser wiederum mit Nachhaltigkeit und Tierwohl in Verbindung gebracht wird (WEIB, 2014; WEINRICH et al., 2014). Internationale Untersuchungen zeigten bereits eine verbesserte Tiergesundheit bezüglich Mortalität, Integumentschäden (BUROW, 2012), Mastitisprävalenzen (WASHBURN et al., 2002) sowie Klauengesundheit und Lokomotion (HERNANDEZ-MENDO et al., 2007; Olmos et al., 2009), verglichen mit ganzjähriger Stallhaltung. Die Fragestellungen dieser Untersuchung waren daher, ob die Weidehaltung Effekte auf die Tiergesundheit oder Leistung mit sich bringt und in wie weit die Liegeboxen-Gestaltung, als wichtigstes Element der Stalleinrichtung, einen Einfluss hat.

\section{Material und Methoden}

\section{Betriebsauswahl}

Die Daten wurden auf 61 konventionellen Milchviehbetrieben mit Liegeboxen-Laufställen in Niedersachsen erhoben. Die Ställe waren entweder mit Hochboxen (34 Betriebe) oder Tiefboxen (27 Betriebe) ausgestattet, außerdem hatten die Tiere auf 12 Betrieben Zugang zu einem Laufhof. Es wurden nur Betriebe ausgewählt, deren Herde aus mindestens 95\% Holstein-Friesian oder Red-Holstein Kühen bestand. Die Betriebe hielten durchschnittlich 141 Kühe (SD = 82,89), mit einer Spanne von 55 bis 585 Tieren. Im Mittel produzierten die Betriebe eine Energie korrigierte Milchmenge $(E C M)$ von $9.430 \mathrm{~kg}(\mathrm{SD}=892)$. Detaillierte Daten zur Charakterisierung der Betriebe sind in Tabelle 2.3.2 abgebildet. Die 61 Betriebe wurden eingeteilt nach Anzahl der Stunden mit Zugang zur Weide, der den Tieren ermöglicht wurde: Gruppe 1 (G1) mit > 10 Stunden Zugang zur Weide pro Tag, Gruppe 2 (G2) mit 610 Stunden, Gruppe 3 (G3) mit < 6 Stunden und Gruppe 4 (G4) mit ganzjähriger Stallhaltung.

\section{Datenerfassung}

Die Datenerfassung erstreckte sich von Juli 2014 bis April 2015. Dabei wurden 32 tier-, management- und ressourcenbezogene Indikatoren, wie sie im Welfare Quality ${ }^{\circledR}$ Protokoll für Rinder (WQP; WELFARE QUALITY ${ }^{\circledR}$, 2012) beschrieben sind, bewertet. Zur genaueren Beschreibung der Datenerfassung des WQP siehe Kapitel 2.1.

Aus den offiziellen, monatlichen Milchleistungsprüfungs (MLP) - Daten der Jahre 2012 bis 2015 wurden Milchmenge (ECM), Fett- und Eiweißgehalte der Milch, Harnstoffgehalte, Zellzahlen und Fett-Eiweiß-Quotienten ausgewertet. Zusätzlich wurden aus den MLP- 
Jahresabschlüssen die Abgangsraten, die Nutzungsdauer und die Totgeburtenrate mit in die Auswertungen aufgenommen.

Daneben wurden auf jedem Betrieb jeweils zwei repräsentative Liegeboxen vermessen. Ausgewählt wurden dafür eine wandständige und eine gegenständige Liegebox, die sich nicht am äußersten Rand einer Liegeboxenreihe befanden und auch sonst keine Besonderheiten, wie z.B. verbogene Boxenbegrenzungen aufwiesen. Dabei wurden die Höhe des Nackenriegels, die Länge vom Nackenriegel bis zum Boxenende, die Höhe des Durchlaufschutzes, die Gesamtlänge und die Breite der Liegebox ausgemessen. Zusätzlich wurde das TierFressplatz-Verhältnis (TFV) und das Tier-Liegeplatz-Verhältnis (TLV) festgehalten.

\section{Beurteilung der tierbezogenen Indikatoren}

Abhängig von der absoluten Herdengröße des entsprechenden Betriebes, wurden die tierbezogenen Indikatoren anhand einer Stichprobengröße von 34 bis 82 Tieren erfasst. Die Stichprobengröße wurde nach den Vorgaben des WQP berechnet (siehe auch Kapitel 2.1). Insgesamt wurden für die vorliegende Studie 6.354 Tiere während der beiden Betriebsbesuche untersucht.

Das Vorgehen der klinischen Untersuchung der Tiere ist im Detail im WQP beschrieben. Nach dessen Vorgaben wurde jeweils nur eine Seite des Tieres untersucht. Die klinische Untersuchung umfasste Integumentschäden wie haarlose Stellen, Hautläsionen und Schwellungen sowie die Sauberkeit der Beine, des Euters und der Flanke. Es wurde außerdem eine Beurteilung der Lahmheit und des BCS an selbigen Tieren durchgeführt.

\section{Statistische Analyse}

Das folgende lineare gemischte Effekte Modell (GLIMMIX) wurde verwendet um die Indikatoren des WQP zu analysieren:

$$
Y_{i j k}=\mu+a_{i}+b_{j}+c_{i j}+d_{k}+\varepsilon_{i j k}
$$

mit $Y_{\mathrm{ijk}}=$ Ausprägung der Parameter, $\mu=$ Gesamtmittelwert der Stichprobe, $a_{i}=$ fixer Effekt der i-ten Gruppe (G1, G2, G3, G4), $b_{j}=$ fixer Effekt des Betriebsbesuchs $(1,2)$, $c_{i j}=$ Interaktion zwischen der i-ten Gruppe und dem Betriebsbesuch j, $d_{k}=$ zufälliger Effekt des Betriebs $k$ und $\varepsilon_{\mathrm{ijk}}=$ zufälliger Restfehler. Die MLP-Daten der Jahre 2012 bis 2015 wurden mit dem gleichen Modell berechnet, jedoch erweitert um den fixen Effekt der Herdengröße des jeweiligen Betriebs. Der fixe Effekt des Betriebsbesuchs wurde bei der Analyse der MLP-Daten nicht berücksichtigt. Liegeboxen-Effekte wurden ebenfalls mit diesem Modell berechnet, jedoch ohne den fixen Effet der Herdengröße oder des Betriebsbesuchs. Bis auf die Parameter Nutzungsdauer, Totgeburten- und Abgangsrate, die nur als jährliche Daten zur Verfügung standen, wurden alle anderen MLP-Parameter als monatliche Daten der Jahre 2012 bis 2015 ausgewertet. 
Alle statistischen Analysen wurden mit SAS, Version 9.3 (Statistical Analysis Systems, Cary, NC, USA) durchgeführt. Der Betrieb wurde als statistische Einheit definiert. Ergebnisse wurden bei einer Wahrscheinlichkeit von $\alpha<0.05$ als statistisch signifikant betrachtet. Unterschiede zwischen den Gruppen oder den Besuchszeitpunkten im WQP wurden mit dem Tukey-Kramer Test für asymmetrische Daten berechnet. Im Modell der MLP-Daten wurde dafür die Bonferroni-Korrektur angewendet. Alle Daten wurden vor den Analysen auf Normalverteilung geprüft. War diese nicht gegeben, wurden die Daten log-, sqrt- oder arcsin-transformiert. In den Ergebnissen sind die Werte der einzelnen Parameter als nicht-transformierte Daten dargestellt. Für Parameter, die auch nach Transformation nicht normal verteilt waren, wurde für die Berechnung der P-Werte eine Poisson- oder Negativ-binomial-Verteilung innerhalb der GLIMMIX Prozedur verwendet. Die Berechnung der Pearson-Korrelationen erfolgte mit der Prozedur PROC CORR.

Die Einteilung der Liegeboxenabmessungen in "gut" und „mangelhaft“ wurde nach folgenden Vorgaben durchgeführt: Bei weniger als 5\% Abweichung von den empfohlenen Werten der Landwirtschaftskammer Nordrhein-Westfahlen (LK NRW, 2012) wurde die Messung als "gut“ eingestuft, andernfalls als „zu kurz“. Wenn von den fünf gemessenen Parametern in der Liegebox maximal zwei „zu kurz“ waren, wurden die Liegeboxen auf diesem Betreib als "gut“ eingestuft, vorausgesetzt dies galt für beide repräsentativ ausgemessenen Boxen auf dem jeweiligen Betrieb. War eine der ausgemessenen Liegeboxen „mangelhaft“ (= mehr als zwei Messungen „zu kurz“), so wurden auf dem Betrieb alle Liegeboxen als „mangelhaft“ eingestuft. Um die Ergebnisse der Liegeboxenabmessungen zu analysieren, wurde das lineare gemischte Effekte Modell (GLIMMIX) $Y_{\mathrm{ijk}}=\mu+a_{i}+b_{j}+c_{k}+\varepsilon_{i j k}$ verwendet. Mit $Y_{i j k}=$ Ausprägung der Parameter, $\mu=$ Gesamtmittelwert der Stichprobe, $a_{i}=$ fixer Effekt der i-ten Liegeboxenabmessung (1="gut", 6="mangelhaft"), b $\mathrm{C}_{\mathrm{k}}=$ zufälliger Effekt des Betriebs $\mathrm{k}$ und $\varepsilon_{\mathrm{ijk}}=$ zufälliger Restfehler.

\section{Ergebnisse}

\section{Gruppenunterschiede von Leistungs- und Gesundheitsparametern}

Im Vergleich zu den Gruppen G1 und G2 mit den meisten Weidestunden, hatten Betriebe in den Gruppen G3 und G4 größere Herden ( $P<0.05$, Tabelle 2.3.2). Während $G 1$ und $G 2$ im Durchschnitt der drei untersuchten Jahre eine Leistung von etwa $8.950 \mathrm{~kg}$ ECM pro Tier und Jahr aufwiesen, lag sie in G3 und G4 etwa 1.000 kg höher. Die Eiweiß- und Fettgehalte, Harnstoffwerte sowie die Zellzahl unterschieden sich nur geringfügig zwischen den vier Gruppen $(P>0,05)$. Der Anteil der Herde mit einem Fett-Eiweiß-Quotienten $(F E Q)<1$, war in G1 und G4 höher als in G2 und G3 $(P<0,05)$, während für den Parameter FEQ $>1,5$ keine Unterschiede zwischen den Gruppen festgestellt wurden ( $P>0,05)$. G2 zeigte die geringsten Abgangsraten im Vergleich zu den anderen Gruppen $(P<0,05)$. Bei der Nutzungsdauer 
wiederum zeigte $G 2$ den signifikant höchsten Wert $(P<0,05)$, verglichen mit den anderen drei Gruppen, die sich untereinander nicht unterschieden $(P>0,05)$. Über alle Gruppen hinweg, war der Anteil an Tiefboxen geringer als der der Hochboxen, wobei in G1 die meisten Betriebe mit Hochboxen und in G4 die meisten Betriebe mit Tiefboxen festgestellt wurden. G1 zeigte die meisten Hektar arrondierter Grünlandfläche, welche in G4 am geringsten war. Die Anzahl der Weidetage pro Jahr war in G1 am höchsten und in G3 am geringsten. Die prozentuale Anzahl an weidenden Tieren war in allen Weidegruppen nahezu gleich $(P>0,05)$. Das TLV sowie das TFV zeigten keine signifikanten Unterschiede zwischen den vier Gruppen $(P>0,05)$. Die Aufteilung der Abkalbungen nach Quartal wies in keiner der Gruppen auf eine saisonale Abkalbung hin (Tabelle 2.3.1).

Tabelle 2.3.1 Saisonale Verteilung (in \%) der Abkalbungen in 61 Milchviehbetrieben mit > 10 Stunden (G1), 6 bis 10 Stunden (G2), < 6 Stunden Weidegang/ Tag (G3) oder ohne Weidezugang (G4) (LS Means und SE)

\begin{tabular}{c|cccccccc}
\hline & \multicolumn{2}{|c}{ Quartal 1 } & \multicolumn{2}{c}{ Quartal 2 } & \multicolumn{2}{c}{ Quartal 3 } & \multicolumn{2}{c}{ Quartal 4 } \\
\cline { 2 - 9 } & $(\%)$ & SE & $(\%)$ & SE & $(\%)$ & SE & $(\%)$ & SE \\
\hline G1 & 28,44 & 1,32 & 25,81 & 1,16 & 22,27 & 1,14 & 23,48 & 1,29 \\
G2 & 27,99 & 1,26 & 25,70 & 1,11 & 20,54 & 1,09 & 25,78 & 1,23 \\
G3 & 25,45 & 1,29 & 24,78 & 1,13 & 23,80 & 1,11 & 25,96 & 1,26 \\
G4 & 26,77 & 1,21 & 24,00 & 1,06 & 22,38 & 1,04 & 26,85 & 1,18 \\
\hline
\end{tabular}

Betrachtet man die Abgangsgründe im Einzelnen (Tabelle 2.3.3), sind über alle vier Gruppen in den Jahren 2012 bis 2015 als häufigste Abgangsgründe Unfruchtbarkeit (23,9\%), Klauenerkrankungen (14,7\%), Mastitis Erkrankungen (14,5\%) und die Zuchtuntauglichkeit $(9,4 \%)$ angegeben. Die einzelnen Abgangsgründe zeigen für Alter, Zucht, Leistung, Unfruchtbarkeit und Melkbarkeit keine signifikanten Unterschiede zwischen den Gruppen $(P>0,05)$. Den Abgangsgrund Mastitis Erkrankungen gab G4 am häufigsten an, verglichen mit $G 1$ und $G 2(P<0,05)$. Klauenerkrankungen waren in $G 2$ häufiger als Abgangsursache angegeben als in $G 3(P<0,05)$, jedoch nur geringfügig häufiger als in $G 1$ und $G 4(P>0,05)$. Als Abgangsgrund wurden Stoffwechselerkrankungen in G4 häufiger angegeben als in $G 2$ $(P<0,05)$, gegenüber $G 1$ und $G 3$ gab es keine signifikanten Unterschiede $(P>0,05)$. Sonstige Erkrankungen wurden in G1 und G2 häufiger als Abgangsgrund angegeben als in G3 $(P<0,05)$, für $G 4$ zeigten sich hier keine signifikanten Unterschiede zu den anderen Gruppen. 
Die Ergebnisse der Parameter zur Tiergesundheit, bezogen auf das WQP, sind in Kapitel 2.1 dieser Arbeit abgebildet.

Tabelle 2.3.2 Betriebscharakteristika im Durchschnitt der Jahre 2012-2015 von 61 Milchviehbetrieben mit > 10 Stunden (G1), 6 bis 10 Stunden (G2), < 6 Stunden Weidegang/ Tag (G3) oder ohne Weidezugang (G4) (LS Means \pm SE)

\begin{tabular}{|c|c|c|c|c|}
\hline $\begin{array}{c}\text { Betriebs- } \\
\text { charakteristika }\end{array}$ & $\begin{array}{c}\text { Gruppe } 1 \\
N=15\end{array}$ & $\begin{array}{c}\text { Gruppe } 2 \\
\mathrm{~N}=15\end{array}$ & $\begin{array}{c}\text { Gruppe } 3 \\
N=15\end{array}$ & $\begin{array}{c}\text { Gruppe } 4 \\
N=16\end{array}$ \\
\hline Herdengröße & $100^{\mathrm{a}}( \pm 3,74)$ & $108^{a}( \pm 3,51)$ & $121^{b}( \pm 3,62)$ & $173^{c}( \pm 3,36)$ \\
\hline $\mathrm{ECM}(\mathrm{kg})$ & $8.950^{a}( \pm 127)$ & $8.987^{a}( \pm 118)$ & $9.740^{b}( \pm 121)$ & $9.832^{b}( \pm 161)$ \\
\hline Eiweiß (\%) & $3,41( \pm 0,01)$ & $3,35( \pm 0,01)$ & $3,41( \pm 0,01)$ & $3,38( \pm 0,01)$ \\
\hline Fett $(\%)$ & $4,03( \pm 0,02)$ & $4,07( \pm 0,01)$ & $4,10( \pm 0,01)$ & $3,98( \pm 0,01)$ \\
\hline Harnstoff (ppm) & $248( \pm 2,74)$ & $250( \pm 2,74)$ & $246( \pm 2,76)$ & $234( \pm 2,58)$ \\
\hline $\begin{array}{l}\text { Zellzahl } \\
\text { (TSD/ ml) }\end{array}$ & $231( \pm 6,05)$ & $214( \pm 5,48)$ & $241( \pm 6,09)$ & $217( \pm 5,70)$ \\
\hline $\begin{array}{l}\text { FEQ }<1 \\
\text { (\% d. Herde) }\end{array}$ & $12,31^{\mathrm{a}}( \pm 0,52)$ & $7,98^{b}( \pm 0,47)$ & $8,25^{b}( \pm 0,52)$ & $12,66^{a}( \pm 0,50)$ \\
\hline $\begin{array}{l}\text { FEQ }>1,5 \\
(\% \text { d. Herde) }\end{array}$ & $4,25( \pm 0,21)$ & $5,43( \pm 0,20)$ & $4,96( \pm 0,20)$ & $4,82( \pm 0,20)$ \\
\hline $\begin{array}{l}\text { Abgangsrate } \\
(\%)\end{array}$ & $25,72^{a}( \pm 1.24)$ & $21,74^{b}( \pm 1,55)$ & $25,70^{\mathrm{a}}( \pm 1.20)$ & $26,61^{\text {a }}( \pm 1,12)$ \\
\hline $\begin{array}{l}\text { Nutzungsdauer } \\
\text { (Monate) }\end{array}$ & $41,54^{a}( \pm 0,56)$ & $44,34^{b}( \pm 0,51)$ & $41,18^{a}( \pm 0,56)$ & $40,91^{\text {a }}( \pm 0,53)$ \\
\hline $\begin{array}{l}\text { Betriebe mit } \\
\text { Tiefboxen }\end{array}$ & 4 & 6 & 6 & 11 \\
\hline $\begin{array}{l}\text { Betriebe mit } \\
\text { Hochboxen }\end{array}$ & 11 & 9 & 9 & 5 \\
\hline $\begin{array}{l}\text { Arrondierte } \\
\text { Grünlandflächen }\end{array}$ & $54,63 \pm 6,75$ & $39,27 \pm 6,75$ & $37,61 \pm 6,98$ & $16,68 \pm 6,53$ \\
\hline Weidetage/ Jahr & $195 \pm 6,81$ & $179 \pm 6,11$ & $161 \pm 6,77$ & 0 \\
\hline $\begin{array}{l}\text { weidende Tiere } \\
\text { (\% d. Herde) }\end{array}$ & $93 \pm 2,87$ & $95 \pm 2,87$ & $95 \pm 2,97$ & 0 \\
\hline
\end{tabular}

a,b,c Werte innerhalb einer Reihe mit verschiedenen Beschriftungen unterscheiden sich signifikant mit $P<0,05$. 
Tabelle 2.3.3 Abgangsgründe (in \%) im Durchschnitt der Jahre 2012-2015 von 61 Milchviehbetrieben mit > 10 Stunden (G1), 6 bis 10 Stunden (G2), < 6 Stunden Weidegang/ Tag (G3) oder ohne Weidezugang (G4) (LS Means \pm SE)

\begin{tabular}{|c|c|c|c|c|}
\hline Abgangsgründe & $\begin{array}{c}\text { Gruppe } 1 \\
\mathrm{~N}=15\end{array}$ & $\begin{array}{c}\text { Gruppe } 2 \\
\mathrm{~N}=15\end{array}$ & $\begin{array}{c}\text { Gruppe } 3 \\
\mathrm{~N}=15\end{array}$ & $\begin{array}{c}\text { Gruppe } 4 \\
\mathrm{~N}=16\end{array}$ \\
\hline \multirow{2}{*}{ Alter } & 4,56 & 2,56 & 1,17 & 3,08 \\
\hline & $( \pm 1,21)$ & $( \pm 1,12)$ & $( \pm 1,16)$ & $( \pm 1,09)$ \\
\hline \multirow{2}{*}{ Zucht } & 8,39 & 12,47 & 8,93 & 7,73 \\
\hline & $( \pm 2,72)$ & $( \pm 2,53)$ & $( \pm 2,62)$ & $( \pm 2,45)$ \\
\hline \multirow{2}{*}{ Leistung } & 5,69 & 6,78 & 5,14 & 3,52 \\
\hline & $( \pm 1,24)$ & $( \pm 1,33)$ & $( \pm 1,37)$ & $( \pm 1,29)$ \\
\hline \multirow{2}{*}{ Unfruchtbarkeit } & 21,85 & 25,87 & 23,50 & 42,21 \\
\hline & $( \pm 2,69)$ & $( \pm 2,51)$ & $( \pm 2,60)$ & $( \pm 2,43)$ \\
\hline \multirow{2}{*}{ Mastitis } & $10,62^{a}$ & $12,76^{a}$ & $15,81 \mathrm{ab}$ & $19,26^{b}$ \\
\hline & $( \pm 2,14)$ & $( \pm 1,99)$ & $( \pm 2,06)$ & $( \pm 1,93)$ \\
\hline \multirow{2}{*}{ Melkbarkeit } & 2,72 & 2,27 & 2,52 & 2,38 \\
\hline & $( \pm 0,77)$ & $( \pm 0,72)$ & $( \pm 0,74)$ & $( \pm 0,69)$ \\
\hline \multirow{2}{*}{ Klauen } & $14,46^{\mathrm{ab}}$ & $18,02^{a}$ & $11,98^{b}$ & $14,46^{a b}$ \\
\hline & $( \pm 1,80)$ & $( \pm 1,68)$ & $( \pm 1,74)$ & $( \pm 1,62)$ \\
\hline \multirow{2}{*}{ Stoffwechsel } & $5,30 a b$ & $3,90^{a}$ & 6,26 ab & $7,63^{b}$ \\
\hline & $( \pm 1,43)$ & $( \pm 1,28)$ & $( \pm 1,48)$ & $( \pm 1,34)$ \\
\hline Sonstige & 9,49 a & $7,82^{a}$ & $2,83^{b}$ & $5,25^{\mathrm{ab}}$ \\
\hline Erkrankungen & $( \pm 1.61)$ & $( \pm 1,50)$ & $( \pm 1.55)$ & $( \pm 1,45)$ \\
\hline
\end{tabular}

$a, b$ Werte innerhalb einer Reihe mit verschiedenen Beschriftungen unterscheiden sich signifikant mit $\mathrm{P}<0,05$. 


\section{Milchleistung und -inhaltsstoffe im Jahresverlauf}

Die Parameter im Zeitverlauf sind in Abbildung 2.3.1, jeweils für die Monate Januar bis Dezember dargestellt. Für jeden Monat wurde der Durchschnitt der Jahre 2012 bis 2015 verwendet. Die Milchleistung (ECM) wird hier als Tagesmilchleistung angegeben und zeigte für die Gruppen mit mehr als sechs Stunden Weidezugang pro Tag geringere Werte als für die Gruppen mit weniger als sechs Stunden oder ganz ohne Weidezugang. Somit lagen G1 und G2 mit etwa 27 bis $30 \mathrm{~kg} /$ Tier und Tag im Jahresverlauf niedriger als G3 und G4 mit etwa 30 bis 32 kg/ Tier und Tag. Für alle Gruppen lässt sich ein Trend erkennen, dass in der ersten Jahreshälfte (Januar - Juni) mehr Milchleistung erbracht wurde, als in der zweiten Jahreshälfte (Juli - Dezember). Insbesondere G1 zeigte große Schwankungen zwischen der Stallund Weidesaison ( $\pm 3 \mathrm{~kg}$ Tagesmilchleistung). Für diese Gruppe begann der Rückgang der Milchleistung im April und sank kontinuierlich bis November. Fett- und Eiweißgehalte der Milch zeigten in der warmen Jahreszeit (April - September) einen deutlichen Rückgang für alle Gruppen. Für die Zellzahlen gab es von Juni bis September einen Anstieg für G2, G3 und G4, wobei für G3 der Peak nach oben am deutlichsten zu erkennen war. G1 zeigte bei den Zellzahlen häufiger schwankende Ergebnisse mit den höchsten Werten im Februar, Juli und Dezember. Von Juni bis September zeigten G1 und G2 mit vielen Weidestunden einen Anstieg des Harnstoffgehaltes, G3 und G4 zeigten dagegen wenig Schwankungen über das Kalenderjahr hinweg. Der prozentuale Anteil der Herde, mit einem FEQ $<1$ erhöhte sich für die Gruppen mit Weidezugang (G1, G2, G3) im Mai bis zum September. Insbesondere G1 zeigte in den Monaten Juni bis August einen bis zu 10\% höheren Anteil der Herde mit einem $F E Q<1$. G4 zeigte im Jahresverlauf kaum Schwankungen dieses Parameters, allerdings waren die Werte ganzjährig, mit 12 bis $15 \%$ der Herde, höher im Vergleich zu den anderen Gruppen. Von April bis Oktober hatten G1 und G2 weniger Tiere mit einem FEQ > 1,5. Für G3 und G4 zeigten sich hier keine nennenswerten Unterschiede im Jahresverlauf. Nutzungsdauer, Totgeburten- und Abgangsrate blieben bei allen vier Gruppen im Jahresverlauf konstant, da für diese Parameter nur jährliche Daten zur Verfügung standen. 

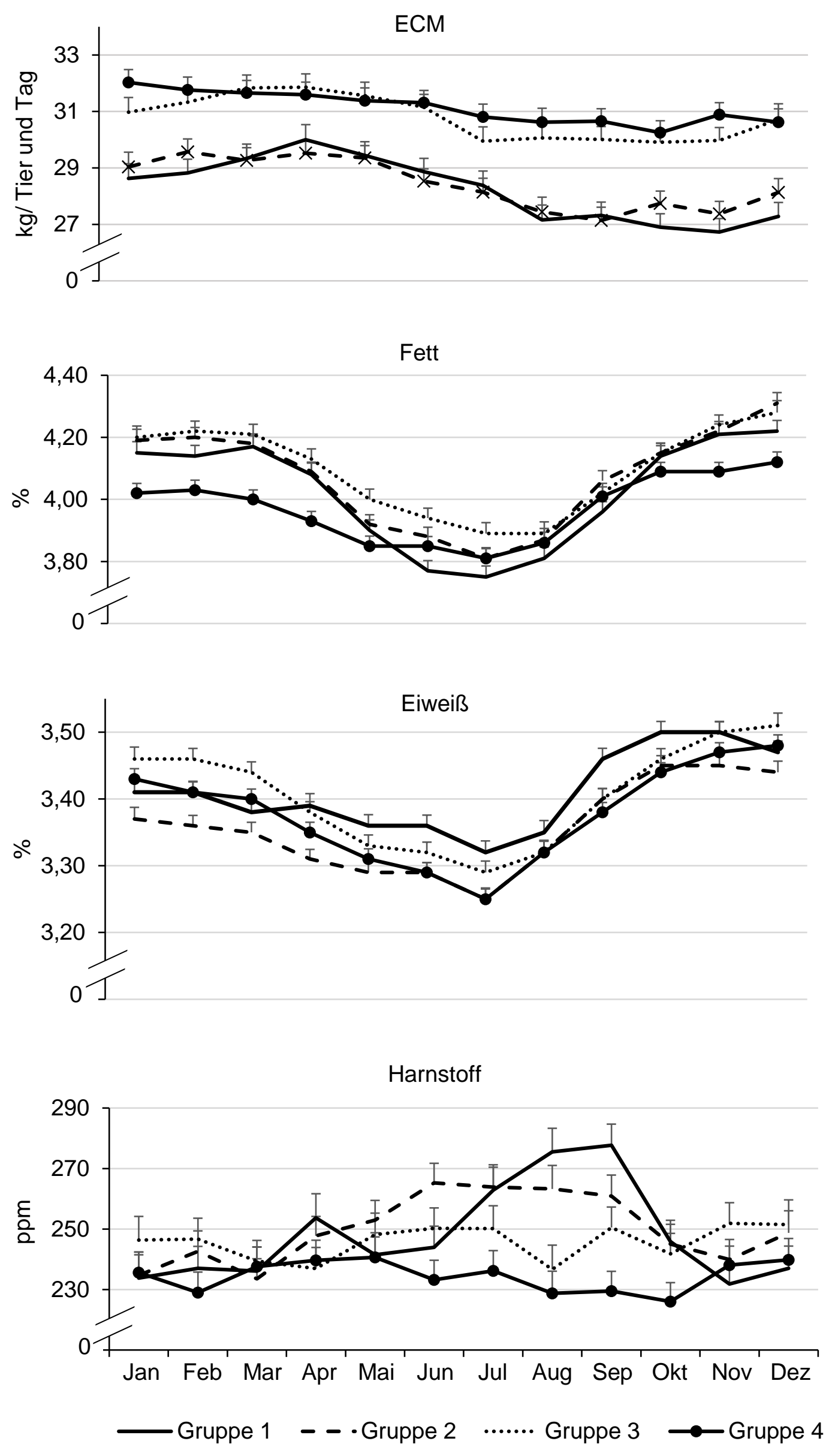

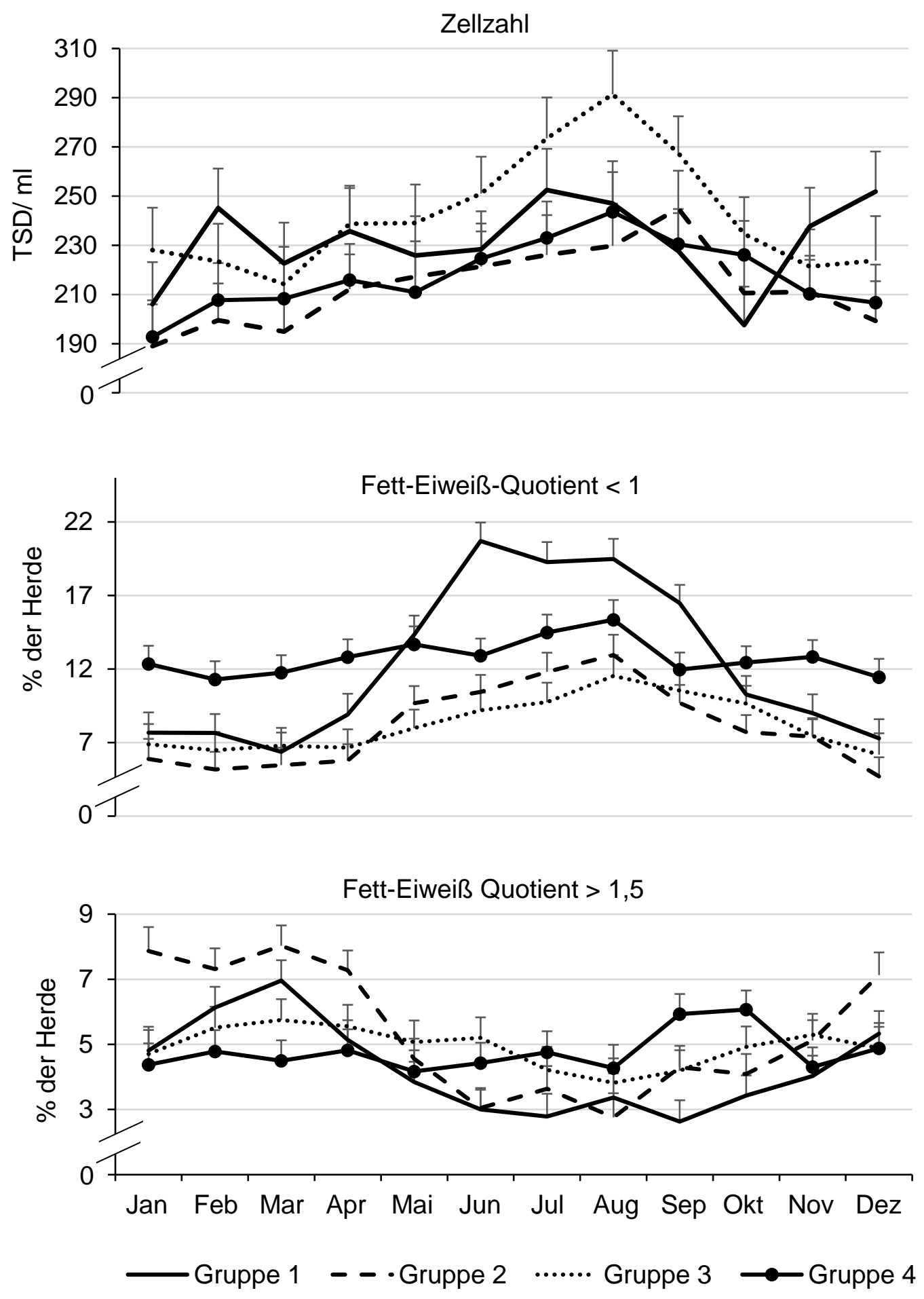

Abbildung 2.3.1 Entwicklung der Parameter ECM, Fett, Eiweiß, Zellzahl, Harnstoff und FettEiweiß-Quotient für die Jahre 2012 bis 2015 im Jahresverlauf von 61 Milchviehbetrieben mit $>10$ Stunden (G1), 6 bis 10 Stunden (G2), < 6 Stunden Weidegang/ Tag (G3) oder ohne Weidezugang (G4) 
Tabelle 2.3.4 Pearson-Korrelationen zwischen Leistungs- und Gesundheitsparametern von 61 Milchviehbetrieben (nur Korrelationen mit $\mathrm{P}<0,1$ )

\begin{tabular}{|c|c|c|c|c|c|c|c|c|c|c|c|}
\hline & $\begin{array}{c}\text { BCS }^{1} \\
\text { „Zu dünn“ }\end{array}$ & $\begin{array}{l}\text { Haarlose } \\
\text { Stellen }\end{array}$ & Läsionen & $\begin{array}{c}\text { Dreckiges } \\
\text { Euter }\end{array}$ & $\begin{array}{c}\text { Dreckige } \\
\text { Flanke }\end{array}$ & $\begin{array}{l}\text { Leicht } \\
\text { lahm }\end{array}$ & $\begin{array}{c}\text { Schwer } \\
\text { lahm }\end{array}$ & $\mathrm{ECM}^{2}$ & Zellzahl & Abgangsrate & $\begin{array}{l}\text { Zellzahl } \\
\leq 100.000\end{array}$ \\
\hline Läsionen & & & & $\begin{array}{c}0,495 \\
(<0,01)\end{array}$ & $\begin{array}{l}0,231 \\
(<0,1)\end{array}$ & $\begin{array}{c}0,357 \\
(<0,01)\end{array}$ & $\begin{array}{c}0,469 \\
(<0,01)\end{array}$ & & & & \\
\hline $\begin{array}{l}\text { Dreckige } \\
\text { Flanke }\end{array}$ & & & & & & & $\begin{array}{c}0,351 \\
(<0,05)\end{array}$ & & & & \\
\hline Leicht lahm & & & & & & & $\begin{array}{c}0,435 \\
(<0,01)\end{array}$ & & & $\begin{array}{l}0,239 \\
(<0,1)\end{array}$ & \\
\hline $\begin{array}{c}\text { Schwer } \\
\text { lahm }\end{array}$ & & & & & & & & $\begin{array}{l}-0,237 \\
(<0,1)\end{array}$ & $\begin{array}{c}0,265 \\
(<0,05)\end{array}$ & $\begin{array}{c}0,281 \\
(<0,05)\end{array}$ & \\
\hline Zellzahl & & & & & & & & & & $\begin{array}{c}0,411 \\
(<0,01)\end{array}$ & $\begin{array}{c}-0,712 \\
(<0,01)\end{array}$ \\
\hline Abgangsrate & & & & & & & & & & & $\begin{array}{c}-0,325 \\
(<0,05)\end{array}$ \\
\hline
\end{tabular}

${ }^{1}$ BCS $=\%$ der Tiere mit Body Condition Score $=$ „zu dünn““.

${ }^{2} \mathrm{ECM}=$ Energie korrigierte Milchmenge. 


\section{Korrelationen von Leistungs- und Gesundheitsparametern}

Tabelle 2.3.4 zeigt ausgewählte Korrelationen zwischen Leistungs- und Gesundheitsparametern der Betriebe. Gab es vermehrt Tiere mit dem BCS „zu dünn“ auf einem Betrieb, so zeigten sich dort auch vermehrt Läsionen $(r=0,368, P<0,01)$, mehr Tiere mit dreckigem Euter $(r=0,354, P<0,01)$, schwer lahme Tiere $(r=0,320, P<0,05)$ und die Milchleistung war tendenziell geringer $(r=-0,232, P<0,1)$. Haarlose Stellen waren positiv korreliert mit leichten Lahmheiten $(r=0,334, P<0,05)$ Desweiteren war die Anzahl von Läsionen positiv mit dem Auftreten von leichten $(r=0,357, P<0,01)$ und schweren Lahmheiten $(r=0,469, P<0,01)$ sowie mit dreckigen Eutern $(r=0,495, P<0,01)$ korreliert. Bei vermehrt verschmutzten Eutern, traten auch signifikant häufiger schwere Lahmheiten $(r=0,457, P<0,01)$ auf. Auch dreckige Flanken der Tiere zeigten positive Korrelationen mit schweren Lahmheiten $(r=0,351$, $P<0,05)$. Leichte Lahmheiten zeigten eine Tendenz zu höheren Abgangsraten $(r=0,239$, $P<0,1)$. Schwere Lahmheiten zeigten ebenfalls eine positive Korrelation zu den Abgangsraten $(r=0,281, P<0,05)$ sowie $z u$ den Zellzahlen $(r=0,265, P<0,05)$. Auf Betrieben mit hoher Milchleistung gab es geringere Zellzahlen $(r=-0,318, P<0,05)$ und insbesondere auch mehr Tiere mit einer Zellzahl von $\leq 100.000(r=0,303, P<0,05)$. Zellzahlen waren positiv korreliert mit Abgängen im Betrieb $(r=0,411, P<0,01)$ und gleichzeitig waren Tiere mit einer Zellzahl von $\leq 100.000$ negativ korreliert mit der Abgangsrate $(r=-0,325, P<0,01)$.

Für die Parameter Fett (\%), Eiweiß (\%), Harnstoffgehalt (ppm), Nutzungsdauer (Jahre), FEQ > 1,5 (\%) und Totgeburtenrate (\%) wurden keine signifikanten Korrelationen zu den genannten Parametern gefunden.

\section{Stalleinrichtung}

Als Parameter der Stalleinrichtung zeigten die LS Means Werte sowohl beim TLV (G1: 2,21 $\pm 0,63, \mathrm{G} 2: 2,07 \pm 0,62$, G3: $1,38 \pm 0.67, \mathrm{G} 4: 1,33 \pm 0.62)$ als auch beim TFV (G1: 1,29 $\pm 0,10$, G2: $1,35 \pm 0,10, G 3: 1,35 \pm 0,11, G 4: 1,13 \pm 0,10)$ keine signifikanten Unterschiede $(P>0,05)$. Außerdem wurden das TLV und das TFV auf Korrelationen zu Gesundheits- und Leistungsparametern überprüft. Das TLV $(T L V<1=$ für jedes Tier mehr als ein Liegeplatz vorhanden) war negativ mit dem Auftreten von haarlosen Stellen $(r=-0,262, P<0,05)$ und mit der Milchleistung (ECM) $(r=-0.280, P<0,05)$ korreliert. Ebenso stand das TLV positiv mit der Abgangsrate in Beziehung $(r=0,366, P<0,01)$. Zudem hatten bei einem niedrigen TLV mehr Tiere eine Zellzahl von $\leq 100.000(r=-0,270, P<0,05)$ und gleichzeitig weniger Tiere eine Zellzahl von $>400.000(r=0,315, P<0,05)$ sowie weniger Tiere einen $F E Q<1 \quad(r=0,316$, $P<0,05)$. Betriebe mit einem niedrigen TFV $(T F V<1=$ für jedes Tier mehr als ein Fressplatz vorhanden), zeigten höhere Eiweiß-Gehalte in der Milch $(r=-0,363, P<0,01)$ und geringere Harnstoffwerte $(r=0,321, P<0,05)$. Darüber hinaus war das TFV negativ mit dem Anteil an Tieren mit einem FEQ $<1(r=-0,300, P<0,05)$ korreliert. 
In G1 und G3 wurden die Liegeboxen auf jeweils 27\% der Betriebe mit "gut" und auf jeweils 73\% der Betriebe mit „mangelhaft“ bewertet. In G2 erhielten $40 \%$ der Betriebe eine Bewertung ihrer Liegeboxen mit "gut“ und 60\% eine Bewertung mit „mangelhaft“. In G4 wurden die Liegeboxen auf $38 \%$ der Betriebe mit „gut“ bewertet und auf $62 \%$ mit „mangelhaft“.

Die Liegeboxenabmessungen zeigten, dass mit "gut“ bewertete Liegeboxen im Vergleich zu „mangelhaft“ bewerteten Liegeboxen weniger Tiere mit Läsionen $(9,92$ vs. 16,13, $P<0,01)$, höhere Zellzahlen (236,52 vs. 193,70, $\mathrm{P}<0,05)$, mehr Tiere mit Zellzahlen $>400.000$ (12,20 vs.10.36; $P<0,01)$ und eine Tendenz zu längerer Nutzungsdauer (44,45 vs. 40,59, $P<0,1)$ aufwiesen. Liegeboxenmaße zeigten keine Effekte auf die Anzahl von lahmen Tieren, auf die Totgeburten- und Abgangsrate, Harnstoffgehalte, FEQ, den BCS und auch nicht auf Integumentschäden. Betriebe mit Hochboxen zeigten im Vergleich zu Betrieben mit Tiefboxen mehr schwer lahme Tiere (8,81 vs. $6,19, \mathrm{P}<0,05)$, mehr Tiere mit haarlosen Stellen $(58,75$ vs. 43.05, $\mathrm{P}<0,01)$, mehr Tiere mit Zellzahlen $<100.000(61,06$ vs. 54,00, $\mathrm{P}<0,05)$ sowie eine Tendenz zu mehr Tieren mit Läsionen (17,42 vs. 9,86, $\mathrm{P}<0,1)$ und zu mehr Tieren mit einem BCS „zu dünn“ $(13,15$ vs. 10,86, $P<0,1)$. Ob ein Betrieb mit Hoch- oder Tiefboxen ausgestattet war, hatte keine Auswirkungen auf die Anzahl der Tiere mit leichten Lahmheiten, die Abgangs- und Totgeburtenrate, Harnstoffgehalte, FEQ, auf die Zellzahlen und auch nicht auf die Milchmenge.

\section{Diskussion}

\section{Gruppenunterschiede von Leistungs- und Gesundheitsparametern}

Betriebe mit wenig oder gar keiner Weidehaltung zeigten in dieser Studie eine höhere Milchleistung als Betriebe mit vielen Weidestunden. Auch REHN et al. (2000) beschrieben, dass insbesondere hochleistende Rassen durch die Weidehaltung, an Milchmenge verlieren können. In den Untersuchungen von SMITH et al. (2013), sank die Milchleistung signifikant bei Holstein-Friesian Kühen, die Hitzestress ausgesetzt waren, der bei Weidehaltung insbesondere für große Herden häufig nicht vermieden werden kann, da nicht genügend Schatten zur Verfügung steht. DILLON et al. (2005), EVERS et al. (2008), STEINWIDDER et al. (2010) und KIEFER (2014) zeigten dennoch, dass trotz Weidehaltung durch geringere Futterkosten und durch gutes Weidemanagement, gleichwertige oder bessere monetäre Betriebsergebnisse erzielt werden können.

Anders als in der vorliegenden Studie, in der nur geringfügige Unterschiede zwischen Eiweißund Fettgehalten der Milch festgestellt werden konnten, zeigten O'CALLAGHAN et al. (2016), dass Milch von Kühen, die Weidezugang erhielten, signifikanten höhere Konzentrationen an Fett und Eiweiß enthielt, als Milch von Kühe aus ganzjährig stallhaltenden Betrieben. Die deutlicheren Ausprägungen von unterschiedlichen Fett und Eiweißgehalten bei O'CALLAGHAN 
et al. (2016) könnten zum einen in der Einteilung der Gruppen begründet sein, die sich nur in „Weide“ und „keine Weide“ unterschieden. Zum anderen waren die Weidetiere aber auch so ausgewählt, dass ein Großteil der Futterration auf der Weide aufgenommen wurde, in der vorliegenden Studie war dies keine Bedingung.

Auch DECHOw et al. (2011) untersuchte Unterschiede zwischen ganzjährig im Laufstall gehaltenen Milchkühen und Milchkühen mit Laufstall und Weidezugang. Wie auch in der vorliegenden Studie konnten DECHOW et al. (2011) lediglich geringe Unterschiede zwischen dem mittleren Zellzahl Score der Tiere ohne (2.92) und mit Weidezugang (3.02) feststellen. Jedoch zeigten sich in der vorliegenden Studie Abgänge aufgrund von Mastitis Erkrankungen in der Gruppe ohne Weidehaltung signifikant häufiger als in den Gruppen mit vielen Weidestunden. Zudem zeigten DECHOW et al. (2011) auch, dass der Anteil von Kühen mit einem $\mathrm{FEQ}<1$, welcher die Wahrscheinlichkeit für fütterungsbedingten Stoffwechselstress erhöht, sich nur geringfügig zwischen Betrieben ohne und mit Weidehaltung unterschied $(14,1 \%$ vs. $15,1 \%)$. Auch in der vorliegenden Studie konnte kein einheitliches Bild gezeigt werden, ob Weide- oder Stallhaltung einen FEQ von < 1 begünstigt, da sowohl G1, als auch G4 mit etwas über $12 \%$ einen höheren Herdenanteil mit einem $F E Q<1$ zeigten als $\mathrm{G} 2$ und G3. Die Nutzungsdauer unterschied sich in der vorliegenden Studie dahingehend, dass G2 höhere Werte aufwies als die drei anderen Gruppen, die sich untereinander jedoch nicht weiter unterschieden. DECHOW et al. (2011) zeigten auch, dass auf Betrieben mit Weidehaltung signifikant mehr Kühe ein höheres Alter ( $\geq 6$ Jahre und $\geq 5$ Laktationen) erreichten als auf Betrieben mit ganzjähriger Stallhaltung oder mit Zugang zu einem Laufhof.

Die Ergebnisse der Parameter zur Tiergesundheit, bezogen auf das WQP, sind ausführlich in Kapitel 2.1 dieser Arbeit diskutiert.

\section{MLP-Parameter im Zeitverlauf}

In der ersten Jahreshälfte produzierten alle Gruppen mehr Milch als in der zweiten Jahreshälfte. Ab November lässt sich jedoch für alle Gruppen mit Weidehaltung wieder ein leichter Aufwärtstrend feststellen. Von OETZEL (2007) wurden 1,2 Mio. Tiere aus 10.980 Milchviehherden untersucht, die ebenfalls ein deutliches Absinken der Milchleistung ab Juni im Jahresverlauf feststellten (durchschnittlich $\pm 3 \mathrm{~kg}$ ) sowie einen Wiederanstieg ab November. Der Abfall der Milchleistung ab Juni kann nach AVENDAÑo-REYES (2012) mit Hitzestress begründet werden, aber auch mit der schlechteren Körperkondition während der Weidesaison. AMMER et al. (2016) zeigten bereits, dass Milchkühe auch unter gemäßigten klimatischen Bedingungen, wie sie in Niedersachsen gegeben sind, Hitzestress ausgesetzt sein können. Insbesondere die Gruppe mit mehr als 10 Stunden Weidezugang pro Tag zeigte große Schwankungen der Milchleistung zwischen der Stall- und Weidesaison. Ab November bis zum Peak im April stieg die Milchleistung für G1 von $27 \mathrm{~kg}$ auf $30 \mathrm{~kg}$, fiel aber ab April, für viele 
Betriebe auch der Start der Weidesaison in Niedersachsen, wieder kontinuierlich ab. Auch Fett- und Eiweißgehalte waren in der vorliegenden Studie während der warmen Jahreszeit geringer als im Winter. Vergleichbare Ergebnisse zeigte auch BERNABUCCI et al. (2015), die ebenfalls Holstein-Friesian Kühe untersuchten und geringste Werte von Fett und Eiweiß im Sommer und höchste Werte im Winter feststellten. OETZEL (2007) zeigte ebenfalls einen Rückgang des Fettgehaltes im Sommer ( $\pm 0,3$ Prozentpunkte) und begründete diesen Rückgang, wie auch STAPLES und THATCHER (2011), mit Hitzestress bedingter Beeinflussung des Pansens, sowie atypischem Fressverhalten aufgrund von Hitzestress. Wie auch in dieser Studie, zeigte OETZEL (2007) einen geringeren Eiweißgehalt von bis zu 0,2 Prozentpunkten im Sommer.

BERNABUCCI et al. (2015) stellten, wie auch die vorliegende Studie, heraus, dass die Zellzahlen in den Sommermonaten, im Vergleich zum Winter und Frühling, anstiegen. Auch ARCHER et al. (2013) fanden höhere Zellzahlen im Frühling und Sommer als im Herbst und Winter bei Irischen, Englischen und Walisischen Milchkühen. ARCHER et al. (2013) begründeten die Ergebnisse mit einer Überbelegung der vorhandenen Weideflächen und damit verbundenem schlechten Weidemanagement. STAPLES und THATCHER (2011) und SMITH et al. (2013) zeigten ebenfalls signifikant höhere Zellzahlen bei Kühen, die Hitzestress ausgesetzt wurden, im Vergleich zu Kühen ohne Hitzestress.

Der Anteil der Herde mit einem FEQ $<1$ stieg in den Sommermonaten, insbesondere für die Weidegruppen, deutlich an. Dies lässt sich zurück führen auf den verminderten Fettgehalt der Milch in den Sommermonaten. Zwar ging der Eiweißgehalt in diesem Zeitraum ebenfalls zurück, allerdings mit nur etwa 0,2 Prozentpunkten im Vergleich zum Fettgehalt mit durchschnittlich 0,4 Prozentpunkten. Auch STAPLES und THATCHER (2011) fanden durch Hitzestress bedingte, verminderte Fett- und Eiweiß-Werte. Bei ihren Untersuchungen zeigte sich ebenfalls ein Rückgang des Fettgehaltes um etwa 0,5 Prozentpunkte und des Eiweißgehaltes um 0,2 Prozentpunkte während der Sommermonate.

\section{Korrelationen zwischen Leistungs- und Gesundheitsparametern}

Ein zu geringer BCS zeigte in dieser Studie nicht nur Auswirkungen auf gesundheitliche Parameter, wie höhere Prävalenzen von Läsionen und schweren Lahmheiten, sondern auch einen tendenziell negativen Einfluss auf die Milchleistung. RANDALL et al. (2015) und WESTIN et al. (2016) zeigten ebenfalls, dass ein geringer BCS bei Milchkühen das Risiko einer Lahmheit erhöht und deshalb auch verstärkt das Management hinsichtlich eines optimalen BCS ausgerichtet werden sollte. Die Autoren vermuteten unter anderem ein zu gering ausgeprägtes Ballenpolster an der Klaue, bei insgesamt zu niedrigem Körpergewicht, als mögliche Erklärung für das steigende Lahmheitsrisiko bei mageren Tieren. Einen Nachweis für den signifikanten Einfluss des BCS auf die Milchleistung erbrachten MULLER (2003) und 
ROCHE et al. (2007). Sie zeigten, dass ein zu geringer BCS, insbesondere im Zeitraum des Kalbens, zu einer geringeren Milchmenge in der folgenden Laktation führte. Nach RocHE et al. (2007) sollte daher ein BCS von 3,5 (bei einer 5-Punkte-Skala) zum Kalbezeitpunkt angestrebt werden. In dieser Studie zeigten Betriebe mit hoher Milchleistung geringere Zellzahlen, gegenteilig zu den Ergebnissen von FLEISCHER et al. (2001). Beschreibt man die Erfassung der Zellzahlen als indirekte Messmethode für Mastitis Erkrankungen (KoIVULA et al., 2005), so zeigen die Ergebnisse von FLEISCHER et al. (2001) bei hoher Milchleistung signifikant höhere Zellzahlen und damit erhöhte Mastitis Prävalenzen.

\section{Stalleinrichtung}

War das TLV niedrig und damit mehr Liegeboxen pro Kuh vorhanden, zeigten sich eine höhere Milchleistung, geringere Abgangsraten, es gab mehr Tiere mit geringen Zellzahlen und weniger Tiere mit einem FEQ $<1$. Trotz der gesundheitlichen Vorteile hatten nur 29 von 60 Betrieben ein TLV $\leq 1$. Ähnlich verhielt es sich mit dem TFV, hier hatten nur 25 von 60 Betrieben ein TFV $\leq 1$, wobei auch hier Vorteile wie höhere Eiweiß-Gehalte in der Milch, geringere Harnstoffwerte und mehr Tiere mit einen FEQ $<1$ festgestellt werden konnten.

Als Vergleichsgrößen ob eine Liegebox als „gut“ oder „mangelhaft" eingestuft wurde, wurden Angaben der NRW Bauschrift Milchviehhaltung in leicht angepasster Form verwendet (LK NRW, 2012). Die Höhe des Nackenriegels sollte in diesen Untersuchungen nicht unter $120 \mathrm{~cm}$ liegen, die Länge der Box vom Boxenende bis zum Nackenriegel sollte mindestens $160 \mathrm{~cm}$ betragen, Die Höhe des Durchlaufschutzes sollte nicht niedriger als $110 \mathrm{~cm}$ sein, Die Gesamtlänge der Liegebox sollte $280 \mathrm{~cm}$ und die Breite der Liegebox $120 \mathrm{~cm}$ nicht unterschreiten. Alle Werte konnten jeweils um bis zu 5\% abweichen, bevor sie mit „mangelhaft“ bewertet wurden. Nur 20 der 61 Betriebe hatten Liegeboxen mit den Abmessungen, die diese Vorgaben erfüllten. Das unterstützt auch die Ergebnisse von WESTIN et al. (2016), die nur auf einem von 36 untersuchten Milchviehbetrieben Liegeboxen vorfanden, die den Anforderungen entsprachen und damit breit und lang genug für die untersuchten Tiere waren.

„Mangelhafte“ Liegeboxen zeigten in dieser Studie signifikant weniger Zellzahlen und auch weniger Tiere mit Zellzahlen > 400.000 im Vergleich zu Liegeboxen, die als „gut" eingestuft wurden. Eine mögliche Erklärung für dieses Ergebnis wäre die geringere Belastung von Kot und Urin im Bereich des Euters in der Liegebox. Durch kurze Liegeboxen oder falsch eingestellte Nackenriegel gelangen weniger Exkremente in die Liegebox als bei großzügiger gestalteten Boxen. In dieser Studie konnten keine signifikanten Zusammenhänge zwischen den Abmessungen der Liegeboxen und Lahmheiten festgestellt werden. WESTIN et al. (2016) zeigte jedoch eine signifikante Korrelation zwischen der Breite der Liegeboxen und Prävalenzen von Lahmheiten. Die Autoren empfahlen daher eine genauere Beachtung der tiergerechten Liegeboxenmaße oder eine Selektion der Tiere für kleinere Liegeboxen. In der 
vorliegenden Studie konnte jedoch ein deutlich erhöhter Anteil an schwer lahmen Kühen festgestellt werden, wenn ein Betrieb mit Hochboxen anstelle von Tiefboxen ausgestattet war. Bei Hochboxen zeigten sich außerdem deutlich mehr Integumentschäden als bei Tiefboxen. Auch WeCHSLER et al. (2000), KANSWOHL und SANFTLEBEN (2006) und ZäHNER et al. (2009) zeigten bereits eine höhere Anzahl von haarlosen oder verschorften Stellen sowie Schwellungen und offene Wunden bei Hochboxen, auch mit qualitativ hochwertigen Gummimatten, im Vergleich zu Tiefboxen. VAN GASTELEN et al. (2011) und BRENNINKMEYER et al. (2013) fanden geringere Prävalenzen und Schweregrade von Tarsalgelenksverletzungen in Betrieben mit Tief- anstelle von Hochboxen. BERGSTEN et al. (2016) zeigten außerdem vermehrte Ballenfäuleerkrankungen, Weiße Linie Defekte sowie Sohleneinblutungen und Sohlengeschwüre in Hochboxen im Vergleich zu Tiefboxen. Milchkühe haben diesen Studien zufolge verbesserte Gesundheitsparameter und einen höheren Liegekomfort in gut gepflegten Tiefboxen als in Hochboxen (BAK et al., 2016).

\section{Schlussfolgerungen}

Basierend auf den Ergebnissen der vorliegenden Arbeit kann geschlussfolgert werden, dass zwar verschiedene gesundheitliche Parameter, wie Körperkondition, Lahmheiten und Integumentschäden, deutlich positiv durch die Weidesaison beeinflusst werden konnten, Leistungsparameter zeigten dagegen für Betriebe mit ganzjähriger Stallhaltung eine höhere Milchleistung sowie im Jahresverlauf konstantere Ergebnisse für den Fettgehalt der Milch, dem Anteil der Herde mit einem FEQ $<1$ und für die Harnstoffgehalte. G4 zeigte jedoch signifikant mehr Abgänge aufgrund von Mastitis Erkrankungen im Vergleich zu den beiden Gruppen mit mehr als sechs Stunden Weidezugang. Verbesserte Ergebnisse für einen Großteil der Leistung- oder Gesundheitsparameter bei einer bestimmten täglichen Weidedauer, konnten in dieser Studie nicht gezeigt werden. Jedoch zeigte G2 mit 6-10 Stunden Weidegang pro Tag eine signifikant geringere Abgangsrate und höhere Nutzungsdauer als die anderen drei Gruppen und deutlich weniger Tiere mit einem FEQ $<1$ als $G 1$ und G4. Auch bei Differenzierung der Stalleinrichtung konnten deutliche Unterschiede zwischen Hoch- und Tiefboxen bzw. den TLV und TFV festgestellt werden. Hochboxen anstelle von Tiefboxen sowie zu wenig Liege- und Fressplätze, zeigten signifikant negative Einflüsse auf Milchleistung, Abgangsraten, Integumentschäden, Eiweißgehalte, Harnstoffwerte und Lahmheiten. 


\section{Literatur}

Ammer, S., C. Lambertz und M. Gauly (2016): Can the reticular temperature be used as an indicator for heat stress in dairy cattle? Journal of Dairy Science 99, 10067-10076.

Archer, S.C., F. Mc Coy, W. Wapenaar und M.J. Green (2013): Association of season and herd size with somatic cell count for cows in Irish, English, and Welsh dairy herds. Veterinary Journal,196 (3), 515-521.

Avendaño-Reyes, L. (2012): Heat stress management for milk production in arid zones, milk production - an up-to-date overview of animal nutrition, management and health. Narongsak Chaiyabutr (Ed.), InTech.

Bak, A.S., M.S. Herskin und M.B. Jensen (2016): Effect of sand and rubber surface on the lying behavior of lame dairy cows in hospital pens. Journal of Dairy Science 99 (4), 28752883.

Bergsten, C., E. Telezhenko und M. Ventorp (2016): Influence of soft or hard floors before and after first calving on dairy heifers locomotion, claw and leg health. Animals 5, 662-668.

Bernabucci, U., L. Basiricò, P. Morera, D. Dipasquale, A. Vitali, F. Piccioli Cappelli und L. Calamari (2015): Effect of summer season on milk protein fractions in Holstein cows. Journal of Dairy Science 98 (3), 1815-1827.

Brenninkmeyer, C., S. Dippel, J. Brinkmann, S. March, C. Winckler und U. Knierima (2013): Hock lesion epidemiology in cubicle housed dairy cows across two breeds, farming systems and countries. Preventive Veterinary Medicine 109, 236-245.

Burow, E. (2012): Welfare of dairy cows in Danish summer grazing herds. Öffentliche Disputation, Aarhus Universität, Aarhus, Dänemark.

Dechow, C.D., E.A. Smith und R.C. Goodling (2011): The effect of management system on mortality and other welfare indicators in Pennsylvania dairy herds. Animal Welfare, 20: 145-158.

Dillon, P., J.R. Roche, L. Shalloo und B. Horan (2005): Optimising financial returns from grazing in temperate pastures. Utilisation of Grazed Grass in Temperate Animal Systems. Tagungsband: international Grassland Congress, Cork, Ireland. Wageningen Academic Publishers, Wageningen, Niederlande, 131-147.

Evers, A.G., M.H.A. de Haan, A. van den Pol-Van Dasselaar und A.P. Philipsen (2008): Weiden onder moeilijke omstandigheden. Een studie naar inkomensverschillen tussen weiden en opstallen. Animal Sciences Group Wageningen UR, Lelystad.

Kanswohl, N. und P. Sanftleben (2006): Analyse und Bewertung von Hoch- und Tiefboxen für Milchrinder aus arbeitswirtschaftlicher, ethologischer, hygienischer und ökonomischer Sicht. Landesforschungsanstalt für Landwirtschaft und Fischerei MecklenburgVorpommern, Institut für Tierproduktion, Forschungsbericht-Nr.: 1/13, 1-36. 
Koivula, M., E. A. Mantysaari, E. Negussie, und T. Serenius (2005): Genetic and Phenotypic Relationships Among Milk Yield and Somatic Cell Count Before and After Clinical Mastitis. Journal of Dairy Science 8, 827-833.

Fleischer, P., M. Metzner., M. Beyerbach., M. Hoedemaker und W. Klee (2001): The Relationship Between Milk Yield and the Incidence of Some Diseases in Dairy Cows. Journal of Dairy Science 84 (9), 2025-2035.

Hernandez-Mendo, O., M.A.G. von Keyserlingk, D.M. Veira und D.M. Weary (2007): Effects of pasture on lameness in dairy cows. Journal of Dairy Science 90, 1209-1214.

Kiefer, L. (2014): Gesamtbetriebliche Analyse von Weidebetrieben und Weidesystemen in der Milchviehhaltung in unterschiedlichen Regionen Süddeutschlands. Dissertation. Universität Hohenheim.

Leisen, E. (2014): Weidebasierte Milchviehhaltung in Deutschland. Grasland- und weidebasierte Milchproduktion, Mitteilungen der Arbeitsgemeinschaft Grünland und Futterbau Band 16, Internationale Weidetagung, Zollikofen, Schweiz (Hrsg. B. Reidy, B. Gregis und P. Thomet), 98-101.

LK NRW (2012): NRW Bauschrift Milchviehhaltung - Beratungsempfehlungen für den Bau und die Ausstattung von Milchviehställen. Landwirtschaftskammer NRW, Referat 24 Energie, Bauen, Technik, Münster.

Muller, L.D. (2003): Pasture, body condition and reproduction. In: Tagungsband „Nutrition of dairy cows on pasture-based systems“, März 2003, Grantville, Pennsylvania, United States, 79-81.

O'Callaghan, T.F., D. Hennessy, S. McAuliffe, K.N. Kilcawley, M. O'Donovan, P. Dillon, R.P. Ross und C. Stanton (2016): Effect of pasture versus indoor feeding systems on raw milk composition and quality over an entire lactation. Journal of Dairy Science 99 (12), 9424 9440.

Oetzel, G.R. (2007): Subacute Ruminal Acidosis in Dairy Herds: Physiology, Pathophysiology, Milk Fat Responses, and Nutritional Management. 40. Jahrestagung der „American Association of bovine practitioners", 17. September, 2007, Vancouver, Canada.

Olmos G., L. Boyle, A. Hanlo, J. Patton, J.J. Murphy und J.F. Mee (2009): Hoof disorders, locomotion ability and lying times of cubicle-housed compared to pasture based dairy cows. Livestock Science 125, 199-207.

Randall L.V., M. J. Green, M.G.G. Chagunda, C. Mason, S.C. Archer, L.E. Green, und J.N. Huxley (2015): Low body condition predisposes cattle to lameness: An 8-year study of one dairy herd. Journal of Dairy Science 98, 3766-3777.

Rehn, H., B. Berglund, U. Emanuelsson, G. Tengroth und J. Philipsson (2000): Milk production in Swedish dairy cows managed for calving intervals of 12 and 15 months. Animal Science 50, 263-271. 
Reijs, J., C. Daatselaar, J. Helming, J. Jager, und A. Beldman (2013): Grazing dairy cows in north-west Europe. LEI Report 2013-001. LEI Wageningen UR, Den Haag, Niederlande. Roche, J.R., J.M. Lee, K.A. Macdonald, und D.P. Berry (2007): Relationships Among Body Condition Score, Body Weight, and Milk Production Variables in Pasture-Based Dairy Cows. Journal of Dairy Science 90, 3802-3815.

Smith, D.L., T. Smith, B.J. Rude und S.H. Ward (2013): Short communication: Comparison of the effects of heat stress on milk and component yields and somatic cell score in Holstein and Jersey cows. Journal of Dairy Science 96, 3028-3033.

Staples, C.R. und W.W. Thatcher (2011): Stress in Dairy Animals - Heat Stress: Effects on Milk Production and Composition. Food Science, Encyclopedia of Dairy Sciences, 561566.

Steinwidder, A. und W. Starz (2006): Sind unsere Kühe für die Weide noch geeignet? Tagungsband der "Freiland-Tagung", September 2006. Veterinärmedizinische Universität, Wien, Österreich, 37-43.

Steinwidder, A., W. Starz, L. Podstatzky, L. Kirner, E.M. Pötsch, R. Pfister, und M. Gallenböck (2010): Low-Input Vollweidehaltung von Milchkühen im Berggebiet Österreichs Ergebnisse von Pilotbetrieben bei der Betriebsumstellung. Züchtungskunde 82, 241252.

Van Gastelen, S., B. Westerlaan, D.J. Houwers und F.J.C.M. van Eerdenburg (2011): A study on cow comfort and risk for lameness and mastitis in relation to different types of bedding materials. Journal of Dairy Science 94 (10), 4878-4888.

Washburn, S.P., S.L. White, J.T.Jr. Green und G.A. Benson (2002): Reproduction, mastitis, and body condition of seasonally calved Holstein and Jersey cows in confinement or pasture systems. Journal of Dairy Science 85, 105-111.

Wechsler B., J. Schaub, K. Friedli und R. Hauser (2000): Behaviour and leg injuries in dairy cows kept in cubicle systems with straw bedding or soft lying mats. Applied Animal Behaviour Science 69 (3), 189-197.

Welfare Quality (2012): Welfare Quality ${ }^{\circledR}$ assessment protocol for cattle applied to dairy cows. Welfare Quality® Consortium, Lelystad, Niederlande.

Weinrich, R., S. Kühl, A. Zühlsdorf und A. Spiller (2014): Consumer attitudes in Germany towards different dairy housing systems and their implications for the marketing of pasture raised milk. International Food and Agribusiness Management Review 17(4), 205-222.

Weiß, D. (2014): Weidebasierte Milchviehhaltung in Deutschland. Grasland- und weidebasierte Milchproduktion, Mitteilungen der Arbeitsgemeinschaft Grünland und Futterbau Band 16, Internationale Weidetagung, Zollikofen, Schweiz (Hrsg. B. Reidy, B. Gregis und P. Thomet), 43-48. 
Westin, R.A. Vaughan, A.M. de Passillé, T.J. DeVries, E.A. Pajor, D. Pellerin, J.M. Siegford, A. Witaifi, E. Vasseur und J. Rushen (2016): Cow- and far-level resk factors for lameness on dairy farms with automated milking systems. Journal of Dairy Science 99 (5), 3732 43.

Zähner, M., S. Schrade, W. Schaeren und J. Schmidtko (2009): Wiederkäuer: Haltung und Gesundheit: Neue Materialien als Einstreu in Liegeboxen von Milchviehställen. Tagungsband der 10. Wissenschaftstagung Ökologischer Landbau, ETH Zürich, Schweiz, 11.-13. Februar 2009, 50-53. 
3. Allgemeine Diskussion 


\subsection{Effekte des Weidezugangs auf das Tierwohl und die Tiergesundheit}

Um die Effekte des Weidezugangs auf das Tierwohl zu untersuchen, wurde für diese Studie das Welfare Quality assessment protocol (WQP; WELFARE QUALITY $®$, 2012) ausgewählt (Kapitel 2.1). Das WQP baut in erster Linie auf tierbezogenen Indikatoren auf und wurde auch bereits in anderen Studien auf Reliabilität und Validität überprüft und für gut befunden (GIESEKE et al., 2014). Das WQP beinhaltet auch die Klassifizierung der Betriebe in die Gesamtbewertung „exzellent“, „akzeptabel“, „verbessert“ und „nicht klassifiziert“. In dieser Studie wurde kein Betrieb in die beste Kategorie „exzellent“ und auch keiner in die schlechteste Kategorie "nicht klassifiziert" eingestuft. Dies entspricht auch weitestgehend den bisher durchgeführten Untersuchungen mit dem WQP auf anderen Milchviehbetrieben. So zeigten POSPESCU et al. (2014), dass alle von innen untersuchten Betriebe mit Laufställen und Anbindeställen auch nicht als „exzellent“ oder „nicht klassifiziert“ eingestuft wurden, sondern nur in eine der beiden mittleren Kategorien. In einer weiteren Studie von DE VRIES et al. (2013) wurde auch kein Betrieb mit „exzellent“ bewertet, ebenso wie bei ANDREASEN et al. (2013). Letztere bewerteten die meisten ihrer untersuchten Betriebe ebenfalls nur in den Kategorien „akzeptabel“ und „verbessert“ und nur einen von 43 Betrieben mit der Kategorie „nicht klassifiziert". Aufgrund von diesen internationalen Studien und der vorliegenden Arbeit, kann davon ausgegangen werden, dass die Anforderungen der Kategorie „exzellent“ sehr hoch sind und bisher nur wenige Milchviehbetriebe den hohen Welfare-Standards, wie sie im WQP vorgesehen sind, genügen. HEATH et al. (2014) griffen dieses Problem ebenfalls auf und empfahl vorzugsweise die Nutzung von einzelnen Indikatoren des WQP, unabhängig von den aggregierten Gesamtbewertungen. Diese seien aufgrund von bestimmten Gewichtungen der einzelnen Indikatoren nicht sensitiv genug um Betriebe insgesamt bewerten zu können.

BuRow et al. (2013a) verwendeten eine andere multidimensionale Untersuchungsmethode um Milchkühe hinsichtlich ihres Wohlbefindens bei Weidehaltung und ganzjähriger Stallhaltung zu untersuchen. Wie auch in dieser vorliegenden Arbeit, fanden BUROW et al. (2013a) ein verbessertes Tierwohl während der Sommermonate, im Vergleich zu den Wintermonaten. Zudem zeigten sie einen Zusammenhang zwischen gesteigertem Tierwohl und einem Anstieg der Anzahl von Weidestunden während der Weidesaison. Betrachtet man die Untersuchungen von CHARLTON et al. (2011) und MOTUPALLI et al. (2014), kann davon ausgegangen werden, dass die Weidehaltung im Sommer eine durchaus praktikable Möglichkeit darstellt das Wohlbefinden von hochleistenden Milchkühen zu verbessern, da diese eine eindeutige Präferenz für die Weide zeigten, wenn sie selbst zwischen Weide und Stall wählen konnten. 


\subsubsection{Fütterung und Körperkondition}

Verschiedene Studien haben jedoch auch bereits gezeigt, dass die Weidehaltung bei hochleistenden Milchkühen problematisch sein kann (KOLVER und MULLER, 1998; BARGO et al., 2002; WASHBURN et al., 2002; BRADE und FLACHOWSKY, 2005; FONTANELI et al., 2005; HeRnANDEZ-MENDO et al., 2007; KenNedy et al., 2008; AlAWNEH et al. ,2012; MEIKLE et al., 2013), da diese auf der Weide nicht genügend Futter aufnehmen oder nur Futter mit ungenügenden Nährstoffgehalten vorfinden. Dies führt bei vielen Tieren zu einer negativen Energiebilanz und die Tiere verlieren an Gewicht.

Wie auch in Kapitel 2.1 beschrieben, zeigten die Tiere aller untersuchten Gruppen dieser Arbeit in den Sommermonaten geringere Körperkonditionen, als in den Wintermonaten. BUROw et al. (2013a) stellten bei den von ihnen untersuchten Tieren mit Weidezugang ebenfalls eine geringere Körperkondition während der Weideperiode fest. Diese untersuchten in Dänemark 41 Milchviehbetriebe mit Liegeboxenlaufställen und Weidezugang für mindestens 120 Tage im Jahr und mindestens fünf Stunden täglich. In der vorliegenden Untersuchung zeigten insbesondere die Gruppen mit Weidezugang große Variationen der Körperkondition in den Sommer- und Wintermonaten.

Die genannten Probleme mit der Körperkondition sind nach STEINWIDDER und STARZ (2006) und THOMET et al. (2014) in erster Linie auf mangelhaftes Weidemanagement zurück zu führen und auch auf die Zuchtfortschritte der letzten Jahre, in denen die Holstein-Friesian Kühe schwerer wurden, mehr Milch produzieren können, aber der Verdauungstrakt nicht mehr auf variable Futtermengen und -qualitäten eingestellt ist. Demzufolge müsste eine Weidehaltung für hochleistende Milchkühe eine optimale Weidequalität bereitstellen und eine angepasste Zufütterung von Grundfutter oder TMR im Stall erfolgen. Aber auch mit diesen Voraussetzungen scheint es nach MULLER (2003) nur schwer möglich die Tiere bei einer bestimmten Körperkondition, auch während der Weidesaison, zu halten. Da in der vorliegenden Arbeit (Kapitel 2.1 und 2.3) auch die ganzjährig im Stall gehaltenen Kühe im Sommer deutlich an Körperkondition verloren, kann davon ausgegangen werden, dass auch der Hitzestress im Stall einen bedeutenden Einfluss auf den Verlust der Körperkondition hat. Nach STAPLES und THATCHER (2011) sind insbesondere Kühe in den ersten 50 Tagen der Laktation besonders sensibel gegenüber Hitzestress. Demnach sind bei diesen Tieren bereits $+1^{\circ} \mathrm{C}$ Körpertemperatur verantwortlich für etwa 15\% weniger Futteraufnahme. Kühe, die Hitzestress ausgesetzt sind, sind empfindlicher gegenüber Azidose Erkrankungen, da der ruminale $\mathrm{pH}$ Wert, aufgrund von verminderten Wiederkauaktivitäten durch den akuten Hitzestress, sinkt (STAPLES und THATCHER, 2011). Durch die verminderten Fettreserven bei geringer Körperkondition der Kuh, kann es auch zum Rückgang des Fettgewebes im Ballenpolster der Klaue kommen (RANDALL et al., 2015; WESTIN et al., 2016). Ein zu gering ausgeprägtes 
Ballenpolster kann das Lahmheitsrisiko der Kühe erhöhen, wie die Studien von RANDALL et al. (2015) und WESTIN et al. (2016) auch nachwiesen. In weiterführenden Studien über die Weidehaltung sollte die Körpertemperatur als Indikator bzw. Hitzestress als zusätzliches Kriterium für Tierwohl mit aufgenommen werden.

Die Körperkondition hat jedoch nicht nur Auswirkungen auf die Tiergesundheit, sondern kann auch aufgrund von mangelnden Fettreserven, zu weniger Milchleistung und verlängerten Rastzeiten führen (MULLER, 2003; KOHNEN, 2006). In den Untersuchungen von MULLER (2003) konnten auch mit hochwertigem Weidefutter und hohen Mengen Kraftfutter nur geringere Körperkonditionen der Tiere am Ende der Weidesaison gezeigt werden. Nach ROCHE et al. (2007) sollte insbesondere im Zeitraum des Abkalbens ein Body Condition Score von 3,5 (5-Punkte-Skala) angestrebt werden, da sonst mit einer geringeren Milchleistung in der folgenden Laktation zu rechnen ist.

\subsubsection{Integumentschäden und Erkrankungen}

Wie bereits HERNANDEZ-MENDO et al. (2007) und CORAZZIN et al. (2010) zeigten, wurde auch in dieser Arbeit (Kapitel 2.1) nachgewiesen, dass der Weidezugang in den Sommermonaten signifikant positive Effekte auf Lahmheiten sowie auf Tarsal- und Karpalverletzungen hatte. Begründungen hierfür könnten der dauerhaft weiche Untergrund sein auf dem die Tiere auf der Weide laufen und liegen können. Dadurch werden die Gelenke weniger belastet. Zudem ist mehr Platz pro Tier auf der Weide vorhanden, die Tiere können auf einem rutschfesten Untergrund laufen und haben so auch mehr Bewegungsfreiheit als im Stall. Vergleichbar mit dieser Arbeit, untersuchte BuROW et al. (2013b) Kühe mit drei bis neun Stunden und mit neun bis 21 Stunden Weidezugang sowie Kühe mit ganzjähriger Stallhaltung. Die Tiere mit weniger Stunden auf der Weide zeigten eine 2,2-mal geringere und die Tiere mit mehr Weidestunden eine 4,8-mal geringere Wahrscheinlichkeit von Integumentschäden, als die Tiere in ganzjähriger Stallhaltung. Kapitel 2.1 zeigte ebenfalls weniger Tiere mit haarlosen Stellen und Hautverletzungen mit zunehmender Anzahl der Stunden auf der Weide. Auch HASKELL et al. (2006) und RUTHERFORD et al. (2008) fanden mehr Karpal- und Tarsalgelenksverletzungen bei Kühen ohne Weidezugang, im Vergleich zu Kühen mit Weidezugang. WECHSLER et al. (2000) begründeten den Rückgang von Verletzungen während der Weidesaison damit, dass auf der Weide Kollisionen mit den Liegeboxen oder Stalleinrichtungen sowie eine Abrasion an den Tarsalgelenken durch Gummimatten in den Liegeboxen, nicht möglich seien.

Positive Effekte der Weidehaltung konnten auch für Mastitis Erkrankungen gezeigt werden (Kapitel 2.1 und 2.3). WHITE et al. (2002) zeigte ebenfalls, dass laktierende Kühe ohne Zugang zur Weide höhere Mastitis Prävalenzen aufwiesen als Kühe mit Weidezugang. Auch 
WASHBURN et al. (2002) wies nach, dass Kühe in ganzjähriger Stallhaltung 1,8-mal mehr klinische Mastitis Fälle zeigten als Kühe mit Weidezugang.

\subsection{Effekte des Weidezugangs auf Klauenparameter}

\subsubsection{Klauenhärte}

Im Rahmen der funktionellen Klauenpflege wird nach TOUSSAINT-RAVEN (1989) für gesunde Kühe, eine Dorsalwandlänge von 7,5 cm empfohlen. In der vorliegenden Arbeit (Kapitel 2.2) wurde jedoch für alle Weidegruppen eine mittlere Länge von $7,54 \mathrm{~cm}$ bis $8,58 \mathrm{~cm}$ gemessen, bevor die Klauenpflege vorgenommen wurde. Dementsprechend lagen alle Gruppen im Durchschnitt über diesem Schwellenwert von $7,5 \mathrm{~cm}$. Aktuelle Untersuchungen von ARCHER et al. (2015) zeigten aber auch, dass für adulte Holstein-Friesian Kühe eine Länge von mindestens $9 \mathrm{~cm}$ und für jüngere Tiere in der 1 . oder 2 . Laktation $8,5 \mathrm{~cm}$ empfohlen werden sollten. TOUSSAINT-RAVEN (1989) empfahl die Dorsalwandlänge von 7,5 cm vor mehr als 20 Jahren, seitdem sind Holstein-Friesian Kühe deutlich großrahmiger und schwerer geworden. Eventuell könnten für eine Anpassung der funktionellen Klauenpflege diesbezüglich weitere Untersuchungen durchgeführt werden.

\subsubsection{Klauenerkrankungen}

Die Klauenhärte ist für eine gesunde Klaue sehr wichtig, da weiche Klauen häufiger Läsionen aufweisen als harte Klauen (BORDERAS et al., 2004). Das unterstützt auch die Ergebnisse dieser Arbeit (Kapitel 2.2), die zeigt, dass verschiedene Klauenkrankheiten negativ mit der Klauenhärte korreliert sind. In dieser Arbeit (Kapitel 2.2) konnten für die Sohlenhärte keine Unterschiede, für die Härte der Sohlenwand jedoch signifikante Unterschiede zwischen den Weidegruppen festgestellt werden. BORDERAS et al. (2004) stellten heraus, dass es bisher noch nicht geklärt ist, ob Klauen aufgrund der entsprechenden Erkrankung weicher werden oder ob erst durch eine weiche Klaue die Erkrankung entstanden ist. Empfohlen wird von BORDERAS et al. (2004) eine Haltungsumwelt, in der eine Kuh die Möglichkeit hat ihre Klauen so trocken wie möglich zu halten, was einerseits mit Weidehaltung, andererseits auch mit gut gepflegten Tiefboxen realisiert werden kann. BERGSTEN et al. (2016) machten deutlich, dass die positiven Effekte der Weideperiode auf die Klauen nur durch ein gut geführtes Stallmanagement auch über den Winter hinweg beibehalten werden können. Demzufolge müssen die Laufgänge einen angemessenen Abrieb für die Klauen bieten, die Tiere müssen sich ausreichend bewegen können, Laufgänge und Liegeboxen müssen möglichst Kot- und Harn-frei gehalten werden, ein gewisser Hygienestandard muss eingehalten werden und die Klauenpflege muss regelmäßig von geschultem Personal durchgeführt werden. 
Sowohl BuRgStAlLER et al. (2016), als auch die vorliegende Arbeit (Kapitel 2.2) zeigten die Klauenerkrankungen BF, WLD und REHE als die Erkrankungen mit den höchsten Prävalenzen. Ergebnisse von LÓPEZ und PAMELA (2014), zeigten DD, DID kombiniert mit BF und REHE Erkrankungen als häufigste Erkrankungen und als solche Erkrankungen, die für junge Färsen mit Weidezugang eine deutlich geringere Prävalenz zeigten, als für gleichaltrige Färsen ohne Weidezugang. Wie auch in der vorliegenden Arbeit wurden von LóPEZ und PAMELA (2014) nur sehr geringe Prävalenzen von SG und LI gefunden. Die geringen Prävalenzen von WLD unterschieden sich dagegen sehr deutlich von denen in dieser Arbeit. Eine Begründung könnte darin liegen, dass die von LÓPEZ und PAMELA (2014) untersuchten Färsen deutlich jünger waren als der Durchschnitt der Tiere in der vorliegenden Studie. ROdRIGUEZ-LAINZ et al. (1999), WELLS et al. (1999) und HolZHAUER et al. (2006, 2012) fanden einen präventiven Effekt bezüglich weniger DD durch Weidezugang. LAVEN und LAWRENCE (2006) zeigten den Zusammenhang zwischen einer dreckigen und feuchten Klauenumgebung und einem darin begründeten Anstieg von DD Prävalenzen aufgrund von vermehrten Bakterien in Kot und Urin. Außerdem nehmen sie an, dass durch die angestiegene Prävalenz von DD Erkrankungen in den letzten Jahren, DD auch länger während der Weideperiode persistiert. In der vorliegenden Arbeit (Kapitel 2.2) zeigten die Weidegruppen mit mehr als sechs Stunden Weidezugang deutlich weniger schwere Fälle von DD während der Weidesaison. Damit könnte die Annahme von LAVEN und LAWRENCE (2006) unterstützt werden, dass die DD Erkrankungen während der Weidesaison nicht vollständig ausheilten, sondern sich in dieser Zeit nur in einem milderen oder inaktiven Stadium befanden.

Der Einfluss der Weide auf REHE Erkrankungen wurde in verschiedenen Studien unterschiedlich beurteilt. Nach HOLZHAUER et al. (2012) und den Ergebnissen dieser vorliegenden Arbeit (Kapitel 2.2) hatte der Weidezugang keinen Einfluss auf die Prävalenzen der REHE Erkrankungen, nach SOMERS et al. (2003) konnten hingegen signifikant mehr schwere REHE Erkrankungen bei Tieren ohne Weidezugang gefunden werden, im Vergleich zu Tieren mit Weidezugang.

BARKER et al. (2010) und HASKELL et al. (2006) zeigten, dass sich die Stallsaison aus verschiedenen Gründen negativ auf die Klauengesundheit auswirken kann, da beide Studien weniger lahme Tiere mit Weidezugang vorfanden, als ohne Weidezugang. Nicht angepasste Stalleinrichtungen, wie zu schmale Laufgänge und Liegeboxen, falsch eingestellte Nackenrohre und Sackgassen werden als häufige Risikofaktoren genannt, an denen sich die Tiere im Stall verletzen können (WESTIN et al., 2016). Aber auch die vielen Stunden am Tag, an denen die Tiere in Kot und Urin auf harten, betonierten Böden stehen müssen können sich, insbesondere während der Stallsaison, negativ auf die Klauengesundheit auswirken (ALGERS et al., 2009). MÜLLING und GREENOUGH (2006) empfehlen, aufgrund der langen Stehzeiten auf 
hartem Boden und den damit verbundenen Schädigungen des Gewebes und Muskelskelettsystems, keine ganzjährige Stallhaltung auf betoniertem Bodenmaterial.

\subsection{Effekte des Weidezugangs auf die Milchleistung und -inhaltsstoffe}

Wie bereits von REHN et al. (2000) und SMITH et al. (2013) beschrieben, zeigte auch diese Arbeit (Kapitel 2.1 und 2.3), dass insbesondere hochleistende Milchkühe ohne Weidezugang mehr Milch produzierten als Kühe mit Weidezugang. SMITH et al. (2013) begründeten diesen Rückgang der Milchleistung mit Hitzestress, dem die Tiere auf der Weide ausgesetzt waren. Diese Studie (Kapitel 2.3) sowie auch OETZEL (2007) zeigten ein deutliches Absinken der Milchleistung etwa ab dem Monat Juni für die zweite Jahreshälfte, bis zu einem Wiederanstieg im November. Dieser Rückgang kann zum einen durch Hitzestress oder auch durch die geringere Körperkondition im Sommer begründet werden (AVENDAÑO-REYES, 2012).

Fett und Eiweißgehalte der Milch unterschieden sich in der vorliegenden Arbeit nicht zwischen den Gruppen. Andere Ergebnisse zeigten jedoch O'CALLAGHAN et al. (2016), die für Kühe mit Weidezugang signifikant höhere Fett- und Eiweißgehalte feststellten, als für Kühe, die ganzjährig keinen Zugang zur Weide hatten. In der vorliegenden Arbeit, sowie auch bei BeRnABuccl et al. (2015), StAPLES und THATCHER (2011) und OETZEL (2007), zeigten sich jedoch Unterschiede bei den Fett- und Eiweißgehalten zwischen den Jahreszeiten. In der warmen Jahreszeit waren die Fett- und Eiweißgehalte deutlich geringer als in den Wintermonaten. In dieser Arbeit ging der Eiweißgehalt in den Sommermonaten um etwa 0,2 Prozentpunkte zurück, der Fettgehalt allerdings um etwa 0,4 Prozentpunkte. Durch dieses ungleiche Verhältnis erhöhte sich der Anteil von Kühen mit einem Fett-Eiweiß-Quotient $<1$. Mehr Tiere mit einem Fett-Eiweiß-Quotient < 1 zeigten sich insbesondere in den Gruppen mit Weidehaltung, was die Wahrscheinlichkeit in diesen Weidegruppen für Stoffwechselstress bei den Tieren erhöht (DECHOW et al. 2011).

In dieser Arbeit (Kapitel 2.3) zeigten sich nur geringe Unterschiede zwischen den Zellzahlen der Weidegruppen. Vergleichbare Ergebnisse fanden auch DECHOW et al. (2011) in ihren Untersuchungen von Milchkühen im Laufstall mit und ohne Weidezugang. In der vorliegenden Studie konnten jedoch signifikant häufiger Abgänge aufgrund von Mastitis Erkrankungen in der Gruppe mit ganzjähriger Stallhaltung festgestellt werden, im Vergleich zu den Gruppen mit Weidehaltung. Die Zellzahlen unterschieden sich in dieser Arbeit, wie auch bei BERNABUCCI et al. (2015) deutlich zwischen den Sommer und Wintermonaten. STAPLES und THATCHER (2011) sowie auch SMITH et al. (2013) zeigten, dass Kühe, die Hitzestress ausgesetzt wurden signifikant höhere Zellzahlen aufwiesen, als Kühe ohne Hitzestress. 


\subsection{Stalleinrichtung}

In dieser Arbeit zeigten nur 20 der 61 Betriebe, auf denen die Liegeboxen Maße ausgemessen wurden, die empfohlenen Längen und Breiten der Liegeboxen (LK NRW, 2012). Auch WESTIN et al. (2016) untersuchten 36 Milchviehbetriebe und fanden darunter nur einen Betrieb, der den Anforderungen an die Liegeboxenmaße entsprach. WESTIN et al. (2016) zeigte signifikante Korrelationen zwischen der optimalen Breite einer Liegebox und weniger Lahmheitsprävalenzen und betonte daher die Wichtigkeit der empfohlenen Liegeboxenmaße oder eine Selektion der Tiere, passend zu den jeweiligen Liegeboxen auf dem Betrieb.

Betriebe mit Hochboxen zeigten in dieser Arbeit (Kapitel 2.3) mehr schwer lahme Tiere als Betriebe mit Tiefboxen. WECHSLER et al. (2000), KANSWOHL und SANFTLEBEN (2006), ZÄHNER et al. (2009) und auch diese Studie zeigten, dass Tiere in Hochboxen, auch mit qualitativ hochwertigen Gummimatten, deutlich mehr Integumentschäden aufwiesen als in Tiefboxen. Auch in den Untersuchungen von VAN GASTELEN et al. (2011) und BRENNINKMEYER et al. (2013) konnten geringere Prävalenzen und Schweregrade von Tarsalgelenksverletzungen in Tiefboxen, anstelle von Hochboxen, festgestellt werden. Bezüglich der Klauengesundheit fanden BERGSTEN et al. (2016) vermehrt Ballenfäuleerkrankungen, Weiße Linie Defekte, Sohleneinblutungen und Sohlengeschwüre in Hochboxen im Vergleich zu Tiefboxen. BRENNINKMEYER et al. (2013) und BAK et al. (2016) empfahlen daher die Verwendung von Tiefboxen um Tarsalgelenksverletzungen und Lahmheiten vorzubeugen bzw. zu vermeiden.

Die Vorliegende Arbeit (Kapitel 2.3) untersuchte außerdem die Sauberkeit der Tiere im Unterschied zwischen Hoch- und Tiefboxen und zeigte, dass die Tiere in Tiefboxen weniger dreckige Flanken aufwiesen als in Hochboxen. Diese Ergebnisse finden sich auch bei KANSWOHL und SANFTLEBEN (2006), die ebenfalls deutlich mehr Tiere mit dreckigen Flanken in Hochboxen zeigten, trotz zusätzlichem Einstreu auf den Gummimatten der Hochboxen und zur Verfügung stehenden elektrischen Kuhbürsten. Die genannten Studien zeigen demnach verbesserte Gesundheitsparameter und einen höheren Liegekomfort in gut gepflegten Tiefboxen, als in Hochboxen.

In dieser Arbeit wurden zudem die Tier-Liegeplatz-Verhältnisse (TLV) und die Tier-FressplatzVerhältnisse (TFV) der einzelnen Betriebe untersucht (Kapitel 2.3). Hier zeigten sich bei einem niedrigen TLV (TLV $<1=$ mehr als ein Liegeplatz pro Tier) höhere Milchleistungen, geringere Abgangsraten, mehr Tiere mit geringeren Zellzahlen und weniger Tiere mit einem $F E Q<1$. Bei einem niedrigen TFV (TFV $<1=$ mehr als 1 Fressplatz pro Tier) konnten höhere Eiweiß-Gehalte in der Milch und geringere Harnstoffwerte festgestellt werden. Trotz der genannten Vorteile von niedrigen TLV und TFV hatten nur 29 von 60 Betrieben ein TLV $\leq 1$ und nur 25 von 60 Betrieben ein TFV $\leq 1$. 


\subsection{Zukunft der Weidehaltung}

Die bisher gezeigten Nachteile der Weidehaltung, wie ungenügende Energieaufnahme, dadurch bedingte schlechte Köperkondition, unregelmäßige Fütterung sowie Hitzestress in den Sommermonaten, könnten weitestgehend durch ein saisonales Abkalbesystem, nach irischem Vorbild, vermindert oder ganz vermieden werden (REIJS et al., 2013). Irische Milchkühe erbringen geringere Milchleistungen als Holstein-Friesian Kühe, sind aber genetisch vollständig der saisonalen Abkalbung angepasst. So haben alle Tieren während der Jahreszeit den Peak ihrer Laktationskurve in der auch für die Weide die besten Bedingungen bestehen um viel Energie zu liefern (COLEMAN et al., 2009). Nach REIJS et al. (2013) ist es für viele Milchviehhalter jedoch einfacher und kontrollierbarer ganzjährig das gleiche Management in Fütterung und Haltung beizubehalten, weshalb die Tiere immer häufiger auch im Sommer in Ställen gehalten werden. So kann die Fütterung zwar immer gleichmäßig erfolgen, es ist aber auch ganzjährig mit mehr Arbeit durch die benötigte Futtervorlage, die Reinigung der Liegeboxen und der Laufgänge verbunden, was bei Weidehaltung deutlich seltener nötig wäre. Um sich auf die Weidehaltung zu spezialisieren, lagern Milchviehhalter mittlerweile viele Feldarbeiten an Lohnunternehmen aus und integrieren automatische Melksysteme immer häufiger in die Weidehaltung. Durch automatische Separations-Tore können die Tiere immer erst nach dem Besuch des Melkroboters auf die Weide bzw. werden gleich nach Eintritt in den Stall zum Melkroboter geleitet. Fortschritte, um noch effektivere Weidehaltung betreiben zu können, gibt es auch in den Bereichen der Wettervorhersagen und der technischen Hilfestellungen um Nährstoffgehalte der Weide zukünftig besser einschätzen zu können (REIJS et al., 2013).

THOMET et al. (2014) beschrieben den für die Weidehaltung geeigneten Kuhtyp für eine zukünftige, ressourceneffiziente Milchproduktion. Die von ihnen Untersuchten Vollweidebetriebe hatten ihren Kuhtyp dahingehend angepasst, indem sie die Genetik größtenteils aus Neuseeland importierten und damit die Holstein-Friesian durch New Zealand Holstein-Friesian und Kiwi-Cross verdrängten. Diese Rassen sind für die Weidehaltung sehr gut geeignet, da sie aus dem betriebseigenen Grundfutter am meisten Milch produzieren können (DELABY et al., 2009; 2010; HAIGER und KNAUS 2010). Diese ressourceneffizienten Rassen können sich an das variable Angebot des Weidefutters anpassen, da sie eine entsprechend hohe Stoffwechselstabilität aufweisen (STEINWIDDER und STARZ, 2006). Durch diese Stoffwechselstabilität und die mittlere Milchleistung dieser Rassen können die Tiere auch eine längere Nutzungsdauer erreichen (THOMET et al., 2014). Nach INEICHEN et al. (2014) ist aber nicht nur die Anpassung der Zucht an das Vollweidesystem eine Bedingung für den Erfolg einer weidebasierten Milchproduktion, sondern ist auch das Weidemanagement von großer Bedeutung. So muss die Grashöhe regelmäßig erfasst werden um indirekt die Qualität der 
Flächen zu bestimmen. Danach muss wiederum eine Zuteilung der Herde zu den qualitativ passenden Flächen erfolgten. Außerdem ist eine dem Standort angepasste Düngung durchzuführen sowie die Lenkung der Bestandszusammensetzung durch Nachsaaten. STEINWIDDER und STARZ (2006) betonen auch, dass das geringere Körpergewicht von Milchkuhrassen mit mittlerer Milchleistung, aufgrund von weniger Trittschäden, eher für die Weidehaltung geeignet ist.

Weiterhin wird auch die Herdengröße ein bestehendes Hemmnis für die Weidehaltung bleiben. Es sind zu wenig arrondierte Flächen vorhanden, als dass den stetig wachsenden Herden noch ausreichend Weide- bzw. angemessene Futterflächen zur Verfügung stehen könnten (REIJs et al. 2013; LEISEN, 2014).

Milchviehhalter müssen im internationalen Markt wettbewerbsfähig bleiben und für viele Betriebe ist es daher ein großer Unsicherheitsfaktor die Weide in ihr System als günstige Futterquelle mit einzubeziehen, dafür aber weniger Milch erzeugen zu können (REIJS et al., 2013). Bei gegebenen Standortvoraussetzungen kann eine weidebasierte low-cost Strategie in der Milcherzeugung aber durchaus wirtschaftlich sein, wie bereits mehrere Untersuchungen gezeigt haben (u.a. DILLON et al., 2005; STEINWIDDER et al., 2010; KIEFER, 2014). Insbesondere bei den vorhergesagten volatilen und hohen Preisen für konservierte Futtermittel und Energie, ist die Weidehaltung jedoch auch in Zukunft noch gleichermaßen wirtschaftlich (REIJS et al., 2013). Auf geeigneten Grünlandstandorten könnte daher eine „Weidemilch“ als Vermarktungskonzept realisiert werden. Dieses Wertschöpfungspotential von einem Produkt mit „Weidemilch“ kann aber nur ermöglicht werden, wenn auch der Verbraucher einen Mehrwert in der Weidehaltung erkennt und bereit ist höhere Produktpreise zu zahlen (WEIß, 2014).

In Deutschland werden bereits von einigen Molkereien Anreize zur Weidehaltung geschaffen, indem Prämien für die Milch an den Landwirt gezahlt werden, wenn die Kühe Weidezugang für eine bestimmte Stundenanzahl pro Tag und Tagesanzahl pro Jahr erhalten. Dem zunehmenden Trend zur ganzjährigen Stallhaltung könnte durch weitere Anreize aus Industrie und Forschung zur Steigerung des Grünlandertrags oder mit zielgerichteten staatlichen Maßnahmen entgegengewirkt werden (REIJS et al., 2013).

\subsection{Literatur}

Alawneh, J.I., M.A. Stevenson, N.B. Williamson, N. Lopez-Villalobos und T. Otley (2012): The effect of liveweight change on reproductive performance in a seasonally calving, pasture fed dairy herd. Livestock Science 145,131-139.

Algers, B., G. Bertoni, D. Broom, J. Hartung, L. Lidfors, J. Metz, L. Munksgaard, T.N. Pina, P. Oltenacu, J. Rehage und J. Rushen (2009): Scientific report on the effects of farming 
systems on dairy cow welfare and disease. Report of the Panel on Animal Health and Welfare. Annex to the EFSA Journal 1143, 114-284.Andreasen, S., F. Wemelsfelder, P. Sandøe und B. Forkman (2013): The correlation of Qualitative Behavior Assessments with Welfare Quality® protocol outcomes in on-farm welfare assessment of dairy cattle. Applied Animal Behaviour Science 143, 9-17.

Andreasen, S., F. Wemelsfelder, P. Sandøe und B. Forkman (2013): The correlation of Qualitative Behavior Assessments with Welfare Quality ${ }^{\circledR}$ protocol outcomes in on-farm welfare assessment of dairy cattle. Applied Animal Behaviour Science 143, 9-17.

Archer, S.C., R. Newsome, H. Dibble, C.J. Sturrock, M.G.G. Chagunda, C.S. Mason und J.N. Huxley (2015): Claw length recommendations for dairy cow foot trimming. Veterinary Record 177, 222.

Avendaño-Reyes, L. (2012): Heat stress management for milk production in arid zones, milk production - an up-to-date overview of animal nutrition, management and health. Narongsak Chaiyabutr (Ed.), InTech.

Bak, A.S., M.S. Herskin und M.B. Jensen (2016): Effect of sand and rubber surface on the lying behavior of lame dairy cows in hospital pens. Journal of Dairy Science 99(4), 28752883.

Bargo, F., L.D. Muller, J.E. Delahoy, und T.W. Cassidy (2002): Performance of high producing dairy cows with three different feeding systems combining pasture and total mixed rations. Journal of Dairy Science 85, 2948-2963.

Barker, Z.E., K.A. Leach, H.R. Whay, N.J. Bell und D.C.J. Main (2010): Assessment of lameness prevalence and associated risk factors in dairy herds in England and Wales. Journal of Dairy Science 93, 932-941.

Bergsten, C., E. Telezhenko und M. Ventorp (2016): Influence of soft or hard floors before and after first calving on dairy heifers locomotion, claw and leg health. Animals 5, 662-668.

Bernabucci, U., L. Basiricò, P. Morera, D. Dipasquale, A. Vitali, F. Piccioli Cappelli und L. Calamari (2015): Effect of summer season on milk protein fractions in Holstein cows. Journal of Dairy Science 98 (3), 1815-1827.

Borderas, T.F., B. Pawluczuk, A.M. De Passillé und J. Rushen (2004): Claw Hardness of Dairy Cows: Relationship to Water Content and Claw Lesions. Journal of Dairy Science 87, 2085-2093.

Brade, W. und G. Flachowsky (eds.) (2005): Rinderzucht und Milcherzeugung: Empfehlungen für die Praxis. Bundesforschungsanstalt für Landwirtschaft (FAL), Braunschweig. Landbauforschung Völkenrode Sonderheft 289, 125-126.

Brenninkmeyer, C., S. Dippel, J. Brinkmann, S. March, C. Winckler und U. Knierim (2013): Hock lesion epidemiology in cubicle housed dairy cows across two breeds, farming systems and countries. Preventive Veterinary Medicine 109, 236-245. 
Burgstaller, J., J. Raith, S. Kuchling, V. Mandl, A. Hund und J. Kofler (2016): Claw health and prevalence of lameness in cows from compost bedded and cubicle freestall dairy barns in Austria. The Veterinary Journal 216, 81-86.

Burow, E., T. Rousing, P.T.N. Thomsen, D. Otten und J.T. Sørensen (2013a): Effect of grazing on the cow welfare of dairy herds evaluated by a multidimensional welfare index. Animal 7, 834-842.

Burow, E., P.T. Thomsen, T. Rousing und J.T. Sørensen (2013b): Daily grazing time as a risk factor for alterations at the hock joint integument in dairy cows. Animal 7, 160-166.

Charlton, G.L., S.M. Rutter, M. East und L.A. Sinclair (2011): Preference of dairy cows: Indoor cubicle housing with access to a total mixed ration vs. access to pasture. Applied Animal Behaviour Science 130(1), 1-9.

Coleman, J., K.M. Pierce, D.P. Berry, A. Brennan und B. Horan (2009): The influence of genetic selection and feed system on the reproductive performance of spring-calving dairy cows within future pasture-based production systems. Journal of Dairy Science, 92, 5258-5269.

Corazzin, M., E. Piasentier, S. Dovier und S. Bovolenta (2010): Effect of summer grazing on welfare of dairy cows reared in mountain tie-stall barns. Italian Journal of Animal Science 9, 304-312.

De Vries, M., E.A.M. Bokkers, G. van Schaik, R. Boltreau, B. Engel, T. Dijkstra und I.J.M. de Boer (2013): Evaluating results of the Welfare Quality multi-criteria evaluation model for classification of dairy cattle welfare at the herd level. Journal of Dairy Science 96, 1-10.

Dechow, C.D., E.A. Smith und R.C. Goodling (2011): The effect of management system on mortality and other welfare indicators in Pennsylvania dairy herds. Animal Welfare, 20: 145-158.

Delaby, L., P. Faverdin, G. Michel, C. Disenhaus und J.L. Peyraud (2009): Effect of different feeding strategies on lactation performance of Holstein and Normande dairy cows. Animal 3, 891-905.

Delaby, L., B. Horan, M.O. Donovan, Y. Gallard und J.L. Peyraud (2010): Are high genetic merit dairy cows compatible with low input grazing systems? In: „Grassland Science in Europe“, Tagungsband des 23. Hauptversammlung der European Grassland Federation, Kiel, Deutschland, 928-930.

Dillon, P., J.R. Roche, L. Shalloo und B. Horan (2005): Optimising financial returns from grazing in temperate pastures. Utilisation of Grazed Grass in Temperate Animal Systems. Tagungsband: international Grassland Congress, Cork, Ireland. Wageningen Academic Publishers, Wageningen, Niederlande, 131-147. 
Fontaneli, R.S., L.E. Sollenberger, R.C. Littell und C.R. Staples (2005): Performance of lactating dairy cows managed on pasture-based or in freestall barn-feeding systems. Journal of Dairy Science 88, 1264-1276.

Gieseke, D., C. Lambertz, I. Traulsen, J. Krieter und M. Gauly (2014): Beurteilung von Tiergerechtheit in der Milchviehhaltung - Evaluierung des Welfare Quality® Protokolls. Züchtungskunde 86, 58-70.

Haiger, A. und W. Knaus (2010): Vergleich von Fleckvieh und Holstein Friesian in der Milch und Fleischleistung. Milchleistungsvergleich ohne Kraftfutter. Züchtungskunde 82, 131143.

Haskell, M.J., L.J. Rennie, V.A. Bowell, M.J. Bell and A.B. Lawrence (2006): Housing system, milk production, and zero-grazing effects on lameness and leg injury in dairy cows. Journal of Dairy Science 89, 4259-4266.

Hernandez-Mendo, O., M.A.G von Keyserlingk, D.M. Veira und D.M. Weary (2007): Effects of pasture on lameness in dairy cows. Journal of Dairy Science 90, 1209-1214.

Heath, C.A.E., Y. Lin, S. Mullan, W.J. Browne und D.C.J. Main (2014): Implementing Welfare Quality® in UK assurance schemes: evaluating the challenges. Animal Welfare 23, 95107.

Holzhauer, M., C. Hardenberg, C.J.M. Bartels und K. Frankena (2006): Herd- and cow-level prevalence of digital dermatitis in the Netherlands and associated risk factors. Journal of Dairy Science 89, 580-588.

Holzhauer, M., B. Brummelman, K. Frankena und T.J.G.M Lam (2012): A longitudinal study into the effect of grazing on claw disorders in female calves and young dairy cows. The Veterinary Journal 193, 633-638.

Ineichen, S. und P. Thomet (2014): Milchproduktion mit Wiesenfutter als alleinige Futtergrundlage: Futterbau- und Herdenmanagement eines Vollweidebetriebes. Grasland- und weidebasierte Milchproduktion, Mitteilungen der Arbeitsgemeinschaft Grünland und Futterbau Band 16, Internationale Weidetagung, Zollikofen, Schweiz (Hrsg. Reidy B, B. Gregis und P. Thomet), 128-131.

Kanswohl, N. und P. Sanftleben (2006): Analyse und Bewertung von Hoch- und Tiefboxen für Milchrinder aus arbeitswirtschaftlicher, ethologischer, hygienischer und ökonomischer Sicht. http://www.landwirtschaft-

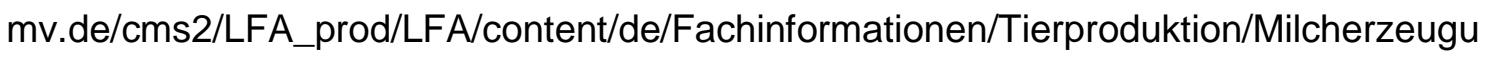
ng/FoBericht_HochTierfboxen/FB_Hoch_Tiefboxen_Kanswohl.pdf. Accessed January 09, 2017.

Kennedy, E., M. O'Donovan, L. Delaby und F.P. O'Mara (2008): Effect of herbage allowance and concentrate supplementation on dry matter intake, milk production and energy balance of early lactating dairy cows. Livestock Science 117, 275-286. 
Kiefer, L. (2014): Gesamtbetriebliche Analyse von Weidebetrieben und Weidesystemen in der Milchviehhaltung in unterschiedlichen Regionen Süddeutschlands. Dissertation. Universität Hohenheim.

Kohnen, H. (2006): Einfluss der Weide auf den Laktationsverlauf und die Tiergesundheit. In: Tagungsband Internationale Weidetagung, Aulendorf 11.-13. September 2006, 1-21.

Kolver, E.S. und L.D. Muller (1998): Performance and nutrient intake of high producing Holstein cows consuming pasture or a total mixed ration. Journal of Dairy Science 81, $140-1411$.

Laven, R.A. und K.R. Lawrence (2006): An evaluation of the seasonality of veterinary treatments for lameness in UK dairy cattle. Journal of Dairy Science, 89, 3858-3865.

LK NRW (2012): NRW Bauschrift Milchviehhaltung - Beratungsempfehlungen für den Bau und die Ausstattung von Milchviehställen. Landwirtschaftskammer NRW, Referat 24 Energie, Bauen, Technik, Münster.

López, M. und E. Pamela (2014): Effect of grazing, calving and disease history on severity of claw lesions in Dutch young dairy cattle.

http://repositorio.educacionsuperior.gob.ec/bitstream/28000/1457/1/T-SENESCYT00590.pdf. Accessed January 08, 2017.

Meikle, A., M.D.L. Adrien, D.A. Mattiauda und P. Chilibroste (2013): Effect of sward condition on metabolic endocrinology during the early postpartum period in primiparous grazing dairy cows and its association with productive and reproductive performance. Animal Feed Science and Technology 186, 139-147.

Motupalli, P.R., L.A. Sinclair, G.L. Charlton, E.C. Bleach und S.M. Rutter (2014): Preference and behavior of lactating dairy cows given free access to pasture at two herbage masses and two distances. Journal of Animal Science 92(11), 5175-5184.

Muller, L.D. (2003): Pasture, body condition and reproduction. Proceedings of conference Nutrition of dairy cows on pasture-based systems, 31.03.2003, Grantville, Pennsylvania, United States, 79-81.

Mülling, C.H. und P.R. Greenough (2006): Applied Physiopathology of the Foot. http://www.ivis.org/proceedings/wbc/wbc2006/mulling.pdf?LA=1. Abgerufen am 23. Januar 2017.

O'Callaghan, T.F., D. Hennessy, S. McAuliffe, K.N. Kilcawley, M. O'Donovan, P. Dillon, R.P. Ross und C. Stanton (2016): Effect of pasture versus indoor feeding systems on raw milk composition and quality over an entire lactation. Journal of Dairy Science 99 (12), 9424 9440.

Oetzel, G.R. (2007): Subacute Ruminal Acidosis in Dairy Herds: Physiology, Pathophysiology, Milk Fat Responses, and Nutritional Management. 40. Jahrestagung der „American Association of bovine practitioners", 17. September, 2007, Vancouver, Canada. 
Popescu, S., C. Borda, E.A. Diugan, M. Niculae, S. Razvan und C.D. Sandru (2014): The effect of the housing system on the welfare quality of dairy cows. Italian Journal of Animal Science 13, 15-22.

Randall L.V., M. J. Green, M.G.G. Chagunda, C. Mason, S.C. Archer, L.E. Green, und J.N. Huxley (2015): Low body condition predisposes cattle to lameness: An 8-year study of one dairy herd. Journal of Dairy Science 98, 3766-3777.

Rehn, H., B. Berglund, U. Emanuelsson, G. Tengroth und J. Philipsson (2000): Milk production in Swedish dairy cows managed for calving intervals of 12 and 15 months. Animal Science 50, 263-271.

Reijs J, C. Daatselaar, J. Helming, J. Jager und A. Beldman (2013): Grazing dairy cows in north-west Europe. LEI Report 2013-001. LEI Wageningen UR, Den Haag, Niederlande.

Roche, J.R., J.M. Lee, K.A. Macdonald und D.P. Berry (2007): Relationships Among Body Condition Score, Body Weight, and Milk Production Variables in Pasture-Based Dairy Cows. Journal of Dairy Science 90, 3802-3815.

Rodriguez-Lainz, A., P. Melendez-Retamal, D.W. Hird, D.H. Read und R.L. Walker (1999): Farm- and host-level risk factors for papillomatous digital dermatitis in Chilean dairy cattle. Preventive Veterinary Medicine 42, 87-97.

Rutherford, K.M.D., F.M. Langford, M.C. Sherwood, L. Jack, A.B. Lawrence und M.J. Haskell (2008): Hock injury prevalence and associated risk factors on organic and nonorganic dairy farms in the United Kingdom. Journal of Dairy Science 91, 2265-2274.

Smith, D.L., T. Smith, B.J. Rude und S.H. Ward (2013): Short communication: Comparison of the effects of heat stress on milk and component yields and somatic cell score in Holstein and Jersey cows. Journal of Dairy Science 96, 3028-3033.

Somers, J., K. Frankena, E.N. Noordhuizen-Stassen und J.H.M. Metz (2003): Prevalence of claw disorders in Dutch dairy cows exposed to several floor systems. Journal of Dairy Science 86, 2082-2093.

Staples, C.R. und W.W. Thatcher (2011): Stress in Dairy Animals - Heat Stress: Effects on Milk Production and Composition. Food Science, Encyclopedia of Dairy Sciences, 561566.

Steinwidder, A. und W. Starz (2006): Sind unsere Kühe für die Weide noch geeignet? Tagungsband der "Freiland-Tagung", September 2006, Veterinärmedizinische Universität Wien, Österreich, 37-43.

Steinwidder, A., W. Starz, L. Podstatzky, L. Kirner, E.M. Pötsch, R. Pfister, und M. Gallenböck (2010): Low-Input Vollweidehaltung von Milchkühen im Berggebiet Österreichs Ergebnisse von Pilotbetrieben bei der Betriebsumstellung. Züchtungskunde 82, 241252. 
Thomet, P., S. Ineichen und H. Jörg (2014): Züchten von Kühen für eine effiziente graslandbasierte Milchproduktion. Grasland- und weidebasierte Milchproduktion, Mitteilungen der Arbeitsgemeinschaft Grünland und Futterbau Band 16, Internationale Weidetagung, Zollikofen, Schweiz (Hrsg. Reidy B, B. Gregis und P. Thomet), 61-70.

Toussaint-Raven, E. (1989): Cattle foot care and claw trimming. Farming Press, Ipswich, UK. 14-20.

Van Gastelen, S., B. Westerlaan, D.J. Houwers und F.J.C.M. van Eerdenburg (2011): A study on cow comfort and risk for lameness and mastitis in relation to different types of bedding materials. Journal of Dairy Science 94 (10), 4878-4888.

Washburn, S.P., S.L. White, J.T.Jr. Green und G.A. Benson (2002): Reproduction, mastitis, and body condition of seasonally calved Holstein and Jersey cows in confinement or pasture systems. Journal of Dairy Science 85, 105-111.

Wechsler, B., J. Schaub, K. Friedli und R. Hauser (2000): Behaviour and leg injuries in dairy cows kept in cubicle systems with straw bedding or soft lying mats. Applied Animal Behaviour Science 69, 189-197.

Weiß, D. (2014): Imagewirkung von weidenden Kühen. In: Grasland- und weidebasierte Milchproduktion, Mitteilungen der Arbeitsgemeinschaft Grünland und Futterbau Band 16, Internationale Weidetagung, Zollikofen, Schweiz (Hrsg. B. Reidy, B. Gregis und P. Thomet), 98-101.

Welfare Quality (2012): Welfare Quality® assessment protocol for cattle applied to dairy cows. Welfare Quality $\AA^{B}$ Consortium, Lelystad, Niederlande.

Wells, S.J., L.P. Garber und B.A. Wagner (1999): Papillomatous digital dermatitis and associated risk factors in U.S. dairy herds. Preventive Veterinary Medicine 38, 11-24.

Westin, R.A. Vaughan, A.M. de Passillé, T.J. DeVries, E.A. Pajor, D. Pellerin, J.M. Siegford, A. Witaifi, E. Vasseur und J. Rushen (2016): Cow- and far-level resk factors for lameness on dairy farms with automated milking systems. Journal of Dairy Science 99 (5), 373243.

Zähner, M., S. Schrade, W. Schaeren und J. Schmidtko (2009): "Wiederkäuer: Haltung und Gesundheit: Neue Materialien als Einstreu in Liegeboxen von Milchviehställen" Proceedings of the conference 10. science conference organic farming, 11.-13.02.2009, ETH Zurich, Switzerland, 50-53. 


\section{Danksagung}

Zunächst möchte ich mich bei meinem Doktorvater Prof. Dr. Dr. Matthias Gauly ganz besonders bedanken für das allzeit entgegen gebrachte Vertrauen in meine Arbeit, das freundliche, kollegiale Miteinander und für die fachliche Unterstützung, die ich sehr geschätzt habe.

Zudem danke ich auch Prof. Dr. Imke Traulsen und Prof. Dr. Johannes Isselstein für die Übernahme des 2. und 3. Korreferates.

Vielen Dank auch dem Niedersächsischen Ministerium für Wissenschaft und Kultur für die Finanzierung des Projektes „Systemanalyse Milch“ in dessen Rahmen ich meine Untersuchungen durchführen und meine Dissertation bearbeiten konnte. Außerdem bedanke ich mich sehr bei den Betriebsleitern der Milchviehbetriebe und den Klauenpflegern für ihre Offenheit und Unterstützung bei meiner Datenerhebung auf ihren Betrieben. Insbesondere auch nochmal ein Dankeschön an Dr. Hans-Peter Klindworth für die ausführliche, praktische Weiterbildung in allen Fragen der Klauengesundheit.

Dr. Christian Lambertz möchte ich ganz herzlich für die fachliche Betreuung danken, für die jederzeit gute und freundschaftliche Kommunikation und die Hilfestellungen für die Anfertigung meiner Arbeit auch über mehrere Ländergrenzen hinweg.

Danke natürlich auch an Daniel Gieseke, der mich in der theoretischen und praktischen Durchführung des Welfare Quality Protokolls während vieler Stallbesuche und Diskussionsrunden ausführlich geschult hat.

Für die Unterstützung bei sämtlichen fachlichen und organisatorischen Fragen während meiner Promotionszeit sowie für die moralische Unterstützung auf vielen Tagungen, bedanke ich mich auch noch sehr herzlich bei Henning Schaak, Hinrich Schulte, Sarah Kühl, Stefanie Ammer, Sophie Meyer-Hamme, Anna Stölzl, Katharina Stanzel, Birgit Sohnrey, Erwin Tönges und Burchhard Möllers.

Meiner Familie, meinen Freunden und ganz besonders meinem Mann möchte ich für die moralische und organisatorische Unterstützung während der letzten Jahre danken. 


\section{Eidesstattliche Erklärung}

1. Hiermit erkläre ich, dass diese Arbeit weder in gleicher noch in ähnlicher Form bereits anderen Prüfungsbehörden vorgelegen hat.

Weiter erkläre ich, dass ich mich an keiner anderen Hochschule um einen Doktorgrad beworben habe.

Göttingen, den

(Unterschrift)

2. Hiermit erkläre ich eidesstattlich, dass diese Dissertation selbständig und ohne unerlaubte Hilfe angefertigt wurde.

Göttingen, den

(Unterschrift) 


\section{Lebenslauf}

Linda Armbrecht, M.Sc. agr.

Dorfstraße 9a, 37127 Niemetal

linda.armbrecht@agr.uni-goettingen.de

Geschlecht: weiblich | Geburtsdatum: 21.11.1985 | Nationalität: Deutsch

\section{Ausbildung}

Seit 02/2014 Doktorandin, Georg-August-Universität Göttingen, Department für Nutztierwissenschaften, Produktionssysteme der Nutztiere, Verbundprojekt zur Weiterentwicklung der Milchviehhaltung in Niedersachsen - Systemanalyse Milch (http://www.systemanalysemilch.de/)

03/2014 Grundkurs Klauenpflege für den eigenen Bestand, Landwirtschaftskammer Niedersachsen, Landwirtschaftliches Bildungszentrum (LBZ) Echem

10/2011-01/2014 Masterstudium Agrarwissenschaften (M.Sc.) an der Technischen Universität München/ Campus Weihenstephan, Titel der Masterarbeit: „Einsatz moderner Lichttechnik zur Steigerung des Wohlbefindens und der Leistung bei Milchkühen“

04/2006 - 06/2009 Bachelorstudium Betriebswirtschaftslehre (B.Sc.) an der GeorgAugust-Universität Göttingen, Titel der Bachelorarbeit:

„Prozessanalyse und Produktentwicklung in der Serienfertigung“

\section{Universitäre Tätigkeiten}

Seit $01 / 2016$

Arbeitsgemeinschaft Milchwirtschaft, Organisation der Arbeitsgruppe, Georg-August-Universität Göttingen (http://www.unigoettingen.de/de/sh/26072.html)

Seit 05/2014 Beratendes Mitglied des Projekts „Weideland Norddeutschland“ Niedersächsisches Ministerium für Ernährung, Landwirtschaft und Verbraucherschutz (http://www.weideland.gruenlandzentrum.org/) 


\section{Praktische Erfahrungen}

10/2013 - 12/2013 Praktikum Herdenmanagement im Milchviehbetrieb LMG e.G. Greven Kälberversorgung, Melken, Frischmelker-Management, Fütterung, Klauenpflege

10/2012 - 09/2013 Praktikum bei der bayerischen Landesanstalt für Landwirtschaft/ Bereich Tier und Technik in Poing/ Grub - Durchführung, Dokumentation und Auswertung von Forschungsprojekten im Bereich Milchvieh und Legehennen

03/2012 - 08/2012 Aushilfskraft bei der bayerischen Landesanstalt für Landwirtschaft/ Institut für Ernährung und Markt in München - Datenrecherche und statistische Auswertungen, Erstellung der Schriftenreihe „Agrarmärkte“

04/2011 - 07/2011 Praktikantin bei der bayerischen Landesanstalt für Landwirtschaft/ Bereich Ökonomik Tier in München - Neukonzeption Deckungsbeitragskalkulation, Mitwirkung bei Betriebszweigabrechnungen und beim Projekt „Stärkung der Wettbewerbsfähigkeit der ökologischen Ferkelerzeugung in Bayern“

03/2010 - 02/2011 Projektleiterin bei der Maschinenringe Deutschland GmbH in Neuburg an der Donau - Weiterentwicklung des Projekts „Rohstoffabsicherung in der Landwirtschaft“, Kundenakquise mittels Roadshow und Messeauftritt „EuroTier“

09/2009 - 03/2010 Praktikantin im John Deere Werk Bruchsal/ Abteilung Qualitätssicherung - Überarbeitung der Qualitätsdokumente der John Deere Werke Mannheim und Bruchsal, Erstellung und Vorstellung von Schulungspräsentationen

\section{Konferenzbeiträge}

Schulte, H.D., Armbrecht, L., Bürger, R., Gauly, M., Musshoff, O. und Hüttel, S. (2017): Pasture-access of dairy cows: farm animal welfare at costs of technical efficiency? 57. Jahrestagung der GEWISOLA 2017 und 27. Jahrestagung der ÖGA 2017: Agrar- und Ernährungswirtschaft zwischen Ressourceneffizienz und gesellschaftlichen Erwartungen. 13.-15.09.2017, Technische Universität München/ Weihenstephan

Armbrecht, L., Lambertz, C., Albers, D. und Gauly, M. (2016): Auswirkungen des Weidegangs auf die Klauengesundheit von Milchkühen. Gemeinschaftstagung der DGfZ und GfT am 20.-21.09.2016 in Hannover. 
Armbrecht, L., Lambertz, C., Albers, D. und Gauly, M. (2016): Does access to pasture affect welfare in dairy cows?. 67th Annual Meeting of the European Federation of Animal Science (EAAP), 29.08.-02.09.2016, Belfast, Ireland.

Armbrecht, L., Lambertz, C., Albers, D. und Gauly, M. (2015): Tierwohl von Milchkühen bei Stall- und Weidehaltung - Ein Vergleich anhand des Welfare Quality® Protokolls.

Tagung "Tierhaltung im Spannungsfeld von Tierwohl, Ökonomie und Gesellschaft" am 07.- 08.10.2015 in Göttingen.

Armbrecht, L., Lambertz, C., Albers, D. und Gauly, M. (2015): Tierwohl von Milchkühen bei Stall- und Weidehaltung - Ein Vergleich anhand des Welfare Quality® Protokolls. Gemeinschaftstagung der DGfZ und GfT am 16.-17.09.2015 in Berlin.

Linda Armbrecht 